Universidad de Lima

Facultad de Comunicaciones

Carrera de Psicología

\title{
SALOMÓN: DETECCIÓN TEMPRANA EN TDAH
}

Tesis para optar por la licenciatura en Psicología

\author{
Mariana Morales Garbin
}

Código 20070721

Asesor

Elizabeth Irene Rojas Huamancaja

Lima- Perú

Diciembre 2015 


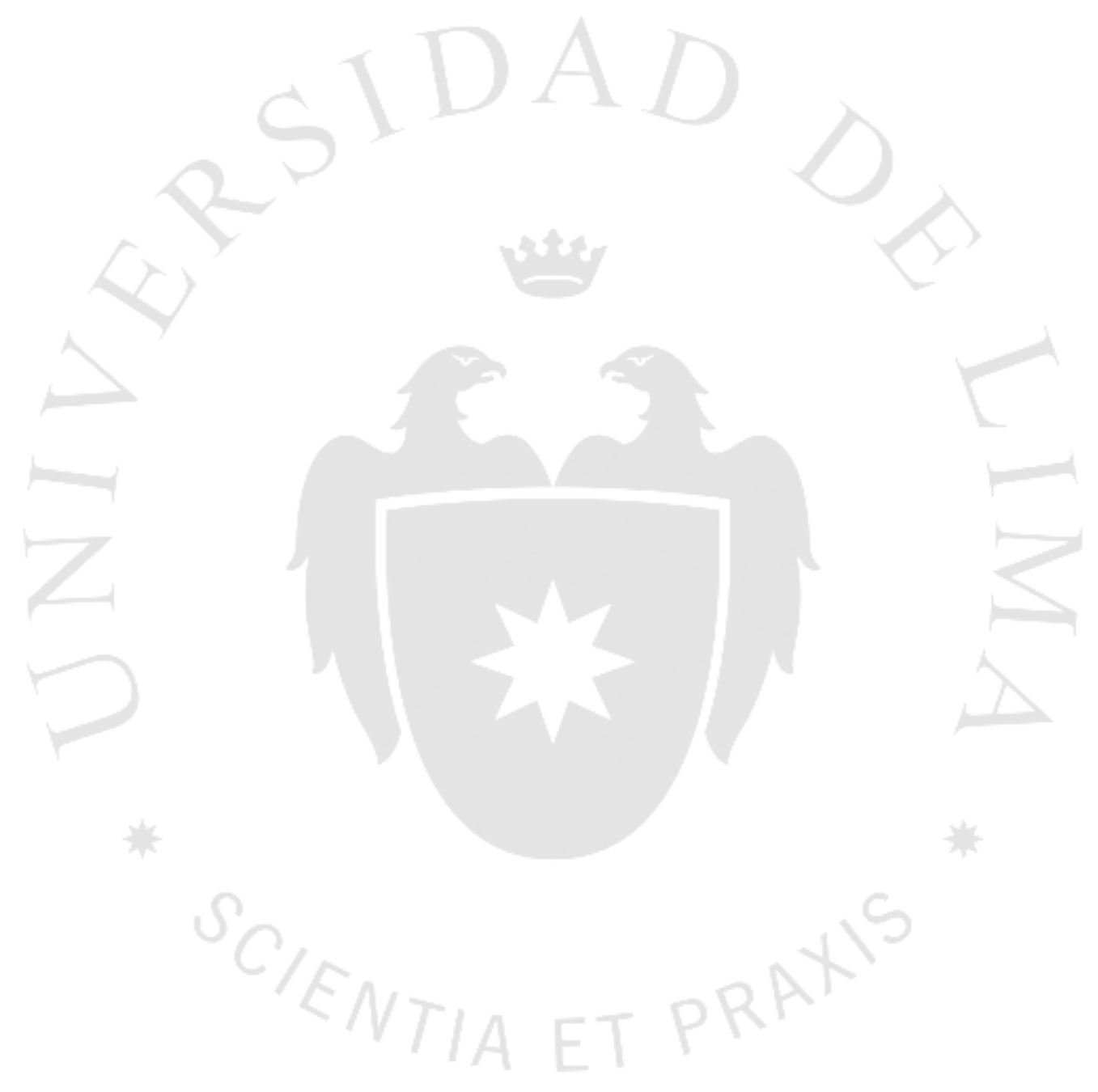


SALOMÓN: DETECCIÓN TEMPRANA EN TDAH 


\section{İNDICE DE CONTENIDO}

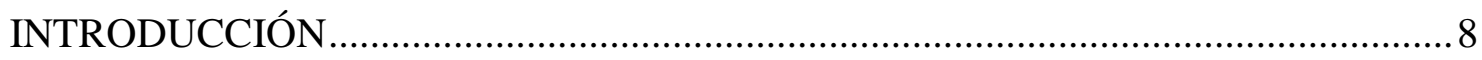

CAPÍTULO I. PLANTEAMIENTO DEL PROBLEMA............................................. 9

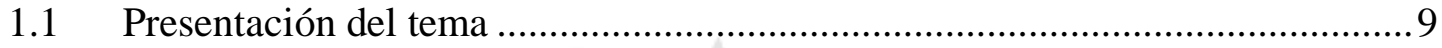

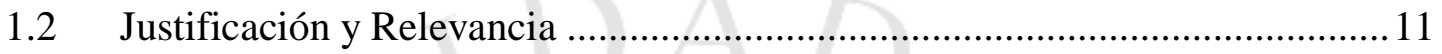

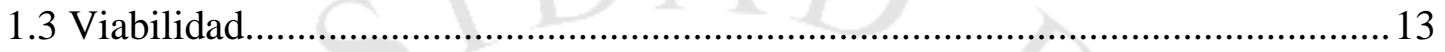

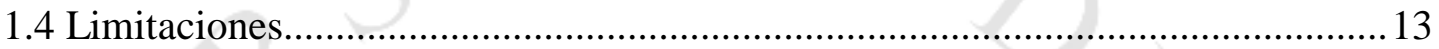

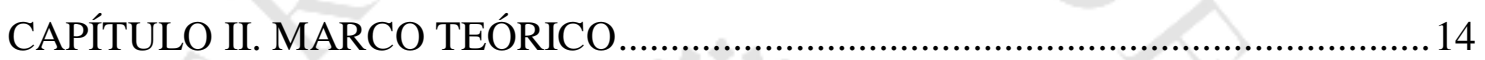

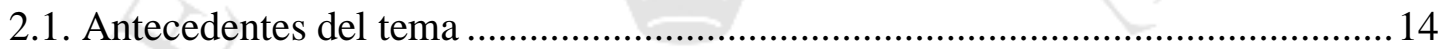

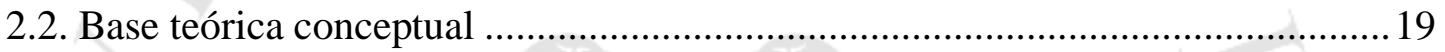

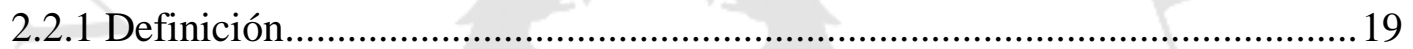

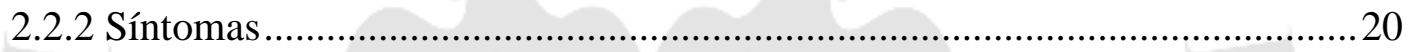

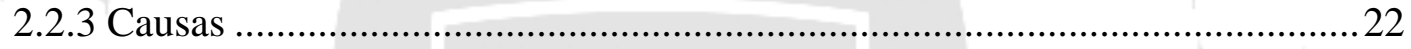

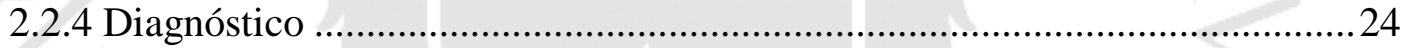

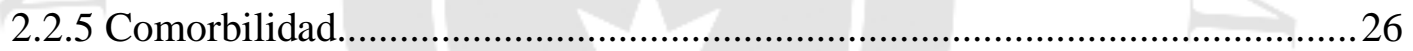

2.2.6 Diagnóstico diferencial: Asperger- TDAH ...................................................28

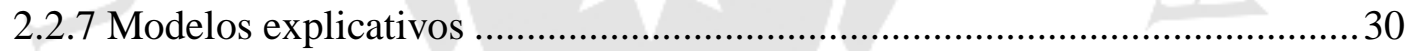

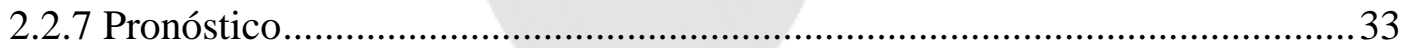

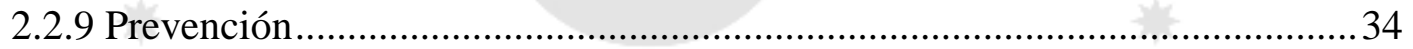

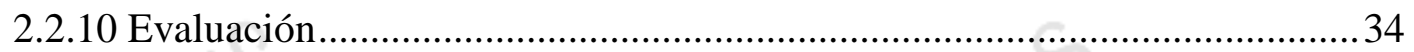

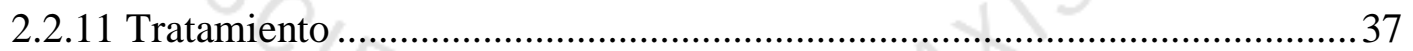

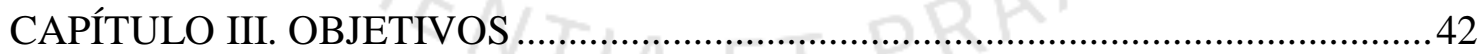

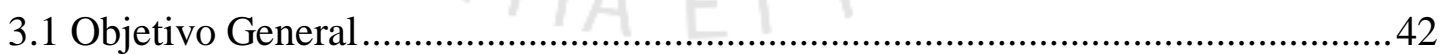

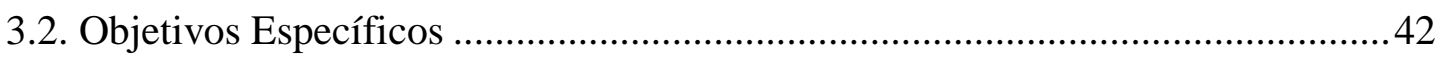

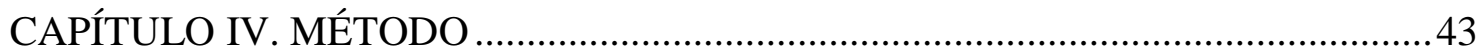

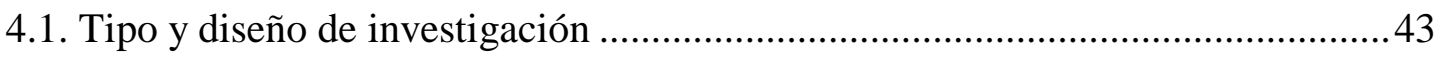

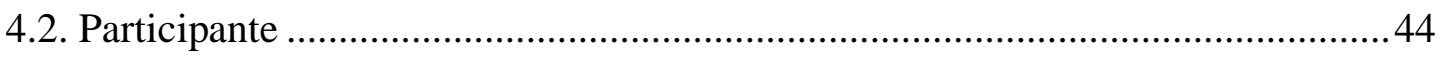

4.3. Técnicas de recolección de información........................................................... 44

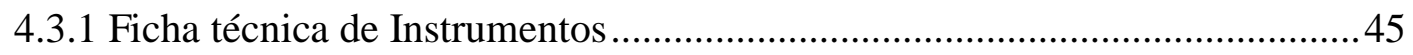

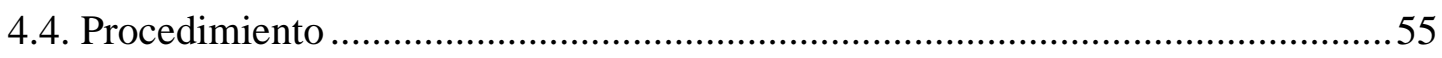




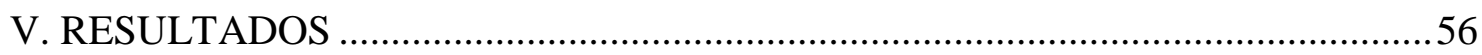

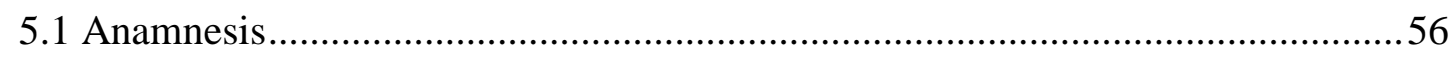

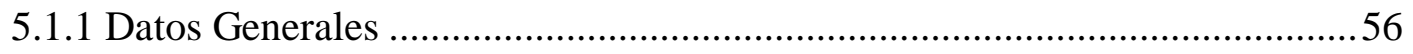

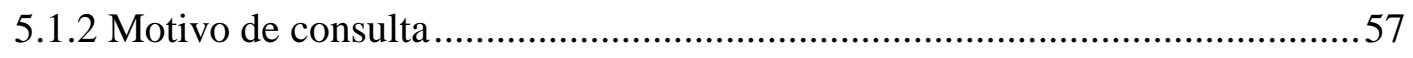

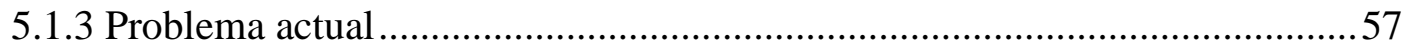

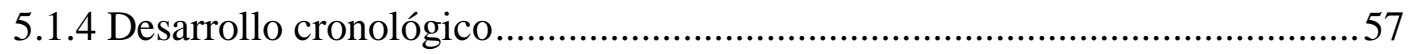

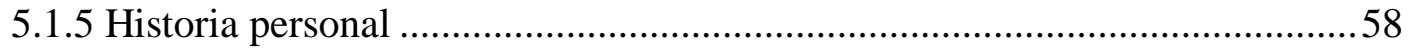

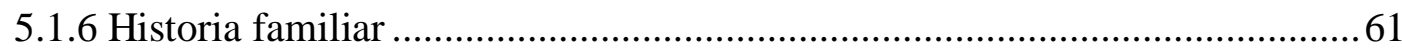

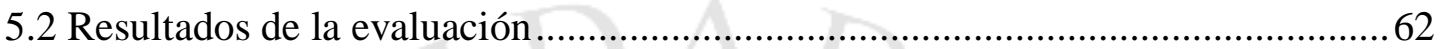

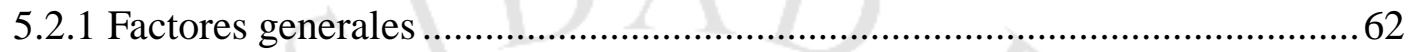

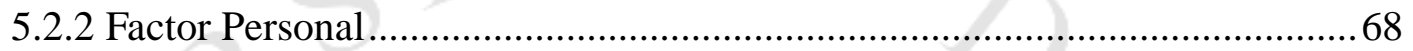

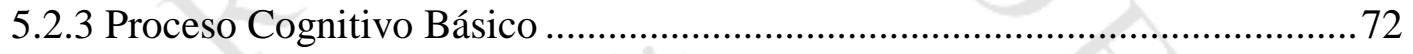

5.2.4 Factor Cognitivo Global...........................................................................

5.2.5 Factor Cognitivo Básico: Evalúa ………………………………………….....

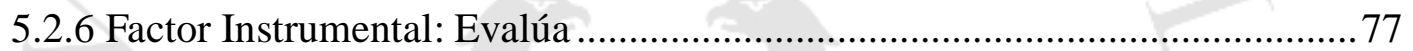

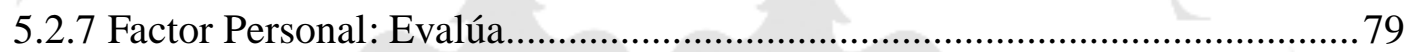

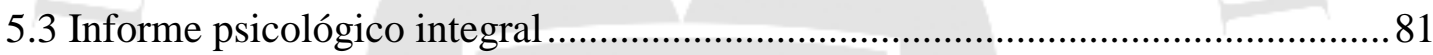

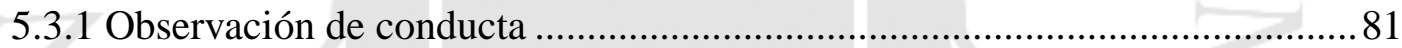

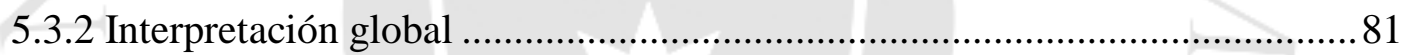

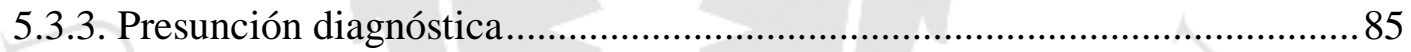

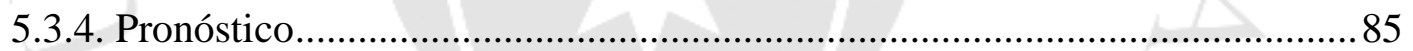

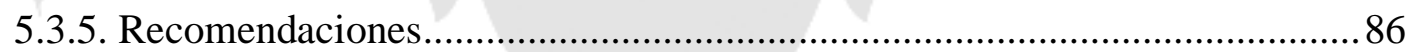

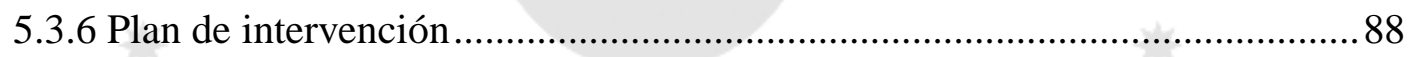

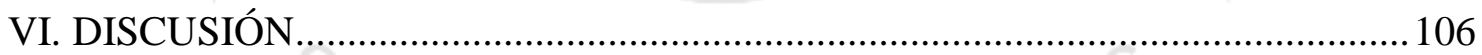

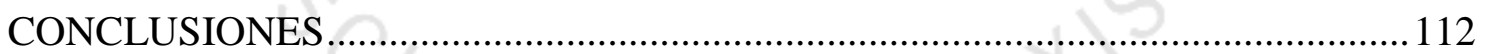

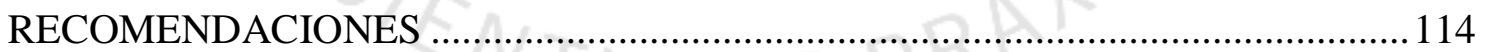

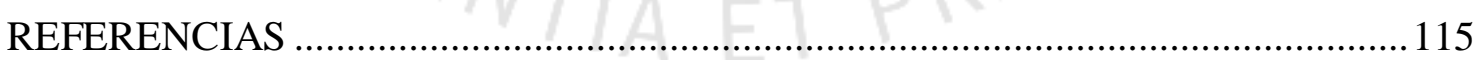

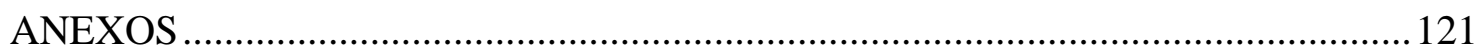




\section{ÍNDICE DE TABLA}

Tabla 2. 1: Diagnóstico del TDAH basado en el DSM-5 ...........................................24

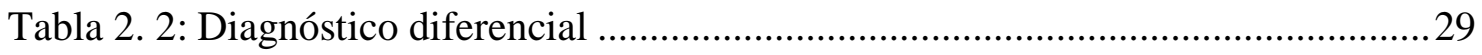

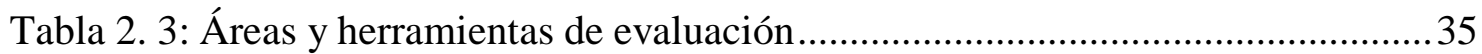

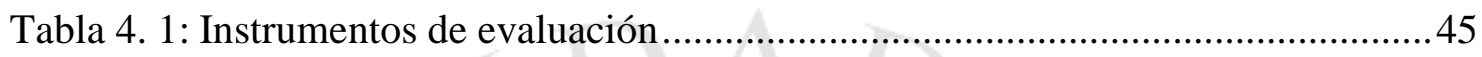

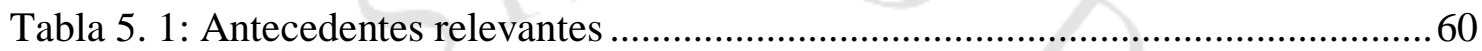

Tabla 5. 2: Resultados CI, Puntuaciones compuestas .............................................63

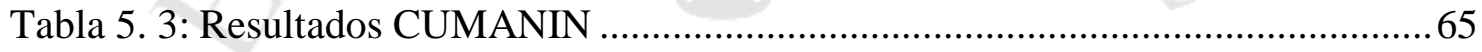

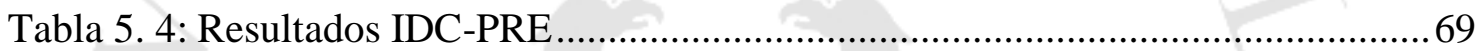

Tabla 5. 5: Categorías según puntajes ................................................................. 72

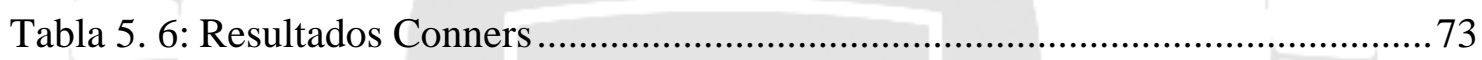

Tabla 5. 7: Resultados factor cognitivo global Evalúa-0 ............................................75

Tabla 5. 8: Resultados factor cognitivo básico Evalúa-0 …......................................... 77

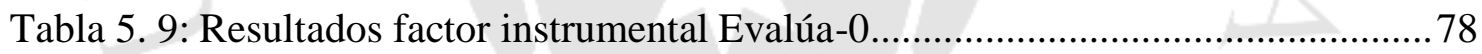

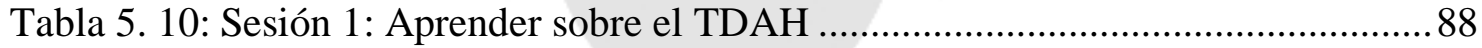

Tabla 5. 11: Sesión 2: Ayudarlo a identificar el TDAH en él ......................................89

Tabla 5. 12: Sesión 3: Aprender los pasos para realizar una tarea ................................91

Tabla 5. 13: Sesión 4: Recordar y ejecutar los pasos para realizar una tarea.................92

Tabla 5. 14: Sesión 5: Reforzar la selección y ejecución de pasos ................................93

Tabla 5. 15: Sesión 6: Reforzar el pensamiento inferencia y categorización..................95

Tabla 5. 16: Sesión 7: Reforzar la solución de problemas inferenciales.........................96

Tabla 5. 17: Sesión 8: Trabajar en la flexibilidad cognitiva..........................................98

Tabla 5. 18: Sesión 9: Reforzar la flexibilidad cognitiva .............................................99

Tabla 5. 19: Sesión 10: Entrenamiento en solución de problemas...............................101

Tabla 5. 20: Sesión 11: Entrenamiento en resolución de problemas.............................102 


\section{ÍNDICE DE FIGURA}

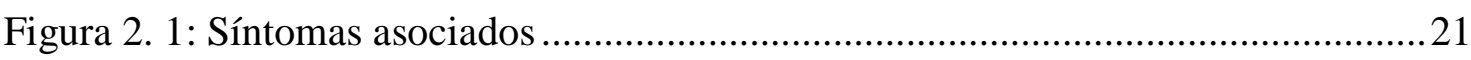

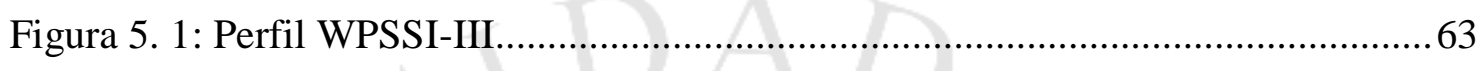

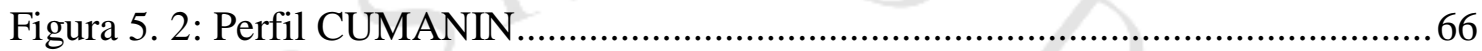

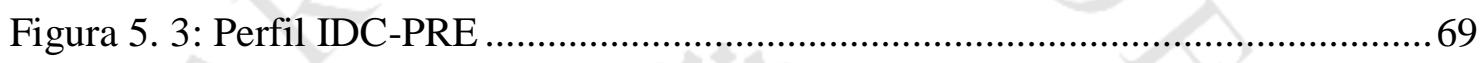

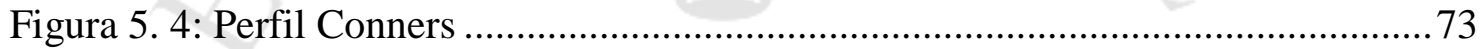

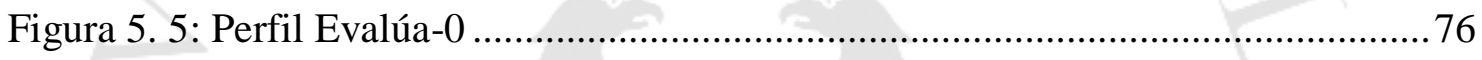




\section{INTRODUCCIÓN}

El Trastorno de Déficit de Atención e Hiperactividad (TDAH) es uno de los padecimientos neuropsiquiátricos más frecuentes a nivel mundial, impactando de manera importante a nivel conductual, de aprendizaje, así como en la adaptación del individuo en su entorno social.

Muchas veces los niños con TDAH se frustran al darse cuenta que no pueden controlarse o trabajar como les gustaría, comparándose con otros niños, teniendo como consecuencia otros trastornos o dificultades. Es por esto que es mejor una intervención temprana para anticiparse a futuras dificultades y brindar al niño las herramientas necesarias para desenvolverse de forma autónoma y eficaz.

A través de este estudio de caso se tuvo como objetivo principal reconocer la importancia del manejo de estrategias de detección temprana para realizar una intervención acorde a las necesidades del niño, buscando describir las características específicas y las consecuencias a nivel académico y social, definiendo los tratamientos y beneficios de un abordaje psicológico adecuado en el caso de un niño en etapa pre-escolar con Trastorno de Déficit de Atención e Hiperactividad. 


\section{CAPÍTULO I. PLANTEAMIENTO DEL PROBLEMA}

\subsection{Presentación del tema}

El Trastorno por Déficit de Atención e Hiperactividad (TDAH) es el trastorno neuropsiquiátrico más común en niños a nivel mundial y se caracteriza por grados variables y crónicos de inatención, hiperactividad e impulsividad, impactando de manera importante en el aprendizaje y rendimiento escolar, así como en la adaptación del individuo en su entorno social, lo que persiste en su vida adulta (Velarde, 2012). Dependiendo de los síntomas predominantes, se establecen de tres subtipos: primariamente inatento (TDAH-I), primariamente hiperactivo (TDAH-H) y combinado (TDAH-C). A partir de las investigaciones realizadas por Rodríguez (Madrid, 2009), el subtipo más frecuente es TDAH-I y secundariamente TDAH-C. Esta situación normalmente se invierte en población clínica y recientemente sucede lo mismo en algunos estudios de prevalencia sobre TDAH, donde el subtipo TDAH-C es el más frecuente. Esto puede deberse a que el TDAH-C implica mayores dificultades en la vida del niño, lo que ocasiona que necesite de apoyo terapéutico y exista un mayor número de casos clínicos registrados.

El trastorno por déficit atención con hiperactividad es uno de los padecimientos neuropsiquiátricos más frecuentes en niños, adolescentes y adultos, afectando al 5.2\% de la población mundial (De la Peña, 2009). Según investigaciones americanas, el 50\% de los niños con TDAH necesitan tutoría académica y el $30 \%$ repiten el año, requieren 
educación especial y no logran culminar la secundaria. Según Velarde (2012), en el Perú este trastorno tiene una comorbilidad del $5 \%$ en población infantil. Este es un problema que se presenta mayormente en niños, en una proporción variable de hombre - mujer de 4 a 1, según estadísticas que se maneja en el Instituto Nacional de Ciencias Neurológicas (INCN).

Los pacientes con TDAH generalmente tienen parientes hasta en tres generaciones con: incapacidad de aprendizaje, enfermedades afectivas (manía, depresión), alcoholismo, drogas, histeria, sociopatías, trastornos del pensamiento o narcolepsia.

El TDAH es un trastorno común en la actualidad. La mayoría de los niños o adolescentes que lo presentan, tienen además trastornos comórbidos. En esta situaciones el diagnóstico diferencial es mucho más difícil y el tratamiento más complicado. El diagnóstico comórbido más común es el trastorno negativista desafiante, que puede afectar hasta el $60 \%$ de niños o niñas con TDAH, derivado de esto, un $20 \%$ de esta población puede desarrollar el trastorno disocial (Pliszka, 2006).

Con respecto a las cifras de prevalencia para los trastornos del estado de ánimo y ansiedad, estas son menos precisas. Según investigaciones de Pliszka (2009), al menos un tercio de los niños con TDAH puede desarrollar un trastorno de ansiedad y de 10 a $30 \%$ puede desarrollar un trastorno depresivo mayor. Las cifras para la prevalencia de manía en niños con TDAH son algo más difíciles de determinar. Biederman y sus colaboradores (1999) encontraron que hasta el 16\% de su muestra de niños con TDAH cumplía con los criterios para manía.

El TDAH es un trastorno que, en mayor o menor grado, persiste a lo largo de toda la vida. Cuando no es tratado se considera que sólo en un 10-20\% de los casos existe ausencia de manifestaciones del trastorno con repercusión en la vida del individuo (Biederman 2005). Según distintos estudios, un $75 \%$ de niños con TDAH serán adolescentes con TDAH y, de estos adolescentes, un $50 \%$ serán adultos con TDAH (Wilens, 2004). La prevalencia del TDAH en la población adulta se calcula entre el 3-4 $\%$.

Aproximadamente un $20 \%$ de niños TDAH serán adultos con sintomatología grave (Wilens, 2004). Es por ello que el tratamiento durante la infancia es muy importante 
para la prevención de los problemas secundarios, especialmente los derivados del fracaso escolar, baja autoestima y marginalidad social.

Según Piñedo y Benito (2011), existen estudios que evidencian un menor nivel de educación y mayores tasas de desempleo, y más separados o divorciados entre los pacientes con TDAH. Un dato desalentador de estudio es que solo un $10 \%$ de los pacientes fue tratado durante el año previo.

"Es conocida la asociación entre el TDAH no tratado en la infancia con el desarrollo de un trastorno antisocial de personalidad en la edad adulta, sobre todo si predomina la clínica del trastorno impulsividad/hiperactividad y se asocian trastornos de conducta, lo que aumenta la posibilidad de realización de actos delictivos." (Piñeiro y Benito, 2011)

"Se detecta una alta prevalencia de TDAH infantil entre poblaciones de presos, con un rango que oscila entre el 31 y el 67\%, manteniéndose los síntomas en edad adulta en considerable proporción." (Piñeiro y Benito, 2011)

Derivado de esto, resulta de suma importancia que un niño con sospecha de TDAH reciba una intervención psicológica preventiva para que tenga un desarrollo académico y emocional adecuado y no repercuta en su vida adulta. Entonces surge la siguiente pregunta: ¿Qué estrategias de intervención son pertinentes para la detección temprana de niños pre-escolares con TDAH?

\subsection{Justificación y Relevancia}

El estudio de un caso de TDAH en un niño pre-escolar tiene como objetivo reconocer la importancia del manejo de estrategias de detección temprana para realizar una intervención acorde a las necesidades del niño.

En muchos casos, el contar con un déficit de atención tan marcado, se confunden los síntomas del trastorno del neurodesarrollo con trastorno no verbal, trastorno de aprendizaje, trastorno de conducta, entre otros, resultando en un tratamiento poco efectivo y adecuado al caso. 
Existe una gran diferencia entre un TDAH adulto, adolescente y niño, por lo cual es importante establecer un plan de trabajo teniendo en cuenta la etapa del desarrollo en la que se encuentra el niño y las principales áreas afectadas.

Por otro lado, la mayoría de veces, los niños con TDAH se frustran al darse cuenta que no pueden controlarse o trabajar como les gustaría, comparándose con otros niños, teniendo como consecuencia otros trastornos o dificultades, como es el caso de una pobre psicomotricidad, bajo rendimiento académico o problemas de conducta.

Por esto es importante identificar si el niño presenta los síntomas del TDAH para determinar si tiene o no el trastorno. Además, se debe determinar la dificultad principal para que el tratamiento sea efectivo. En este caso, se debe combinar una serie de estrategias y técnicas adaptándolas al caso.

Es mejor una intervención temprana para anticiparse a futuras dificultades y brindar al niño las herramientas necesarias para desenvolverse de forma autónoma y eficaz. De lo contrario, esto puede derivarse en problemas de autoestima y autoeficacia en la adolescencia, o abuso de drogas e incumplimiento de las leyes.

Es por ello importante realizar el diagnóstico temprano del TDAH, durante la etapa preescolar, por las dificultades que ello conlleva en la vida futura de estos niños en los ámbitos académicos, conductuales y sociales, especialmente en el subtipo combinado. Solo una intervención con medicación, en los casos más complejos de los preescolares, y un adecuado apoyo terapéutico y psicopedagógico posibilitan mediante una intervención combinada multidisciplinar, un mejor pronóstico para estos niños y sus familias (Mulas, 2012). Su diagnóstico precoz predice la afectación, y las correlaciones clínicas y los déficits neuropsicológicos con el TDAH escolar (Sonuga-Barque, 2002).

El presente estudio será de utilidad tanto para el área clínica como educativa, ya que en ambas se debe trabajar en conjunto para ayudar al niño y contribuir a su mejora. A partir de las evidencias encontradas, se podrá brindar las herramientas necesarias para favorecer una adecuada integración en su medio. Ya que en ocasiones este tipo de casos necesitan de mayor flexibilidad y una estructura clara para desarrollar su potencial. 


\subsection{Viabilidad}

El presente estudio de caso es posible debido a la frecuencia de niños y adolescentes diagnosticados con TDAH que asisten a una institución especializada en esa área.

La institución donde acude el niño en mención, cuenta con una biblioteca especializada tanto de pruebas psicológicas como de libros disponibles para los psicólogos, siendo la inversión mínima.

Además, se cuenta con el apoyo de un equipo interdisciplinario del centro, brindando la asesoría correspondiente.

Asimismo, se ha logrado, desde el inicio, el compromiso de la familia del niño, habiendo ya firmado el consentimiento para iniciar el estudio de caso.

\subsection{Limitaciones}

Una de las posibles limitaciones para el presente estudio es la suspensión por parte de los padres de familia de las citas programadas para concluir las evaluaciones y sesiones de terapia con el paciente.

Otra limitación es la no colaboración de los padres y del colegio durante el trascurso de la intervención. 


\section{CAPÍTULO II. MARCO TEÓRICO}

\subsection{Antecedentes del tema}

Miranda y colaboradores (2002) realizaron un estudio sobre la eficacia de una intervención psicosocial en niños con TDAH. Se propusieron dos objetivos, por una parte, analizar la eficacia de un programa psicosocial con múltiples componentes (programa de intervención en el aula) en 50 niños con TDAH de una forma individualizada empleando la metodología del análisis del cambio clínico significativo de Jacobson y Truax (1991). Por otra, tratar de delimitar las posibles variables moduladoras cognitivas y conductuales que pueden influir en los resultados de éxito/fracaso del programa. Se obtuvo como resultados que el 69,3\% de los niños con TDAH presentó una mejora importante y sólo un 30,7\% no presentaron cambios significativos después de la aplicación del programa. Atendiendo al primer objetivo, se puede concluir que aquellos niños con TDAH que presentan graves trastornos del comportamiento son los que peor respuesta tendrán en las intervenciones conductuales y los que necesitarán la administración de medicación. Los resultados obtenidos con respecto al segundo objetivo indican que las posibles variables que se encuentran modulando la eficacia de la intervención son los déficit en control inhibitorio así como los problemas de ansiedad, el oposicionismo, el aislamiento y la desadaptación social.

A partir de estas consideraciones resulta evidente que el entrenamiento de los profesores en técnicas cognitivas y conductuales, para optimizar la instrucción y manejar 
el comportamiento de los niños con TDAH, constituye un componente esencial en la planificación de intervenciones con una alta probabilidad de éxito.

Solovieva, Lázaro y Quintanar (2008), proponen la relación entre el TDA y la debilidad funcional de los lóbulos frontales. Con este fin, realizaron un estudio para comparar el estado funcional de los lóbulos frontales entre niños preescolares diagnosticados con TDA de zonas urbanas y niños preescolares normales de zonas rurales y urbanas. En el estudio participaron 36 niños con ausencia del trastorno (20 de zonas rurales y 16 de zonas urbanas) y 14 diagnosticados con TDA. Todos fueron evaluados con el "Esquema de Evaluación Neuropsicológica Infantil Breve", el cual incluye tareas para el análisis de los factores de programación y control y la organización motora secuencial, que permiten valorar el estado funcional de los sectores frontales. Los resultados en los niños de zonas rurales y con TDAH fueron similares. En cambio, se observaron diferencias significativas entre estos dos grupos y los niños de zonas urbanas. Los niños con TDA y de zonas rurales mostraron limitaciones en todas las actividades propuestas, especialmente en las tareas de copia y continuación de la secuencia gráfica y del juego verbal asociativo. Los resultados se analizaron en términos de las diferencias observadas entre los niños con TDA y los niños de zonas rurales, tanto cuantitativa como cualitativamente. Se llegó a la conclusión que existe una debilidad funcional de los lóbulos frontales en la población rural y en niños con TDA. Los resultados permiten suponer que el tipo de organización de la actividad del niño puede producir esta dificultad.

Según Papapzian, Alfonso y Araguez (2009), los escolares con TDAH-C presentan alteraciones en las funciones ejecutivas que mejoran mediante la administración de metilfenidato o con el entrenamiento de la memoria de trabajo. Debido a esto, se propuso como objetivo de investigación determinar el efecto del entrenamiento de las funciones ejecutivas sobre sus alteraciones y sobre el TDAH-C en preescolares. Se utilizó una distribución aleatoria en niños de 2 a 4 años de edad, afectados de TDAHC, con examen neurológico normal, sin enfermedades crónicas, que no estaban recibiendo tratamiento farmacológico a largo plazo y cuyos padres estaban de acuerdo en entrenar o no entrenar a sus hijos. Los padres completaron el cuestionario del DSMIV para identificar si sus hijos presentaban o no TDAH-C y las funciones ejecutivas se evaluaron mediante la "Dimensional Change Card Sort Task" en la primera evaluación 
y una vez al año durante tres años. El promedio de puntuación de la inatención, hiperactividad/impulsividad y funciones ejecutivas en los grupos entrenado o no entrenado, se analizaron estadísticamente mediante la t de Student. De 25 niños, 13 recibieron entrenamiento. Se obtuvo como resultado que la incidencia de TDAH-C descendió a 16 casos (64\%), de los cuales 6 niños (24\%) se encontraban en entrenamiento y 10 niños (40\%) sin él. El grado de mejora de la inatención, de la hiperactividad/impulsividad $\mathrm{y}$ de las funciones ejecutivas fue notorio con el entrenamiento de las funciones ejecutivas durante uno, dos y tres años. Finalmente se llegó a la conclusión, que con el fin de mejorar su condición, los niños preescolares con TDAH-C y alteraciones de las funciones ejecutivas deberían recibir entrenamiento de éstas durante, como mínimo, tres años desde el momento de su diagnóstico.

Palacios y colaboradores (2009) realizaron una investigación orientada a integrar la literatura reciente sobre el manejo clínico del TDAH en preescolares con el fin de actualizar los últimos algoritmos latinoamericanos de tratamiento e incorporar las medidas psicosociales dentro de las estrategias a utilizar. Para esto se integró un panel de expertos con seis especialistas de diferentes áreas: psiquiatría infantil y de la adolescencia, neuropediatría, psicología y neuropsicología de cinco países latinoamericanos. Los cuales revisaron la literatura de entre 2006 y 2008, elaborando el algoritmo de tratamiento de preescolares con TDAH, de acuerdo con las necesidades de la población latinoamericana. A partir de la información obtenida, los especialistas propusieron las principales recomendaciones para evaluar y manejar el TDAH en preescolares y construyeron un árbol de decisiones según el nivel de evidencia científica de cada propuesta de tratamiento. El resultado fue un algoritmo multimodal para el tratamiento de preescolares latinoamericanos con TDAH que plantea como primer recurso el manejo psicosocial y luego el tratamiento farmacológico. Se recomienda específicamente los tratamientos psicosociales como la psicoeducación, el entrenamiento en Manejo Parental (EMP) y la Terapia Interaccional Padre-Hijo (TIPH). La recomendación del metilfenidato como primera etapa farmacológica, seguido de la atomoxetina o las anfetaminas; en el último término se puede considerar el uso de clonidina. Se llegó a la conclusión que el algoritmo para preescolares latinoamericanos con TDAH recomienda el uso conjunto y racional de tratamientos farmacológicos y psicosociales. 
Rodríguez y colaboradores (2009) desarrollaron un estudio psicométrico en Madrid, con relación al TDAH en una muestra de escolares de entre 6 y 16 años. El objetivo fue determinar la prevalencia y comorbilidad del trastorno de déficit de atención con o sin hiperactividad. En una primera fase psicométrica se evalúo con "AttentionDeficit/Hiperactivity Disorder Rating Scales IV" para padres y profesores, y una segunda fase de confirmación clínica se utilizaron los criterios DSM-IV. La comorbilidad se estudió mediante el Child Symptom Inventory y confirmación clínica DSM-IV. Se obtuvo como resultado que existe una tasa global de prevalencia del 6,66\% de los cuales el $1 \%$ fue del subtipo hiperactivo, el 1,27\% del subtipo desatento y el 4,38\% del subtipo combinado. En cuanto a la existencia de algún tipo de la comorbilidad entre el TDAH y otros trastornos, este representa el $71 \%$ de los caso, con un $46 \%$ en trastornos de ansiedad, $31 \%$ trastornos de comportamiento, $12 \%$ enuresis, $10 \%$ trastorno por tics y $9 \%$ trastornos del estado de ánimo. Por lo que se concluye que la comorbilidad existente en la presente población afecta significativamente el rendimiento académico y comportamiento escolar.

Vidarte, Ezquerro y Giráldez (2009) realizaron una investigación sobre el perfil psicomotor de los niños con TDAH. Comentan que la calidad del desempeño motor durante los 5-6 primeros años de vida podría constituir un predictor de la posterior aparición de síntomas del trastorno. Además, la asociación entre torpeza motora y TDAH supone un peor pronóstico del cuadro. Siguiendo este modelo se propusieron como objetivo caracterizar el perfil psicomotor de los niños entre 5 y 12 años diagnosticados clínicamente con TDAH en la ciudad de Manizales (Colombia) y compararlo con niños sanos de su misma edad. Se realizó un estudio descriptivo transversal con una muestra de 846 niños (422 diagnosticados de TDAH y 424 sanos). Los resultados obtenidos fueron que si bien todos los factores de la motricidad presentaron valores en rangos de normalidad, dentro de esa categoría los niños con TDAH de todas las edades obtuvieron los puntajes más bajos. Se llegó a la conclusión de que el perfil psicomotor de los niños diagnosticados con TDAH fue "eupráxico" y se clasifica en la misma categoría que los niños sanos, aunque cuantitativamente resultó inferior. Al comparar los factores psicomotores de los niños con TDAH y sanos en las diferentes edades, se aprecia que en ambos grupos mejoran con los años, aunque los niños con TDAH siempre muestran un retraso respecto a los sanos. 
Presentación, Siegenthaler, Jara y Miranda (2010), realizaron un estudio con el objetivo de analizar el mantenimiento de los efectos de una intervención psicosocial sobre la adaptación académica, emocional y social de niños con TDAH, tras un año de su finalización. Este programa se implementó con 27 niños con TDAH de 7 a 10 años, sus padres y sus profesores. La intervención tuvo una duración de 10 semanas e incluyó modificación de conducta, técnicas cognitivo-conductuales, adaptaciones académicas y habilidades sociales. Se valoraron los efectos sobre la adaptación académica, emocional y social a partir de informaciones aportadas por los padres, profesores y compañeros. Los resultados confirman la existencia de mejoras experimentadas tras el tratamiento, especialmente en las áreas académica y social, áreas en las que estos niños presentaban las mayores dificultades.

Quintanar, Gómez, Solovieva y Bonilla (2011) realizaron un análisis de los mecanismos cerebrales que condicionan el cuadro clínico del trastorno por déficit de atención con hiperactividad (TDAH). Se efectuó un análisis cualitativo de errores y rasgos particulares observados durante la ejecución de tareas de evaluación neuropsicológica breve infantil y de la atención, comparando las características de las ejecuciones de niños mexicanos preescolares con TDAH y de niños sin ningún tipo de trastorno. En el estudio participaron 32 niños preescolares de entre 5 y 6 años de edad de escuelas oficiales urbanas de la ciudad de Puebla, México, los cuales fueron divididos en dos grupos: grupo 1, integrado por 16 niños con diagnóstico de TDAH y grupo 2 , integrado por 16 niños sin TDAH. Se utilizaron los instrumentos "Evaluación neuropsicológica infantil breve" y "Evaluación neuropsicológica de la atención". Los resultados revelaron diferencias significativas en el desempeño de los niños sin TDAH, mientras que los niños con TDAH se caracterizaron por un déficit funcional severo en los mecanismos de programación y control, organización secuencial motora, análisis y síntesis espacial y activación cerebral inespecífica. Se llegó a la conclusión de que el TDAH es un síndrome neuropsicológico complejo en el que están implicados, además de las dificultades en el proceso de atención y otras funciones cognitivas aisladas, diversos procesos psicológicos y mecanismos cerebrales.

Puentes, P., y colaboradores. (2014) a través de un estudio buscaron analizar las habilidades sociales (HS) de 159 niños de ambos sexos, escolarizados, con Trastorno por Déficit de Atención-Hiperactividad (TDAH), entre los 6 y los 11 años de edad. Esta valoración se realizó a través de la escala Behavioral Assessment System for Children 
para padres y maestros. Los resultados mostraron que los niños con TDAH presentan puntajes más bajos en las dimensiones de habilidades sociales como escuchar, esperar turnos, leer señales sociales y tener capacidad de adaptabilidad. Sin embargo, en compañerismo, los participantes con TDAH combinado poseen habilidades semejantes a los no afectados. Esto replantea lo encontrado en la mayoría de los estudios en donde únicamente se evidencian deficiencias.

\subsection{Base teórica conceptual}

\subsubsection{Definición}
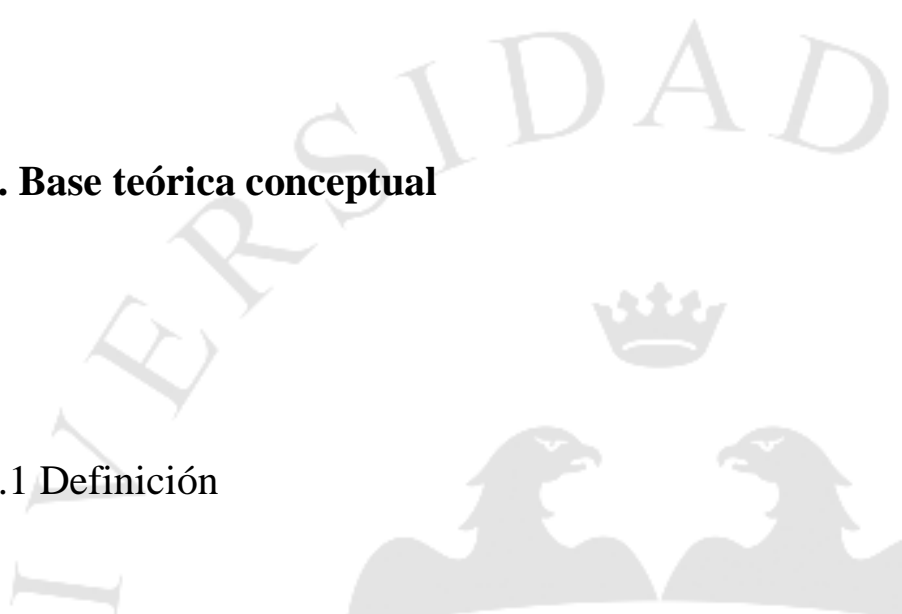

A lo largo de la historia muchos investigadores han estudiado el TDAH, a partir de esto han brindado una gran variedad de definiciones. A continuación se presentará algunas de ellas.

"Es un trastorno del desarrollo de la habilidad para regular el propio comportamiento (el autocontrol). Engloba problemas para mantener la atención y para controlar los impulsos y el nivel de actividad. Estos problemas se reflejan en el deterioro de la voluntad, de la capacidad de controlar su conducta a lo largo del tiempo y para mantener en su mente las metas y sus consecuencias futuras. No es solamente un desatento o hiperactivo, no es un estado temporal que se curará con el tiempo, pero si es normal en la primera fase de la infancia, tampoco se debe a un fracaso de los padres, ni es un signo de malicia. El TDAH es un auténtico trastorno, un verdadero problema y a menudo un obstáculo que puede llegar hacer angustiante” (Barkley, 1999).

Estas problemáticas guardan gran relación con la dificultad para seguir las “conductas gobernadas por reglas" y "con problemas para mantener una forma de trabajo consistente a lo largo de periodos de tiempo más o menos largos” (Barkley, 1990). 
Según el APA (2000) el TDAH “es un patrón persistente de falta de atención y/o hiperactividad e impulsividad, cuya frecuencia y severidad es mayor que lo típicamente observado en personas de un nivel comparable de desarrollo".

Asimismo, “el TDAH y/o TDA es un trastorno que afecta la atención y la impulsividad. En su génesis y desarrollo participan causas neuroquímicas y psicodinámicas y requiere de un tratamiento multidisciplinario" (Gratch, 2000).

Mendoza (2007, citado por Barbudo, 2012), denomina al TDAH como "una escasa o nula capacidad para permanecer atento a estímulos específicos, lo que conlleva a tener deficiencias en el aprendizaje, posible presencia de dislexia, dificultades para leer, digrafía, problemas para escribir, discalculia, manejo impreciso de los números; coordinación motora deficiente, alteración del comportamiento; tanto en la acción como en el lenguaje, problemas de atención, afección de la organización cognitiva; lo que evidencia discrepancia entre sus capacidades potenciales y la ejecución.”

\subsubsection{Síntomas}

Existen una gran variedad de síntomas asociados a este trastorno, entre ellos, el de Herranz y Argumoza (2000) quienes crearon una clasificación para identificar estas dificultades asociadas, resultando involucradas diversas áreas como la motricidad, la conducta, el área emocional, área somática, el lenguaje y las relaciones sociales. A continuación se presenta un cuadro que describe las dificultades que podrían aparecer en cada una de estas áreas. 
Figura 2. 1:

Sintomas asociados

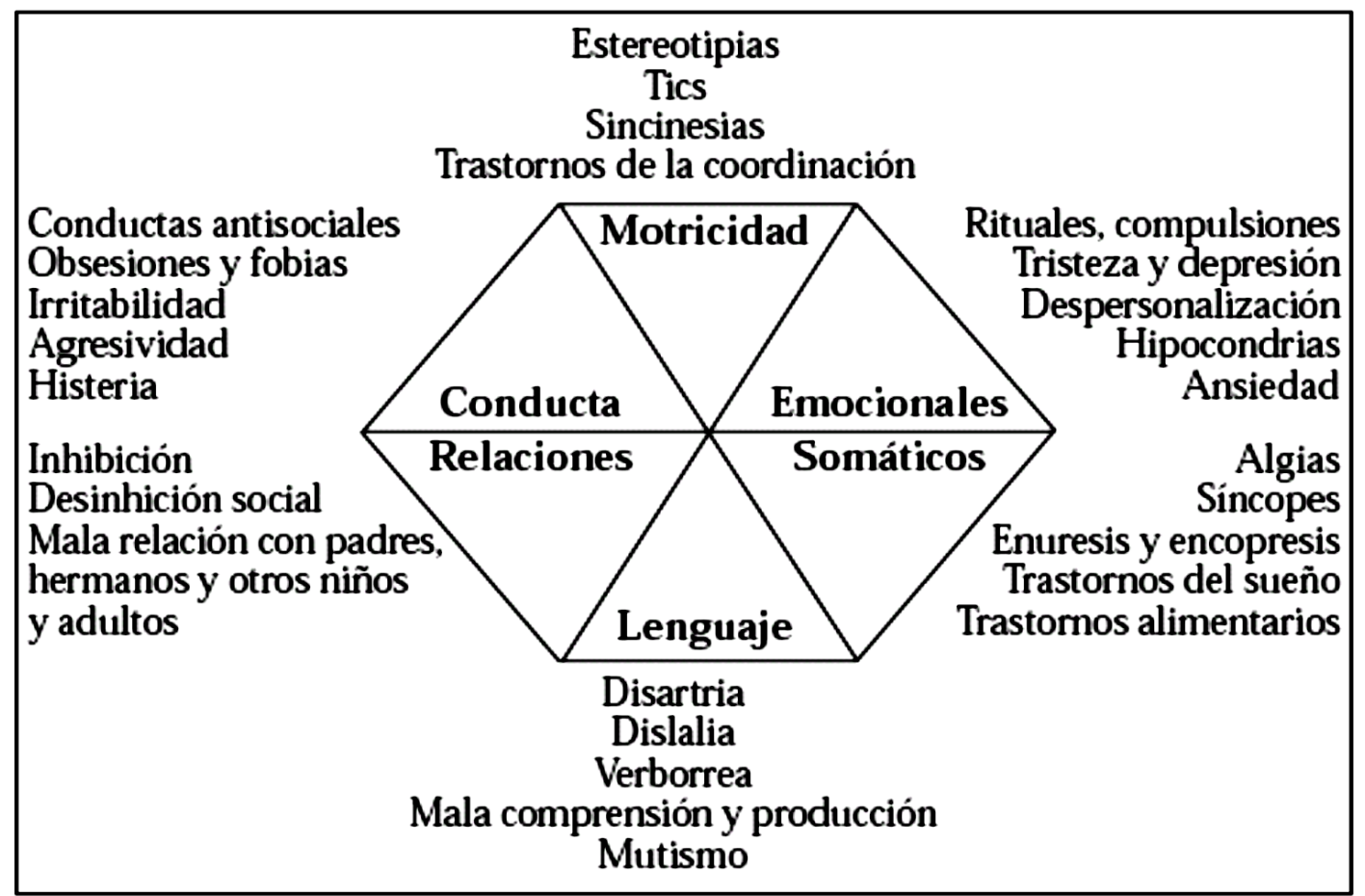

Fuente: Herranz y Argumoza (2000)

La sintomatología de este trastorno tiene consecuencias en el desarrollo del niño y provoca alteraciones sociales, afectivas y de aprendizaje en la escuela, que se van manifestando en las distintas etapas de desarrollo. En la época pre-escolar existen alteraciones del comportamiento. En la edad escolar se mantienen las alteraciones del comportamiento, problemas académicos, problemas de interacción social, que acaban generando problemas de autoestima. En la adolescencia estos problemas se mantienen y aparecen otros nuevos asociados a los anteriores relacionados con los nuevos retos que esta edad plantea, así van apareciendo problemas con las drogas, problemas legales y, en ocasiones, lesiones y accidentes. Finalmente, durante la edad adulta, a los anteriores problemas se asocian los problemas de tipo laboral. Los niños con TDAH que no reciben un tratamiento correcto suelen alcanzar en la edad adulta trabajos o profesiones por debajo de su capacidad. (Ramos-Quiroga et al., 2005)

Algunos problemas que frecuentemente aparecen en el TDAH, como consecuencia directa de las dificultades fundamentales del trastorno son la falta de perseverancia, dificultad en el manejo del tiempo, desorganización, inmadurez emocional, desobediencia, problemas familiares, fracaso escolar, problemas sociales y baja autoestima. (Parellada, 2009) 
Otro problema implicado es que los niños con déficit de atención obtienen un bajo rendimiento en velocidad de procesamiento de la información (Weiler, Bernstein, Bellinger, \& Waber, 2000). Esto contribuyen de manera significativa a la predicción del rendimiento académico (Mayes \& Calhoun, 2007). Las deficiencias en velocidad de procesamiento son un factor de riesgo cognitivo para trastornos de la lectura y TDAH (Shanahan et al., 2006).

Los niños con TDAH que toman metilfenidato de forma selectiva, pueden mejorar la velocidad para nombrar colores, pero no la velocidad para nombrar letras o números. Estos hallazgos implican que el déficit en la velocidad de denominación está asociado con el procesamiento semántico en el TDAH, y se puede mejorar pero no normalizar con metilfenidato (Tannock, Martinussen, \& Frijters, 2000).

\subsubsection{Causas}

En lo referente a las causas del trastorno, se encontró una clasificación que realizó Wiznitzer (2004) en la que destacó que el origen del TDAH tiene como causas primarias las idiopáticas o genéticas en 70 a $80 \%$. Además, existen causas secundarias que pueden ser desnutrición severa en niñez temprana, encefalopatía hipoxia isquémica, traumatismo craneal cerrado, infecciones del SNC (encefalitis, meningitis). También puede deberse a errores del metabolismo (hipertiroidismo), toxinas externas (plomo, alcohol, tabaco), infarto cerebral, desórdenes cromo somáticos, efecto de medicamentos, entre otras causas. Todo esto con una probabilidad de un 20 a 30\%. Asimismo, existen otras causas secundarias que suceden en la etapa perinatal como complicaciones perinatales, niños con LOC al nacer, consumo de alcohol y drogas durante el embarazo, nacimiento muy prematuro y bajo peso al nacer, la exposición intrauterina al alcohol o nicotina, o alergias alimenticias.

El TDAH es un trastorno que se hereda, se han identificado por lo menos dos marcadores genéticos asociados al trastorno: el DRD4 y DAT. Generalmente un padre o pariente cercano tiene también TDAH. Además si un padre tiene el trastorno y además un trastorno de aprendizaje específico, es probable que el niño herede los dos. (Green, 2001) 
Por otro lado, también existen evidencias de que es un problema de ajuste fino del cerebro. Green (2001) comenta que la variante del impulsividad del TDAH presenta una disfunción a nivel del lóbulo frontal, es decir, le cuesta trabajo "frenar" su comportamiento. Además, a través de imágenes obtenidas mediante PET y SPECT, se observó que estos niños recepcionan una cantidad excesiva e innecesaria de información visual y auditiva. Asimismo, señala que los niños con TDAH están demasiado activados cuando deberían estar tranquilos y demasiado pasivos cuando deberían estar concentrados.

Otro factor que puede estar influyendo es el desequilibrio en los neurotransmisores cerebrales, es decir en los niveles de noradrenalina y dopamina. Los fármacos estimulantes, parecen normalizar este desequilibrio. (Green, 2001)

Por otro lado, existen factores familiares y psicosociales que pueden desequilibrar al niño y originar un cuadro similar al TDAH, entre estos se encuentran la muerte de un familiar o amigo muy querido, una madre con trastorno mental, una familia numerosa, un padre alcohólico, drogadicto o delincuente, las peleas de los padres, la clase social baja con ambiente poco afectuoso, el vivir en un barrio conflictivo, el vivir fuera del hogar y sin afecto, el cambio brusco de mejor a peor nivel económico y social. (Castroviejo, 2008)

Desde un punto de vista anatómico existen diferencias estructurales en distintas zonas del cerebro al comparar a niños con TDAH y sin él. Concretamente se encontró que los niños con TDAH poseen los lóbulos frontales más pequeños, sobre todo el derecho (Castellanos et al. 1996, citado por Lavinge y Romero, 2012). Asimismo, citando al mismo autor, "muestran un menor volumen cerebral en distintas zonas de los ganglio basales. Además, la asimetría del núcleo caudado derecho es mayor que la del izquierdo. No obstante, algunas investigaciones consideran que la asimetría es normal." Sumado a esto, el volumen de los lóbulos posteroinferiores del vermis también parece más pequeño (Castellanos et al. 2002, 2004, citado por Lavinge y Romero, 2012). 


\subsubsection{Diagnóstico}

A partir de un consenso en el ámbito académico mundial con respecto al DSM-5, se han establecido ciertos criterios para facilitar el diagnóstico del TDAH en niños y adolescentes. De acuerdo a esto, deben presentarse 6 o más síntomas de inatención o de hiperactividad- impulsividad que hayan tenido una duración mínima de seis meses. Asimismo, estos síntomas deben presentarse en por lo menos dos ambientes y debe alguno de ellos haber existido antes de los doce años de edad. No obstante, existen ocasiones en las cuales estos síntomas no son detectados antes de esta edad. Para que estos síntomas sean considerados parte de un trastorno deben de afectar su vida social, académica o laboral, o reducir la calidad de los mismos. A continuación se presentan los síntomas según el DSM-V

Tabla 2.1

Diagnóstico del TDAH basado en el DSM-5

\begin{tabular}{llllll}
\hline TDA & TDAH & \multicolumn{3}{l}{ TDAH-C } \\
\hline Los síntomas de inatención & Los síntomas de & Los síntomas del \\
son: & hiperactividad son: & & trastorno por déficit de
\end{tabular}

(a) Con frecuencia no presta atención suficiente a los detalles o incurre en errores por descuido en las tareas escolares, en el trabajo o en otras actividades

(b) A menudo tiene dificultades para mantener la atención en tareas o en actividades lúdicas (a) Con frecuencia atención e hiperactividad mueve en exceso manos combinado se refieren a o pies, o se remueve en los síntomas de su asiento inatención sumandos a (b) Con frecuencia los de hiperactividad. abandona su asiento en la clase $o$ en otras situaciones en que se espera que permanezca sentado 


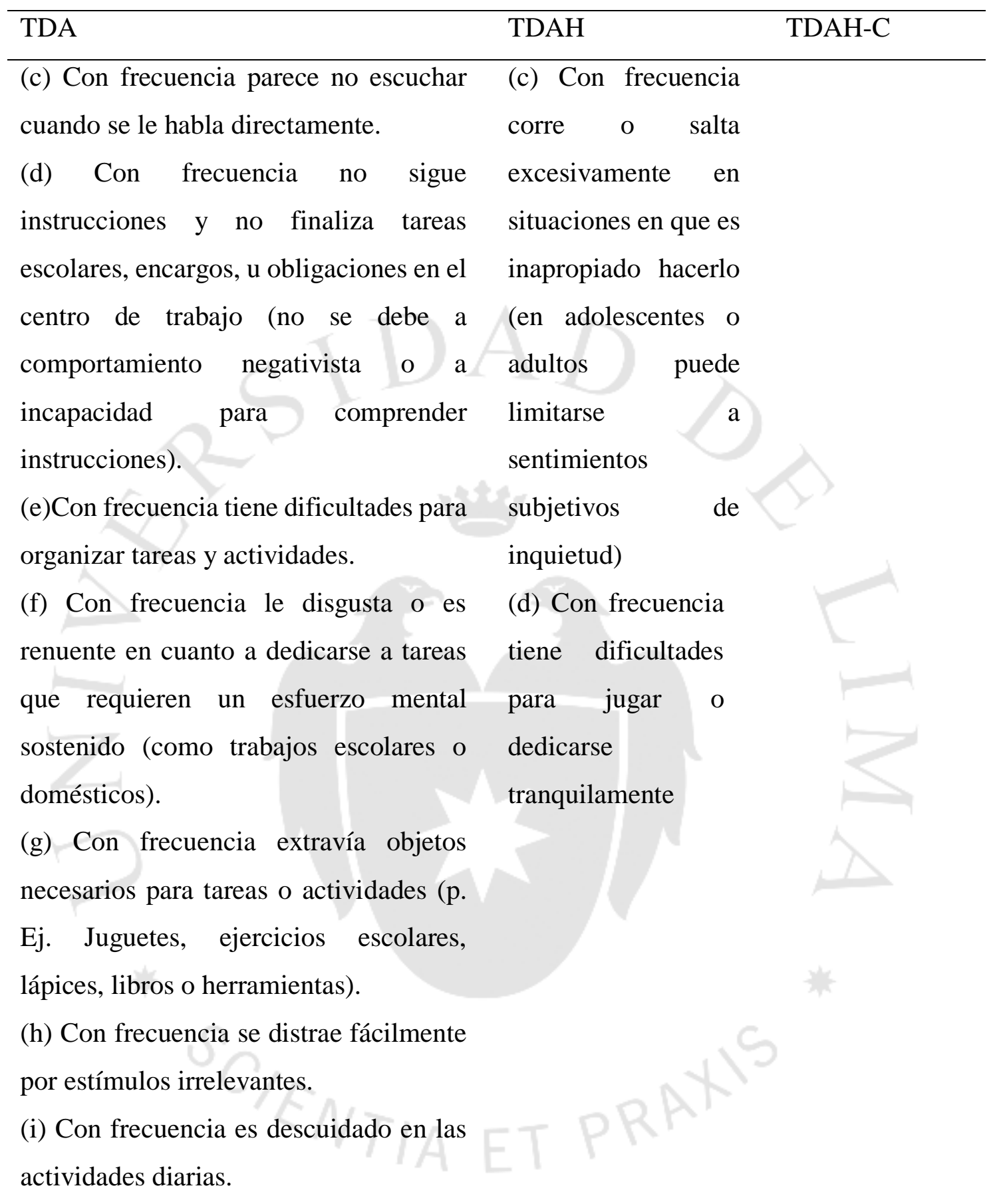

Fuente: American PsychiatricAssociation. (2014). Guía de consulta de los criterios diagnósticos del DSM-5. American psychiatricpublishing. Washington, DC. 438 p

Existen tres variantes clínicas del TDAH: el tipo combinado, que presenta déficit de atención e hiperactividad-impulsividad y es la más frecuente (TDAH-C); el tipo en el 
que predomina la hiperactividad-impulsividad (TDAH) y el tipo en el que predominio es de déficit de atención (TDA).

El tipo disatencional se caracteriza por la presencia de síntomas de ansiedad, mayor nivel de aprehensión, miedos inmotivados, son niños confusos, lentos y perezosos. Asimismo, cometen errores ante instrucciones orales y escritas. Poseen problemas de memoria, deficiencia en las pruebas de velocidad perceptiva motora u óculo manual, presentan mayor dificultad para recordar lo aprendido y dificultades en la codificación de la información de entrada. A pesar de esto, son poco agresivos y son capaces de tener buenas relaciones sociales. (Filomeno, 2009)

El tipo impulsivo, es inquieto, corre en forma excesiva, verborreico, se encuentra en constante actividad y presenta mayor agresividad y dificultad en su relación con los pares. En la adolescencia presenta conductas antisociales. En el tipo combinado se encuentran implicadas las características de ambos tipos. (Filomeno 2009)

Además se debe especificar si es de remisión parcial y la gravedad actual de los síntomas; leve, moderado o grave. (American Psychiatric Association, 2014)

\subsubsection{Comorbilidad}

Estos trastornos de origen biológico están influidos notablemente por el ambiente familiar y escolar del niño. Un entorno de aceptación familiar, apoyo, afecto y contención se asocian a un mejor pronóstico para estos niños. (Green, 2001)

En la mayoría de los casos, el TDAH presenta comorbilidad con algún otro trastorno, pudiendo ser más de uno. Los trastornos de aprendizaje al igual que los problemas de conducta son los que se asocian con mayor frecuencia al TDAH, y son una de las principales razones por las cuales los niños y adolescentes son derivados al psicólogo. Al indagar en la historia clínica generalmente aparecen antecedentes de problemas del habla o del lenguaje, siendo el más frecuente la dislalia y el menos frecuente el retraso del habla. Debido a esto, se recomienda a los niños asistir a una terapia del lenguaje para prevenir o aminorar futuros problemas de aprendizaje (Filomeno, 2009). 
El niño con TDAH puede desarrollar un problema no específico del aprendizaje. Este problema se produce mayormente como consecuencia del déficit de atención, el cual causa que el menor no pueda mantener la atención necesaria para consolidar su aprendizaje (Filomeno, 2009). En menor grado, pueden ocasionarse debido a la hiperactividad, que no permite que permanezca tranquilo y sentado realizando sus tareas en clase o casa. En el primer caso es necesaria una terapia de atención-concentración, para brindarle las pautas que lo ayuden a organizarse y enfocar su atención a estímulos relevantes; y en el segundo sería necesaria una terapia conductual para enseñarle a controlar su cuerpo y sus conductas.

Con respecto a los problemas de conducta asociados al TDAH, el más frecuente es el trastorno negativista desafiante (TND), que presenta una frecuencia similar a la de los problemas de aprendizaje (Filomeno, 2009). Este trastorno se considera el mayor problema que puede tener un niño con TDAH, aumentando el riesgo de drogadicción y abandono escolar. Este trastorno se caracteriza según el DSM-V, como "un patrón recurrente de conducta negativista, desafiante, desobediente y hostil hacia figuras de autoridad que se mantiene por lo menos durante seis meses."

Los comportamientos negativistas y desafiantes se expresan a través de un cuestionamiento persistente, resistencia y desobediencia de las órdenes, evitación de responsabilidades, negativa a ceder o negociar con adultos o compañeros. Igualmente existe una tendencia deliberada a sobrepasar los límites o normas establecidas, aceptando mal o culpabilizando a otros de sus propios actos (Banús, 2006).

Pueden manifestar hostilidad tanto a figuras de autoridad como compañeros. Esta agresividad se puede producir de forma deliberada, sin causa aparente o por motivos insignificantes. Durante los mencionados episodios suelen aparecer insultos o palabras despectivas hacia las otras personas pero sin llegar aún a la agresión física. En el caso de que se produzcan conductas abiertas de agresión a otro, estaríamos, probablemente ante un trastorno disocial. Se debe de manejar el problema conductual a través de terapias conductuales o cognitivo conductuales para tratar de evitar que un TND derive en un trastorno disocial. (Rigau, García, Artigas, 2006)

Por otro lado, Filomeno (2009) explica que la depresión tiene una determinada relación genética con el TDAH, pues es más frecuente en los pacientes con este trastorno y sus familiares, lo que puede deberse a los múltiples problemas y frustraciones que son 
comunes en el TDAH, sobre todo en niños y adolescentes. Cuando coexisten el TDAH y la depresión, debe tratarse en primer lugar el trastorno que se presenta en mayor intensidad. Entonces, cuando se produzca una mejoría considerable en el trastorno principal, se inicia el tratamiento para el problema secundario. Se debe trabajar siempre el autoconcepto para lograr una mejora en el pronóstico.

Indica además, que de los trastornos asociados con el TDAH, uno de los más estudiados es el bipolar (TB) ya que es común que exista una comorbilidad entre ellos. El diagnóstico debe considerarse si existe historia de bipolaridad en la familia, mayor hiperactividad de la usual, irritabilidad, conductas desafiantes que no se adecuan al tratamiento conductual y existen alteraciones de sueño.

Por otro lado, estudios realizados señalan que entre un 25 y $85 \%$ de los sujetos con trastorno de la Tourette presenta un TDAH comórbido, y cuanto más grave sea el trastorno de la Tourette, más probable será que presente el TDAH (Comings y Comings, 2003, citado por Lavinge y Romero, 2012).

\subsubsection{Diagnóstico diferencial: Asperger- TDAH}

Según la Universidad Internacional de Valencia (2015), el trastorno por déficit de atención e hiperactividad y el trastorno de espectro autista, o síndrome de asperger, son dos condiciones distintas e independientes. Sin embargo, ambas condiciones tienden a presentarse asociadas con una frecuencia significativamente alta (Gillberg y Ehlers, 1998). Es por esto que es usual encontrar una alta proporción de niños con Asperger que también presentan TDAH. Además, existen coincidencias en algunos de sus síntomas que en ocasiones pueden generan confusiones entre padres y educadores e incluso errores en el diagnóstico.

Debido a la importante asociación entre ambos trastornos, es crucial elaborar un diagnóstico diferencial ayudados de un especialista, ya que el tratamiento y la intervención educativa son distintos en ambos casos. (Fundación CADAH, s.f)

En opinión de la mayoría de especialistas, las dificultades para diferenciar un niño con TDAH de otro con Asperger se dan durante los primeros años de vida, que es cuando 
en ambos casos diagnósticos los niños sufren trastornos muy parecidos: dificultad para interpretar y entender los sentimientos de los demás, problemas de atención, conductas hiperactivas y, en ocasiones, también compulsivas y dificultades de autocontrol y autorregulación de la conducta. (Universidad Internacional de Valencia, 2015)

Durante la etapa preescolar gran cantidad de niños con cualquiera de las dos patologías (TDAH o Asperger) pueden tener un desarrollo muy similar, lo que dificulta en gran medida el diagnóstico. Generalmente, se trata de niños a los que se les dificulta mucho relacionarse con los demás, no comparten juegos ni objetos y, en lo que respecta a actividades, les cuesta mucho recortar y colorear. Las rabietas también suelen ser comunes en ambos casos y están poco dispuestos a pedir ayuda a los demás.

A medida que van creciendo, los niños con TDAH se van diferenciando de los que tienen Asperger. Mientras que los problemas de atención siguen afectando el rendimiento académico de los niños con déficit de atención e hiperactividad, los chicos con Asperger logran concentrarse de manera adecuada, lo cual les permite un buen aprendizaje, llegando a sobresalir en las áreas que son de su interés. (Universidad Internacional de Valencia, 2015)

Las diferencias más significativas entre ambos diagnósticos clínicos pueden resumirse así:

Tabla 2.2

Diagnóstico diferencial

\begin{tabular}{lll}
\hline Asperger & TDAH \\
\hline $\begin{array}{l}\text { Presenta un comportamiento errático } \\
\text { usual sin causa aparente }\end{array}$ & $\begin{array}{l}\text { Su comportamiento errático se produce } \\
\text { como respuesta a un factor o evento } \\
\text { desencadenante }\end{array}$ \\
Tiene afectadas sus habilidades de & Logra interactuar con otros, pero le \\
comunicación y lenguaje. Le cuesta & $\begin{array}{l}\text { cuesta para esperar su turno, } \\
\text { entender las señales sociales o } \\
\text { expresiones faciales. }\end{array}$
\end{tabular}




\section{Continuación tabla 2.2}

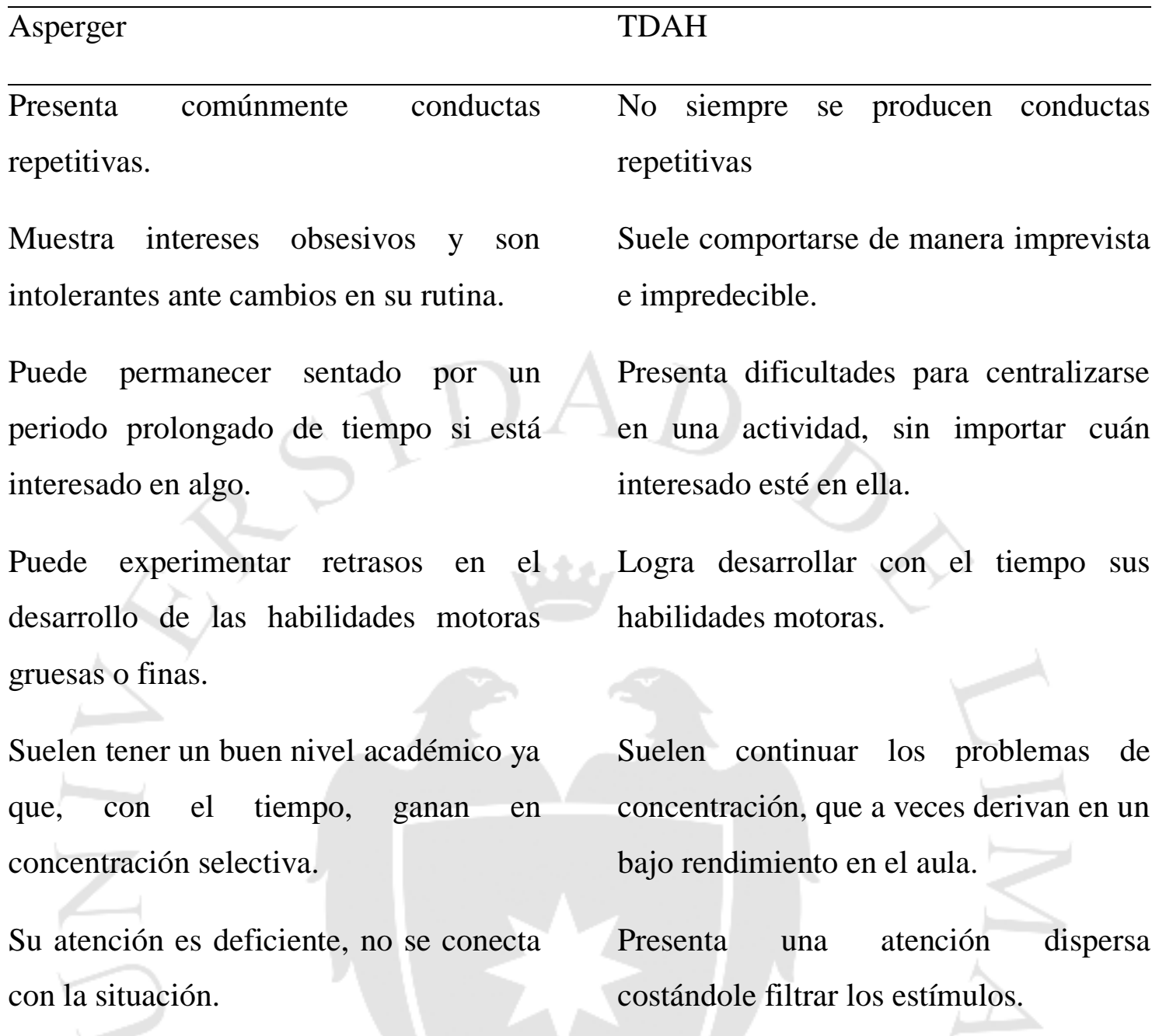

Fuente: Universidad Internacional de Valencia. 2015. Similitudes y diferencias entre los síntomas de TDAH y síndrome de Asperger.

En lo que respecta a intervención educativa, en los niños con Asperger debe enfocarse a mejorar la interacción social, mientras en los niños con TDAH el principal objetivo debe ser el aumento de la concentración. (Universidad Internacional de Valencia, 2015)

\subsubsection{Modelos explicativos}

Existen diversos modelos explicativos que intentan entender mejor el TDAH y sus repercusiones en la vida. Douglas (1980), propone que existe un rechazo o desinterés 
por brindar atención y esfuerzo a tareas complejas, propensión a la búsqueda de gratificación inmediata, poca capacidad para inhibir respuestas impulsivas y para regular la activación en la resolución de problemas. Este patrón de comportamiento y de procesamiento de información provoca a largo plazo deficiencias secundarias en general de orden cognitivo que se dividen en tres grandes grupos: 1. Déficit en el desarrollo de esquemas y estrategias que los conlleva al déficit de resolución de problemas. 2. Déficit en motivación intrínseca asociada a pobre rendimiento que los conlleva a la expectativa de fracaso e incapacidad. 3. Déficit metacognitivo que los llevará a la incapacidad para planificar y controlar las acciones propias. Al final, y al llegar a la pre-adolescencia se tiene un aprendizaje de fracaso. Estos fracasos ayudan a perpetuar el patrón de las predisposiciones básicas cerrando un espiral de mutua influencia donde prevalece un déficit de hipoactivación cortical (búsqueda de sensaciones, precipitación, incapacidad para mantener la atención, etc.). Este modelo ha tenido polémicas llegando a considerarlo más ajustable al TDA.

Otros investigadores como Zentall (1983) proponen que los niños con TDAH tiene umbrales de activación más elevados por lo tanto cuando decrece el nivel de estimulación ambiental las conductas inatentas e hiperactivas serian un sistema de compensación para mantener en su nivel óptimo de activación al SNC.

Haenlein y Caul (1987) plantean que los umbrales de reforzamiento en las aéreas corticales implicadas en este tipo de aprendizaje pueden ser demasiado altos, de modo que el mismo tipo o la misma cantidad de reforzadores positivos tiene efectos más débiles para los niños hiperactivos que para los niños normales.

"La atención integra las funciones ejecutivas del cerebro: activación, concentración, esfuerzo, memoria y autocontrol emocional y de la capacidad de inhibición". (Brown, 2001)

Otro modelo explicativo que surgió a finales de los años 80 es el de Barkley, llamado modelo de desinhibición conductual, en el que reconsidera una reevaluación de los dos principales síntomas: la inatención y la impulsividad. Considera que es un problema de control de impulsos, donde la inatención es entendida como la inadecuada relación que se produce entre un estímulo y la conducta que debería desencadenar. La impulsividad, asimismo, refleja una incapacidad para demorar satisfacciones y precipitación en la consideración de las condiciones estimulantes presentes. Esto lo lleva 
a identificar dos tipos de déficits: una incapacidad para generar conductas gobernadas por reglas y una respuesta anormal a las consecuencias del medio. La primera, expresan el control de conducta por parte del lenguaje lo que ocurriría primero por parte del adulto y por un proceso de maduración e interiorización el propio niño lo asumiría, sin embargo en estos caos no sucede así. En lo que respecta al segundo tipo de déficit, es un déficit en el efecto de los estímulos reforzadores, un efecto inusualmente más rápido de habituación o de saciedad a estos estímulos. Afecta la forma habitual con la que los programas de refuerzo mantienen la conducta de los individuos. (Servera y Barceló, 2005).

Brown (2006, citado por Parellada 2009) considera que la autorregulación de la propia conducta, explica el problema básico de las personas con TDAH. Barkley considera el TDAH como un trastorno de la inhibición y la autorregulación (Barkley y Murphy, 2006, citado por Parellada, 2009).

Gray (1994) y Quay (1997) explicaron que el TDAH puede deberse a dos factores: el primero es debido a una reducción en el funcionamiento del sistema de inhibición conductual, de modo que el castigo o su amenaza no consigue inhibir o regular las conductas como en los demás niños. El otro factor es debido al sistema de activación conductual, que se encarga de regular los aprendizajes tanto por reforzamiento positivo, como negativo. (Lavinge y Romero, 2010)

"El núcleo central del modelo cognitivo y de déficit único de Barkley (2006a) es la afirmación de que los principales problemas de las personas con TDAH tienen su raíz en el déficit para inhibir su conducta." (Lavinge y Romero, 2012).

Barkley (2006 , citado por Lavinge y Romero, 2012) propone un "Modelo híbrido de autorregulación y funciones ejecutivas", mediante el cual intenta explicar que la base del TDAH es el déficit en la inhibición comportamental lo cual produce un impacto adverso sobre la autorregulación y sobre cuatro funciones ejecutivas: memoria de trabajo no verbal, memoria de trabajo verbal, autorregulación del afecto, la motivación, así como en la activación y la reconstrucción. 


\subsubsection{Pronóstico}

El pronóstico de un niño con TDAH va a depender de la severidad y complejidad de su trastorno, es decir, si este se presenta solo o asociado a otros trastornos. Para este investigador existe un mejor pronóstico para aquellos pacientes que cuentan con sólo los síntomas centrales del TDAH (déficit de atención, hiperactividad-impulsividad o ambos combinados), disponen de un alto coeficiente intelectual, viven en un hogar estable con padres dedicados a sus hijos, asisten a un colegio privado que cuenta con profesores preparados y actualizados, relativamente con pocos alumnos y una currícula de clase flexible. (Gómez, 2006)

Para Filomeno (2009), un niño con TDAH que cuenta con todas las herramientas y facilidades para desarrollar sus potenciales, puede convertirse en un adulto creativo e innovador. Expresa que "la impulsividad o falta de disposición para seguir el procedimiento usual en el aprendizaje o para enfrentarse a los problemas que se presentan a diario, lleva a la persona con TDAH a buscar caminos o soluciones breves y fáciles, que es la ruta que lleva a las innovaciones, a las invenciones o a cualquier tipo de creatividad."

Lamentablemente estas circunstancias ideales no ocurren por completo, ya que existe una imposibilidad de coordinar y controlar todas las áreas del desarrollo del niño. Si este llega a la etapa de la adolescencia y todavía no ha encontrado la orientación ni el autocontrol suficiente, presentará problemas de conducta, no se controlará y tendrá una mala formación académica, existiendo una gran probabilidad de que caiga en la drogadicción, la vagancia y la desocupación. Es por esto, que se debe brindar un tratamiento psicológico adecuando a los niños con TDAH para ayudarlos a aprender a regularse, organizarse y fortalecer su autoestima, para lograr ser adultos responsables y maduros. Filomeno (2009)

El TDAH, si no se diagnostica y trata de forma correcta puede limitar el potencial individual durante la etapa adulta. Si hablamos de adaptación emocional, educativa y social, aproximadamente un $20 \%$ de los niños con TDAH persistente funcionan mal en las tres áreas en estudios de seguimiento, otro $20 \%$ está bien adaptado, y otro $60 \%$ está en situación intermedia. (Parellada, 2009) 
Existen muchos adultos que han logrado aprovechar las características de cada uno y buscar una ocupaciones que les vaya bien con las virtudes y limitaciones de cada cual. Sin embargo, no hay que olvidar que en general el TDAH supone más limitaciones que ventajas. Con la edad la hiperactividad y la impulsividad suelen atenuarse, pero el tipo de dificultades que se presentan en la etapa adulta son las mismas que en la infancia, trasladadas al contexto de los mayores. (Parellada, 2009)

\subsubsection{Prevención}

Orjales, I (2012), sugieren que se deben tomar medidas de prevención para la prevención del fracaso escolar en niños con riesgo de TDAH. Esto involucra trabajar para una comprensión real y a fondo por parte de padres y profesores, realizar una detección de los niños con riesgo de TDAH lo más tempranamente posible, valorar en paralelo, la existencia trastornos específicos del aprendizaje, actuar sobre los síntomas en el momento en que estos sean significativos sin esperar al diagnóstico definitivo: en el aula e implementando un programa psicoeducativo individual que incluya entrenamiento específico en estrategia de aprendizaje.

\subsubsection{Evaluación}

Existe gran variedad de herramientas para evaluar la presencia del TDAH. Las principales vías son las entrevistas, las escalas informadas por padres, maestros y el propio niño y las observaciones directas. No obstante, los resultados de las pruebas nos dan, junto con los mencionados anteriormente, una valoración global de que potencialidades y qué debilidades presenta el niño.

Las principales áreas de evaluación son las siguientes: 
Tabla 2. 3

Áreas y herramientas de evaluación

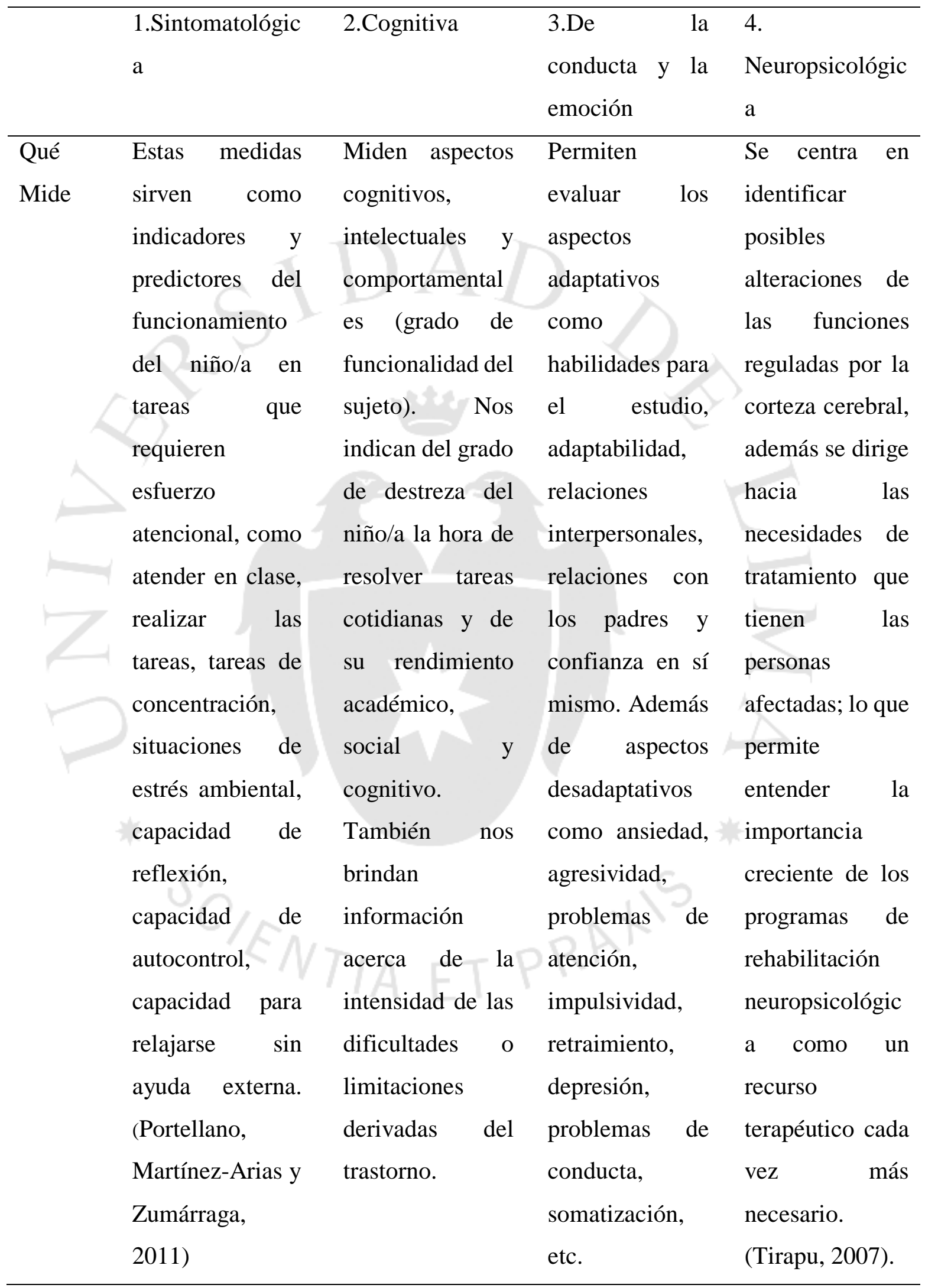

Continuación Tabla 2.3 


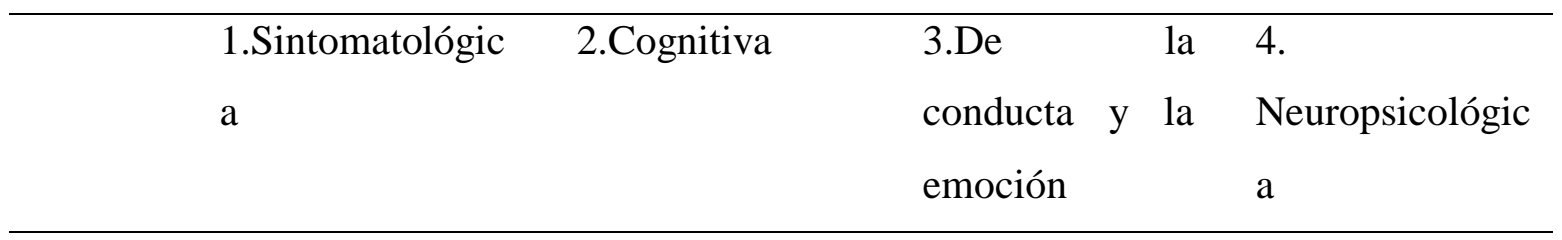

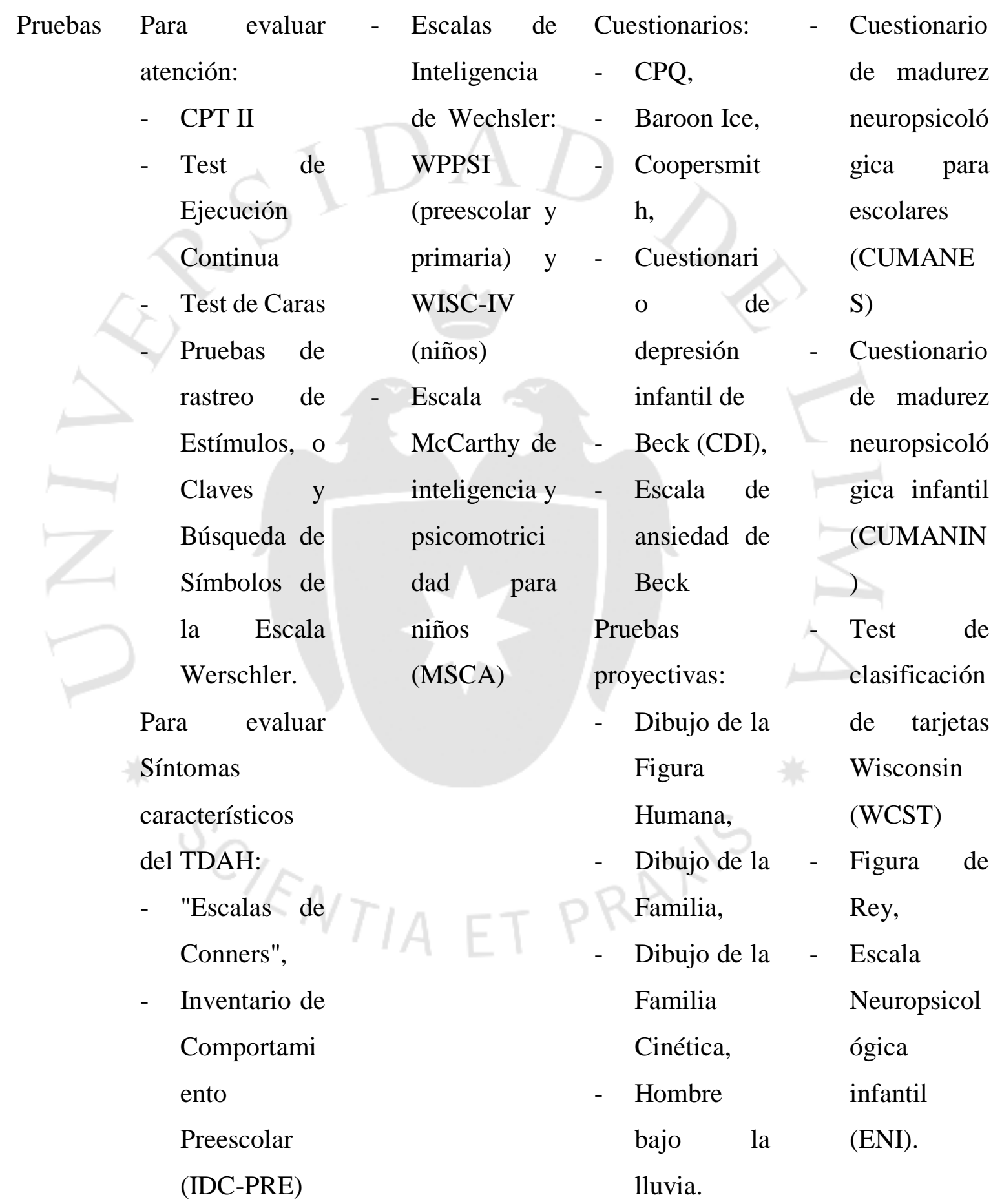

Un diagnóstico correcto y a tiempo es el primer paso para un buen tratamiento del Trastorno por Déficit de Atención e Hiperactividad (TDAH) y para la prevención de 
sus complicaciones así como para poder descartar otras patologías. Generalmente los padres, profesores, orientadores, pedagogos, o pediatras son los primeros en sospechar un posible caso de TDA-H (Soutullo y Díez, 2007.)

\subsubsection{Tratamiento}

Los objetivos a trabajar durante la terapia se orientan a reducir conductas sintomáticas del TDAH, mejorar el ajuste social y la autoestima, favorecer la relación social, tratar los problemas coexistentes, promover el aprendizaje escolar, reducir el distrés familiar.

Esta evaluación debe dar paso a una lista de conductas objetivo para el tratamiento. Las conductas objetivo son aquellos comportamientos que necesitan ser modificados para que el niño mejore. Puede tratarse de conductas que deban eliminarse, o de habilidades nuevas que deban aprenderse. (Children and Adults with AttentionDeficit/Hyperactivity Disorder (CHADD), 2004)

Es posible que las áreas a las que apunte el tratamiento no sean los síntomas del TDA/H (tales como hiperactividad, falta de atención, y actuar de manera impulsiva y repentina sin pensar). En cambio, podrían abordar los problemas que esos síntomas causan en la vida diaria, tales como jugar sin entrar en conflicto con los hermanos y hermanas, u obedecer los pedidos de los padres. (CHADD, 2004)

Se pueden llevar a cabo tratamientos conductuales similares tanto en el hogar como en la escuela. Los padres y los profesores vigilan de manera cuidadosa la respuesta del niño al tratamiento. El tratamiento se modifica a medida que el niño cambia. Los síntomas del TDAH se superponen cada vez más con los síntomas del deterioro de las funciones ejecutivas (Castellanos, 1999). Es por esto que además de técnicas conductuales también se trabaja con técnicas cognitivas. Se trabaja progresivamente en el reconocimiento de emociones básicas, identificación de pensamientos, identificación de la relación entre pensamiento y emoción, identificación del comportamiento, identificación de la relación pensamiento-emoción-comportamiento y de las causas y consecuencias del comportamiento, identificación de las soluciones, auto percepción/ autoimagen y cómo decir lo que siento y pienso. (CHADD, 2004) 
La terapia conductual adecuada implica un trabajo intensivo y prolongado con los padres con el objetivo de entrenarlos para que tenga un manejo más adecuado del niño con TDAH y ayudarlo a desarrollar una más eficiente auto-regulación de su conducta. Los padres deben aprender a anticiparse a los problemas y desarrollar adecuadas técnicas para manejarlos. También es muy importante involucrar a los profesores del colegio en el tratamiento, enseñándoles a aplicar técnicas de modificación de conducta y realizar acomodaciones en la clase para ayudar al niño a mejorar su desempeño académico o su conducta (Voeller 2004).

Las principales estrategia a trabajar con los padres son técnicas de manejo de la conducta del niño, tales como la aplicación de reforzamiento o castigo como consecuencia de las conductas adecuadas o inadecuadas, respectivamente. Los refuerzos generalmente consisten en elogios, privilegios o fichas. "Los castigos generalmente consisten en la pérdida de la atención positiva, de privilegios, de fichas o del refuerzo" (Delgado y colaboradores, 2012, citando a Smith et al. 2006). "Las consecuencias deben ser proporcionadas en forma consistente, inmediata, frecuente, externalizada y destacada" (Delgado y colaboradores, 2012 citando a. Barkley 2006). Se debe usar formas apropiadas para hacerle saber al niño lo que se espera de él, usar afirmaciones del tipo "si haces esto - entonces", tiempos fuera durante o después de conductas inapropiadas, usar cuadros diarios y sistemas de puntos para las recompensas y consecuencias, utilizar un sistema de intercambio de notas entre la escuela y el hogar para premiar conductas en la escuela y dar seguimiento a las tareas escolares

Todavía no se ha encontrado una cura para este desorden, pero existen muchos tratamientos que pueden ayudar efectivamente a su manejo. Según Palacios y colaboradores (2009), hay dos pilares fundamentales para el manejo de los niños preescolares con TDAH. En primer lugar se encuentran las intervenciones psicosociales como el entrenamiento en manejo parental y la terapia interaccional padre-hijo y, por otra parte, se tiene el tratamiento farmacológico a corto y largo plazo en especial con el metilfenidato.

Lo principal es, en el caso de los niños, la educación a la familia y al personal escolar acerca de la naturaleza del desorden y su manejo. Asimismo, según las investigaciones, el tratamiento médico contribuye a una mejora en estos pacientes. Este, apoyado de un tratamiento psicológico, tal como modificación de conducta en el aula y 
el adiestramiento a padres en métodos de manejo de la conducta del niño, han demostrado producir beneficios a corto plazo. (Barkley, Murphy y Bauermeister, 2012)

En el caso de niños con dificultades de atención entre 5 y 11 años, el especialista de aprendizaje siguiere trabajar en conjunto con los padres y niños estableciendo rutinas y herramientas que les permitan realizar las tareas de una manera menos conflictiva. Por ejemplo, se pueden utilizar listas de tareas para todo, desde salir a tiempo de casa en la mañana, hasta hacer los deberes después de la escuela y prepararse para dormir. Es importante definir claramente los pasos necesarios para completar una tarea antes de hacerla debido a que muchas veces estos pasos no son obvios para los niños con TDAH, esto hará que la tarea sea menos abrumadora y más alcanzable. (Miller, 2014)

"Los terapeutas educacionales también recomiendan asignar un tiempo límite a cada paso, particularmente para grandes proyectos a largo plazo. Usar un planificador es esencial para los niños con TDAH con una memoria de trabajo pobre, es decir, que les resulta difícil recordar cosas como los deberes. Una tabla de recompensas en casa y en la escuela, puede ayudar a motivar a los niños que se distraen fácilmente y tienen dificultad para adquirir habilidades nuevas" (Miller, 2014).

Según Orjales y Polaino-Lorente (2001), la intervención psicológica en los niños y adolescentes con TDAH debe orientarse a las áreas en las que el paciente presenta algún problema, sea cognitivo, emocional o comportamental. Si nos orientamos a un abordaje psicoeducacional este involucraría explicarle al niño sobre su trastorno, las posibles dificultades y peligros que se asocian a este, ayudándolo a aceptar su diagnóstico y que se comprometa con la terapia.

Una terapia cognitivo conductual se enfocaría en desarrollar y orientar de manera personal al niño, brindándole estrategia de resolución de problemas, entrenamiento en auto instrucciones y auto regulación emocional. Además lo ayudaría en su organización y planificación en función de los objetivos y metas de la terapia. Asimismo, práctica en entrenamiento en habilidades sociales, en el cual se refuerzan la autoestima y la comunicación asertiva, las reglas de socialización y las competencias sociales. (Orjales y Polaino-Lorente, 2001)

Algunos síntomas asociados al TDAH son el estrés y la ansiedad, es por esto que en terapia se utilizan técnicas de relajación y control del estrés. Estas técnicas además de 
la relajación utilizan la respiración y la expresión corporal. Además fomentan la realización de actividades externas como actividades deportivas, hobbies, actividades socio-culturales (Orjales y Polaino-Lorente, 2001).

Luria (1988) y Kirby y Grimley (1992), resaltan la importancia del lenguaje interno para comprender y regular los mecanismos que dirigen la atención voluntaria. Es por esto que los niños con déficits de atención pueden beneficiarse a través del uso de este tipo de lenguaje, logrando aumentar su concentración y reducir su impulsividad. El lenguaje interno o las autoinstrucciones ayudan a interiorizar de las reglas e instrucciones, ya que fomentan el pensamiento organizado y reflexivo. Estas técnicas tienen como objetivo que el niño interiorice pautas de actuación generalizables a distintas situaciones con el fin de alcanzar los objetivos propuestos.

Por otro lado, Según Alcalde (2004) refiriéndose a la terapia psicoanalítica, el tratamiento del TDAH debe ser un proceso activo y multidisciplinario, que requiere tanto una reestructuración interna como externa. La reestructuración interna implica percatarse de las apreciaciones negativas que se tiene de sí mismo y tratar de deshacerse de ellas, tratando re-pensar la imagen devaluada de sí mismo. Esto ayuda al paciente con TDAH a dejar atrás sus heridas y fracasos pasados, a aprender a aceptarse con sus defectos, a abandonar esas defensas que creaban barreras entre él y los demás. Este tipo de terapia se orienta a reestructurar defensas, trabajando los traumas para lograr sustituir las defensas patológicas por unas más saludables.

Continuando con la misma autora, el terapeuta psicoanalítico deberá participar monitoreando al paciente y re direccionándolo para que no se pierda en monólogos, dando prioridad a las creaciones mentales, prestando atención a lo relevante y dejando pasar el material inservible. Todo esto con la idea de que "si las personas pueden variar la forma en que piensan y sienten sobre sí mismas o sobre algún aspecto de sus vidas, este cambio se ha producido porque el "hablar sobre sus problemas" ha modificado la forma de funcionar de su cerebro."

Según Alcalde (2004), es importante resaltar que la psicoterapia psicoanalíticamente puede ayudar al paciente con TDAH, pero el tratamiento es en conjunto; se debe combinar la terapia con la medicación en caso de ser necesario, para obtener mejores resultados. En los casos de pacientes adultos en que los síntomas de 
TDAH se han atenuado y lo que queda son los traumas de una infancia con TDAH, la psicoterapia psicoanalítica es la mejor opción. 


\section{CAPÍTULO III. OBJETIVOS}

\subsection{Objetivo General}

- Determinar estrategias de intervención preventivas acorde a las características del caso de un niño con TDAH en etapa pre-escolar.

\subsection{Objetivos Específicos}

- Describir las características específicas del caso de un niño en etapa pre-escolar con Trastorno de Déficit de Atención e Hiperactividad.

- Identificar las consecuencias del TDAH a nivel académico y social en el caso de un niño que se encuentra en etapa pre-escolar.

- Definir los tratamientos psicológicos adecuados en el caso de un niño con TDAH que se encuentra en etapa pre-escolar.

- Reconocer los beneficios de un tratamiento psicológico en el caso de un niño con TDAH que se encuentra en etapa pre-escolar.

- Trabajar las áreas deficitarias y las fortalezas del caso, respondiendo a su perfil individual.

- Trabajar en conjunto para fortalecer el autocontrol, el manejo de emociones y la adaptación a su entono. 


\section{CAPÍTULO IV. MÉTODO}

\subsection{Tipo y diseño de investigación}

Se realizará una investigación de estudio de caso único mediante procesos mixtos, es decir cualitativos y cuantitativos. Hernández y Mendoza (2008) describen el estudio de caso como "una investigación sobre un individuo, grupo, organización, comunidad sociedad, que es visto y analizado como una entidad." Según Yin (2009) los diferentes diseños se superponen en los estudios de caso, utilizando múltiples fuentes empíricas.

Según Martínez Carazo (2006), "el estudio de caso es una estrategia de investigación dirigida a comprender las dinámicas presentes en contextos singulares, la cual podría tratarse del estudio de un único caso o de varios casos, combinando distintos métodos para la recogida de evidencia cualitativa y/o cuantitativa con el fin de describir, verificar o generar teoría."

Harvard Business School (1997) establece las siguientes fases para el estudio de caso:

1. Identificar el caso

2. Investigación de antecedentes y su contexto

3. Solicitar permiso de los involucrados

4. Involucrar al evaluado

5. Trabajo de campo 
6. Análisis de los datos

7. Elaboración del reporte del caso

\subsection{Participante}

Salomón (S) es un niño de 5 años de edad, diagnosticado con trastorno de déficit de atención con hiperactividad de tipo mixto. Presenta una estatura y peso promedio para su edad. Tiene pelo castaño oscuro, ojos marrones y usa anteojos. Su familia está conformada por ambos padres de 40 años y su hermana mayor de 8 años. Los padres se encuentran separados, los hijos viven con la madre y se quedan los fines de semana en casa del padre. El nivel sociocultural de la familia es medio y los padres muestran una relación positiva entre ellos, no obstante la madre es la que se encarga especialmente de la crianza y el cuidado de los hijos. Salomón asiste a un colegio privado de educación personalizada.

\subsection{Técnicas de recolección de información}

Se medirán las variables de estudio a partir de entrevistas con los padres y el niño, observaciones de conducta, reportes del colegio y a través de instrumentos psicológicos. 
Tabla 4. 1

Instrumentos de evaluación utilizados

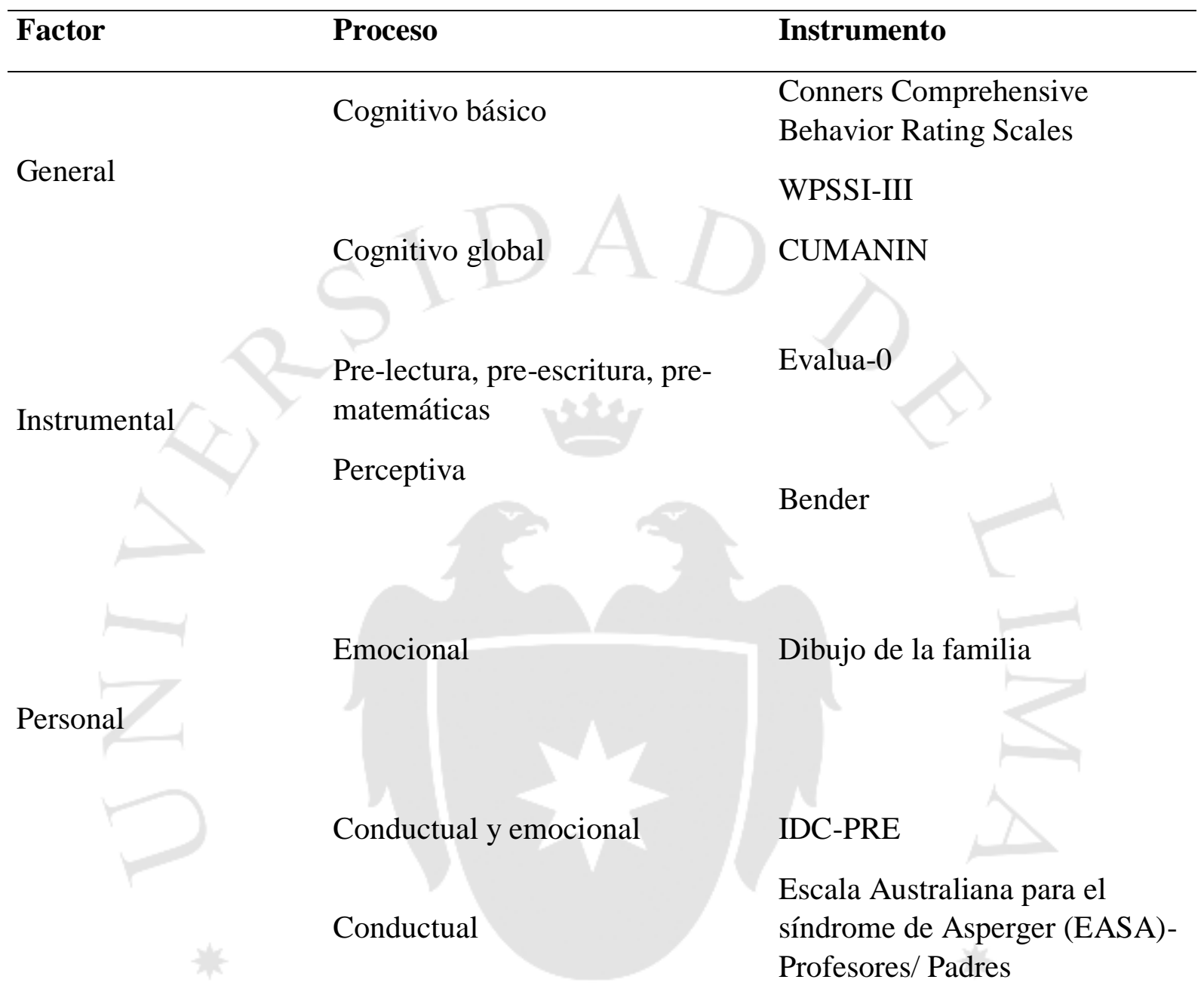

\subsubsection{Ficha técnica de Instrumentos}

\subsubsection{Conners Comprehensive Behavior Rating Scales- Revised. Long version}

\section{(CPRS-R:L)}

- Autor: C. Keith Conners, 2008

- Administración: Individual

- Duración: Aproximadamente 20 minutos

- Aplicación: 3 años a 17 años, 11 meses 
- Significación: Evalúa el comportamiento, las emociones y los problemas académicos en niños y adolescentes

- Descripción: Consta de dos formularios: Formularios de Maestros y Padres (edades 3-17 años). En ambas escalas se encuentran los siguientes factores: Psicopatología general, inatención, hiperactividad/impulsividad, problemas de aprendizaje, funcionamiento, oposicionismo-desafiante, labilidad emocional, ansiedad-timidez, perfeccionismo, problemas sociales, rasgos psicosomáticos.

- Adaptación de baremos: Refleja el Censo 2000 de EE.UU. en términos de género, raza / origen étnico y nivel de educación de los padres

- Confiabilidad:

Consistencia interna: Alpha ente 0.77 y 0.96

Confiabilidad temporal: Coeficiente entre 0.47 y 0.88

- Validez:

Contenido: las escalas se derivan en su mayoría de síntomas de diferentes trastornos según definidos en DSM III, IIIR y IV.

Constructo: Análisis factorial (seis sub-escalas que miden distintas dimensiones de los problemas de conducta y psicopatologías fueron desarrolladas, encontrando una correlación de leve a moderada.)

- Sistema de calificación: Las puntuaciones directas se convierten en puntuaciones $\mathrm{T}$ de acuerdo con la tabla de perfiles que es específica para la edad y el sexo del niño que está siendo evaluado. La hoja de perfil indica escalas basadas en una muestra normativa de niños en el grupo de edad y género.

\subsubsection{WPPSI-III- Escala de Inteligencia de Wechsler para pre-escolar y} primaria.

- Autor: David Wechsler, 2009

- Administración: Individual

- Duración: Entre 30 y 35 minutos los 4 tests principales de la 1era.etapa (2:6 a $3: 11)$ y entre 40 y 50 minutos los 7 tests principales de la 2 da.etapa

- $\quad$ Aplicación: Niños entre los 2 años y 6 meses y los 7 años y 3 meses

- Significación: Medida de la inteligencia: Cociente General de Inteligencia. En la versión de 2:6 - 3:.11años se evalúa las áreas de Cociente Verbal, Manipulativo 
y Velocidad de procesamiento, Lenguaje general es opcional. En el protocolo de 4:0 - 7:3 años se evalúa Cociente Verbal, Manipulativo y Velocidad de procesamiento, Lenguaje general es opcional.

- Material: Manual, cuadernillo, hoja de respuesta, platillas de corrección, cubos.

- Descripción:

○ Factor Verbal:

a) Información: Capacidad de adquirir, conservar y recuperar conocimientos referidos a hechos generales. Capacidad del sujeto para interiorizar información de su entorno y retenerla para un uso posterior. Atención, memoria a largo plazo, la comprensión y expresión verbal.

b) Vocabulario: Capacidad para la formación de conceptos verbales y el nivel de comprensión de las palabras. Conocimientos generales, potencial de aprendizaje y grado de desarrollo del lenguaje.

c) Adivinanzas: Capacidad de Razonamiento verbal, analógico y general. También la capacidad de integrar y sintetizar distintos tipos de información, así como la generación de conceptos alternativos.

d) Comprensión: Nivel de expresión y comprensión verbal, capacidad de razonar delante ciertas situaciones sociales, el juicio social, sentido común y madurez.

(Opcional) e) Semejanzas: Capacidad para la conceptualización. Potencial de aprendizaje del niño.

○ Factor Manipulativo:

a) Cubos: Capacidad del niño para analizar y sintetizar estímulos visuales abstractos.

b) Matrices: Capacidad del niño para procesar la información visual y la aptitud de razonamiento abstracto.

c) Conceptos: Capacidad para el razonamiento abstracto y la formación de categorías.

(Opcional) d) Figuras Incompletas: Percepción y organización visual, concentración y capacidad de reconocimiento visual de los elementos esenciales de un objeto. 
(Opcional) e) Rompecabezas: Organización visoespacial, integración en las relaciones entre una parte y el todo, razonamiento no verbal, aprendizaje por ensayo error.

- Factor Velocidad de Procesamiento:

a) Búsqueda de Símbolos: Agilidad mental

b) Claves: rapidez en la coordinación-visomotora

○ Factor Lenguaje General:

(Opcional) a) Dibujos: Evalúa aspectos importantes como la capacidad para entender instrucciones verbales, la discriminación visual y auditiva. La ejecución en esta prueba viene también influida por la memoria fonológica y la de trabajo.

(Opcional) b) Nombres: Evalúa el lenguaje expresivo del niño. También la recuperación de las palabras adecuadas en la memoria a largo plazo y la asociación de los estímulos visuales con el lenguaje.

- Adaptaciones o Baremos: Tipificación con una muestra representativa de la población infantil española compuesta por 1,220 niños procedentes de diversas regiones

- Confiabilidad: (tipificación española): Coeficientes de fiabilidad de los test oscilan alrededor de 0.83 , con un mínimo de 0.76 (Vocabulario) y un máximo de 0.89 (Semejanzas). Coeficientes de fiabilidad de los índices del WPPSI-III: oscilan entre 0.87 (Lenguaje general) y 0.94 (CI Total).

Coeficientes de estabilidad en los diferentes test: 0.83 . Valor excelente en el test Nombres (valor superior a 0.90); muy satisfactorio en los test Cubos, Información, Vocabulario, Búsqueda de símbolos, Adivinanzas, Claves, Comprensión, Figuras incompletas, Semejanzas y Dibujos (valor superior a 0.80), y es adecuado en los test Matrices, Conceptos y Rompecabezas (valor superior a 0.70$)$.

Coeficientes de estabilidad de los índices del WPPSI-III: excelentes (CI Verbal, CI Total e índice de Lenguaje general) o muy satisfactorios (CI Manipulativo e índice de Velocidad de procesamiento).

- Validez: 
Contenido: Los ítems y los tests cubren un amplio rango de áreas cognitivas, incluidos el razonamiento verbal, la formación de conceptos, el procesamiento secuencial, la compresión auditiva, la flexibilidad cognitiva, el juicio social, la organización perceptiva y la velocidad de procesamiento psicomotor (Cooper, 1995; Kaufman, 1975, 1994; Sattler, 2001).

Constructo: Análisis factorial (reactivos correlacionan y se agrupan alrededor de un amplio rango de áreas cognitivas en la niñez).

- Calificación: Cada ítem de las subpruebas obtiene un puntaje de 1 o 2 puntos dependiendo de la dificultad. Al final, se suman todos los puntajes de cada subprueba y se convierten en puntaciones escalares. A partir de las puntaciones escalares se obtiene los cocientes verbal y manipulativo y velocidad de procesamiento y lenguaje general.

\subsubsection{Cuestionario de Madurez Neuropsicológica Infantil}

- Autor: Portellano, J. Mateos, R. y Martínez, R., 2000

- Administración: Individual

- Duración: Aproximadamente entre 30 y 50 minutos

- Aplicación: Niños de 3 a 6 años

- Significación: Evaluar el grado de madurez neuropsicológica alcanzada por el niño y la posible presencia de signos de disfunción cerebral.

- Descripción:

○ Escalas principales:

a) Psicomotricidad: evalúa motricidad fina y gruesa.

b) Lenguaje articulatorio: Repetición de palabras con dificultad articulatoria creciente.

c) Lenguaje comprensivo: recuerdo y comprensión de una historia contada.

d) Lenguaje expresivo: Repetición de frases con dificultad creciente

e) Estructuración espacial: orientación espacial

f) Visopercepción: reproducción y copia de figuras geométricas

g) Memoria icónica: memoria visual

h) Ritmos: memoria auditiva 
- Escalas auxiliares

a) Atención: atención sostenida y discriminación visual.

b) Fluidez verbal: capacidad de formar frases a partir de palabras dadas

c) Lectura: palabras y frases de dificultad creciente

d) Escritura: dictado

e) Lateralidad: predominio de ojo, mano y pie

- Adaptaciones o Baremos: Habilidades neuropsicológicas verbales y no verbales Edad perceptiva para cada sub-área y PC.

- Confiabilidad:

Consistencia interna: Alpha se encuentran dentro de un rango de 0.52 (Memoria) a 0.90 (Visopercepción).

- Validez:

Contenido: Diseñado a partir de sólidas bases teóricas y experimentales de la neuropsicología.

Criterio: Se correlacionó las puntuaciones de sus compuestos y subpruebas con las puntuaciones totales.

Constructo: Los resultados del análisis factorial proporcionaron un factor único con un valor específico que mide "la percepción visual total"

- Sistema de calificación:

Se le brinda un punto por cada ítem bien resulto. Al final se suman los puntajes de cada prueba y se identifica en qué PC se encuentra, su edad maduracional y los Cocientes de habilidades neuropsicológica verbales y no verbales

\subsubsection{Batería psicopedagógica Evalúa-0}

- Autor: Daniel Gonzales Manjón, Jesús García Vidal, 2000

- Administración: Individual

- Duración: 25 minutos aproximadamente

- Aplicación: Niños de 4 - 5 años

- Significación: Rendimiento psicopedagógico

- Descripción:

La batería está formada por:

- Capacidades cognitivas 
a) Clasificación: Valora la capacidad para inducir categorías a partir de estímulos visuales, comprobando su habilidad para detectar que elementos del grupo no pertenecen a la misma categoría.

b) Series: Valora la habilidad para ordenar conjuntos de elementos, teniendo en cuenta una de sus características.

c) Letras y números: Valora la capacidad para reconocer símbolos convencionales que son dictados verbalmente por el aplicador, teniendo el alumno que localizarlos en una lámina.

d) Memoria verbal: A partir de estímulos verbales, se valora la capacidad del evaluado para realizar tareas de recuerdo, apreciándose de esta manera la memoria verbal a corto plazo.

e) Organización perceptiva: Valora la capacidad del evaluado para componer un puzles a partir de sus piezas y del modelo correspondiente.

Capacidades lingüísticas

a) Recepción auditiva y articulación: Valora la capacidad para discriminar palabras fonéticamente parecidas como el nivel de eficiencia del registro fonológico de los evaluados.

b) Palabras y frases: Se evalúa las habilidades léxicas de la evaluada mediante tareas referidas a palabras y frases, como completar frases, detectar errores en frases, establecimiento de relaciones causales, sinónimos y antónimos.

c) Habilidades fonológicas: Evalúa las capacidades que se relacionan con la conciencia lingüística que posee la evaluada, mediante la realización de tareas de: conciencia silábica y conciencia fonética.

- Capacidades espaciales:

a) Copia de figuras: Se pretende valorar el grado de desarrollo de las habilidades necesarias para la copia de dibujos.

b) Grafomotricidad: Se pretende valorar el estado de las habilidades grafomotrices que resultan necesarias para comenzar la enseñanza de los procesos de escritura.

- Área emocional

a) El test de la Familia de Corman: adaptación 
b) Test palelográfico: Organización y tolerancia a la frustración, fatiga

c) Cuestionario de familia

- Adaptaciones o Baremos: Baremos escolares en PC

- Confiabilidad: Consistencia interna: Alpha entre 0.73 (Di. Simples) y 0.77 (Esquemas)

- Validez:

Contenido: Los ítems cubren un amplio rango de áreas cognitivas, incluidos el razonamiento verbal, clasificación, atención-concentración, memoria, la compresión auditiva, ortografía y grafía, organización espacial y articulación.

Constructo: Análisis factorial (reactivos correlacionan y presentan una varianza que se entiende como un factor cognitivo general, que está incluido en todas las actividades propias de la educación infantil.

- Sistema de calificación:

Se le brinda un punto por cada ítem bien resulto. Al final se suman los puntajes de cada prueba y luego se ubican dentro de un rango PC.

\subsubsection{BENDER- Test Guestáltico Visomotor}

- Autor: Lauretta Bender, 1983

- Administración: Individual

- Duración: Aproximadamente 15 minutos

- Aplicación: Niños entre 5 y 10 años, 11 meses. También en pacientes con problemas neurológicos y psiquiátricos

- Significación: Evalúa los defectos cerebrales orgánicos, la pérdida de función, el retardo, la regresión en niños y adultos, así como las desviaciones de la personalidad en fenómenos de regresión.

- Descripción: Es un test no-verbal, consiste en la copia de una serie de nueve formas geométricas de las diez seleccionadas por Wertheimer. Posee un valor clínico para la exploración del desarrollo de la inteligencia infantil y en el diagnóstico de los diversos síndromes clínicos de deficiencia mental, afasia, desórdenes cerebrales orgánicos, psicosis mayores, simulación de enfermedades y psiconeurosis, puede emplearse además como un test proyectivo.

- Adaptaciones o Baremos: Edad de maduración perceptivo-motora. 
- Confiabilidad:

Consistencia interna: Alpha más de 0.80

Confiabilidad temporal: 0.79 en pacientes con alteraciones neuropsiquiátricas, 0.66 para pacientes con Enfermedad de Alzheimer y desde 0.57 a 0.63 para adultos mayores.

Confiabilidad entre jueces: van de 0.70 a 0.86 (Ciccheti, 1994).

- Validez:

Método: Se toma como criterio el diagnóstico hospitalario del paciente que incluye pruebas paraclínicas, además del juicio del examinador, independientemente del nivel de experiencia del aplicador y porcentajes de entre 82 y $86 \%$, con un promedio de diagnósticos correctos del $84 \%$.

Constructo: Análisis factorial (reactivos correlacionan y se agrupan alrededor de síndromes que corresponden a varias dimensiones de trastornos en la niñez).

- Sistema de calificación:

Según el protocolo de corrección y la calidad de las reproducciones de los dibujos. A menos cantidad de errores de copia menor probabilidad de lesión cerebral o daño neurológico. Se compara la cantidad de errores con lo aceptado según la edad.

\subsubsection{El Test de Dibujo de la Familia}

- $\quad$ Autor: Joseph Ma. Luis Font, 1978

- Administración: Individual

- Duración: No tiene tiempo límite, pero aproximadamente 10 minutos

- Aplicación: Niños hasta los 9 años

- Significación: Evalúa las áreas afectivas con relación al entorno familiar

- Descripción: Es una de las técnicas de diagnóstico de la afectividad infantil más ricas en contenido. Facilita la exploración de las vivencias conflictivas del niño, que de una u otra forma siempre guardan relación con los elementos de la familia.

- Sistema de calificación: Cualitativo, según las características del dibujo, orientación en el espacio, orden de los personajes y las respuestas a las preguntas.

\subsubsection{Inventario de Comportamiento Preescolar (IDC-PRE)}


- Autor: José J. Bauermesiter, 1994

- Administración: Individual a tutores y maestros del niño

- Duración: Aproximadamente 20 minutos

- Aplicación: 4 -5 años

- Significación: Ayudar a entender cómo se desenvuelve el niño en el salón de clases.

- Descripción: Se divide en las siguientes escalas descriptivas: Retraimiento social / Depresión, Ansiedad, Actividad / Impulsividad / Distracción, Irritabilidad / Hostilidad.

- Confiabilidad:

Consistencia interna: Alpha ente 0.82 a 0.95.

Confiabilidad temporal: Coeficiente entre 0.57 (destrezas sociales) y 0.98 .

Confiabilidad entre jueces: 0.22 (ansiedad) a 0.84 (Ret. Social. /Dep)

- Validez:

Contenido: las escalas se derivan en su mayoría de síntomas de diferentes trastornos según definidos en DSM III, IIIR y IV.

Constructo: Análisis factorial (reactivos correlacionan y se agrupan alrededor de síndromes que corresponden a varias dimensiones de trastornos en la niñez)

- Sistema de calificación: Se suman las puntuaciones y se convierten puntuaciones crudas a puntuaciones $\mathrm{T}$ y rangos PC. Se desarrollaron normas por género.

\subsubsection{Escala Australiana para el Síndrome de Asperger (EASA)-Profesores o} $\underline{\text { Padres }}$

- Autor: Tony Attwood, 1998

- Administración: A los padres y maestros del niño.

- Duración: Aproximadamente 20 minutos

- Aplicación: Niños en edad escolar

- Significación: Identifica comportamientos y habilidades que puedan ser indicativos del Síndrome de Asperger en niños durante sus años en la escuela primaria.

- Descripción: Consta de un formulario que incluyen preguntas sobre aspectos sociales, académicos y emocionales del niño

- Fiabilidad: interjueces y test-retest 
- Validez:

Contenido: las escalas se derivan en su mayoría de síntomas de los trastornos de asperger y autismo de alto funcionamiento según definidos en DSM IV -TR y el CIE -10 .

- Sistema de calificación: En la Escala Australiana para el Síndrome de Asperger el "0" significa que el niño no presenta ninguna anomalía cuando lo comparamos con otros niños de su edad. Cuanto más se aparte de la normalidad, más nos acercaremos a la puntuación 6. Si la respuesta a la mayoría de las preguntas de la Escala Australiana para el Síndrome de Asperger es mayor de 0, y la puntuación media está entre 2 y 6 (es decir, visiblemente por encima del nivel normal), no se puede indicar, de manera automática, que el niño tiene Síndrome de Asperger. Sin embargo, existe dicha posibilidad, y se justifica que se le realice una valoración diagnóstica por parte de un profesional de la salud.

\subsection{Procedimiento}

A continuación se describe el proceso de recolección de información:

1. Reunión de entrega y explicación del consentimiento informado y la confiabilidad con los padres.

2. Entrevista de motivo de consulta con los padres

3. Entrevista de Historia Clínica con los padres (dos sesiones)

4. Entrega de cuestionarios a maestros y padres con el fin de indagar las conductas perturbadoras en casa y en el colegio.

5. Observación de conducta de tipo narrativa en el ambiente escolar. Se realizara dos sesiones con el fin de observar las conductas problema tanto en el aula de clases como en el recreo.

6. Evaluación integral del niño: emocional, intelectual, psicopedagógica, conductual y perceptual.(10 sesiones)

7. Reunión de devolución de resultados a padres

8. Formulación de plan de trabajo según los resultados

9. Evaluación de la efectividad del plan de trabajo

10. Informe final 


\section{RESULTADOS}

\subsection{Anamnesis}

\subsubsection{Datos Generales}

- Nombres y Apellidos: Salomón R.

- Sexo: Masculino

- Edad: 5 años, 10 meses

- Lugar y fecha de nacimiento: 08 de enero del 2009

- Tiempo de residencia en Lima: 5 años, 10 meses

- Estado civil: Soltero

- Grado de instrucción: Kínder

- Ocupación actual: Estudiante

- Religión: Católica

- Idiomas: español

- Con quién(es) vive: Madre y hermana mayor

- Número de hermanos: 1

- Posición ordinal: 2/2

- Informantes: Paciente, madre y padre

- Fechas de las entrevistas: Entrevistas con los padres: 30 octubre del 2013

Entrevista con el niño: 6, 13, 20 y 27 de noviembre y 4, 11 y 18 de diciembre del 2013. Además 5, 12, 19 de Marzo del 2014.

- Lugar de la entrevista: Instituto latinoamericano del comportamiento

- Evaluador: Mariana Morales 


\subsubsection{Motivo de consulta}

Los padres de Salomón recurren al Centro solicitando una evaluación integral y descarte del Trastorno por Déficit de Atención con Hiperactividad por sugerencia del centro educativo.

\subsubsection{Problema actual}

Ellos comentan que el niño "se pierde" en su propio mundo. No logra prestar atención a las cosas, ni al profesor ni a sus compañeros. En casa no puede mantenerse quieto, se para se da vuelta y regresa cuando está almorzando, repitiendo está secuencia consecutivamente. Cuando lo han puesto en clases alternas deportivas también se aísla o hace lo que quiere. Es muy ordenado y no le gusta que le cambien su orden. Es impositivo y desea ser atendido inmediatamente.

Esta situación ocurre tanto en casa como en el colegio, sucede todos los días a la hora de clase o en el recreo. Presenta dificultades en sus relaciones sociales, aislándose, juega solo en el recreo debido a que no comprende las reglas del juego o no le gusta lo que los otros niños juegan, le cuesta socializar con sus pares. Se le dificultan las actividades que requieren habilidades motoras y realizar trabajos escolares, distrayéndose constantemente y parándose de su asiento. Los padres sospechan que tiene un problema pero no saben cuál es la causa. Esperan que con la evaluación poder saber las causas de su problema y con la posterior terapia, pueda mejorar sus habilidades sociales, logre organizarse mejor y concentrarse en clase.

\subsubsection{Desarrollo cronológico}

Desde que comenzó a caminar al año y 3 meses se mostraba inquieto. Conforme fue creciendo se fue volviendo más inquieto y desatento, se concentraba mucho en las tareas de su agrado y no se percataba de lo que sucedía a su alrededor, le costaba realizar actividades motoras y de conciencia espacial. Además, realizaba rituales cuando estaba muy emocionado, agitando las manos y caminando en puntas de pies. Con las terapias estas conductas han disminuido. Ya es capaz de mantener contacto visual, los rituales se han disminuido casi por completo y ha logrado mejoras 
en sus habilidades motoras y conciencia espacial. Ya logra expresar su afecto con personas que no son sus familiares cercanos y socializar con niños de su edad, siendo capaz de mantener una conversación corta.

\subsubsection{Historia personal}

Salomón es el segundo hijo de una pareja joven, nació por cesárea a los 8 meses y medio. El embarazo tuvo un transcurso regular, sin mayores perturbaciones. La madre recuerda haber presentado una placenta "vieja". Ella refiere que al nacer el niño presentó un APGAR de 8 al primer minuto y 10 al segundo minuto. La madre le dio de lactar durante los tres primeros meses, en este tiempo catalogó la succión de bebe como de intensidad leve. Durante su etapa de crecimiento, Salomón presentó un desarrollo motor y del lenguaje dentro de lo esperado. Sin embargo, en ocasiones repite varias veces la primera palabra de una frase hasta que se organiza y puede terminar la oración fluidamente. Esto sucede cuando está muy emocionado. Además, todavía le cuesta establecer contacto visual cuando se le habla y responder por su nombre, pareciendo no escuchar, sobre todo cuando está muy concentrado en una actividad de su agrado.

Por otro lado, desde pequeño se mostraba inquieto, es por esto que a los 2 años tuvo un accidente en el cual se rompió un diente. Asimismo, caminaba en puntitas de pies pero con el tiempo fue disminuyendo hasta desaparecer casi por completo. Además, realizaba movimientos con las manos y brazos, sacudiéndolos $\mathrm{o}$ estrujándolos cuando estaba muy emocionado o molesto, los cuales también han ido disminuyendo presentándose en ocasiones muy limitadas.

Con respecto a su control de esfínteres, a los 3 años logró controlar las heces. No obstante, todavía le cuesta controlar la orina en las noches, llegando a mojar la cama actualmente. En estas ocasiones los papás le reclaman de una manera calmada.

En lo referente a sus hábitos de sueño, Salomón todavía duerme acompañado, tanto en su cama como en la de su madre y se despierta en las noches llamando a su mamá si es que no la encuentra con él. Además presenta miedo a la oscuridad, pidiendo que le prendan la luz antes de entrar a un cuarto oscuro o para dormir.

Desde pequeño Salomón es muy sensible al sonido, le molestan los ruidos fuertes y el tumulto. En estas ocasiones, se tapa los oídos. 
Salomón comenzó su historia escolar ingresando al nido a los 2 años. Logró adaptarse sin dificultades. Luego ingresó al pre kínder de un colegio privado de nivel socioeconómico medio. Nunca ha repetido ningún grado escolar, ni ha sido cambiado de colegio.

Salomón ha participado a lo largo de su etapa pre-escolar de varias terapias como psicomotricidad, de socialización, de regulación en terapia de grupo y de atención.

Es capaz de acercarse a otros niños desconocidos y conversar con ellos. Se ríe de las bromas de otros y comparte sus juguetes sin dificultad. No obstante, prefiere los juegos solitarios por lo que le cuesta integrarse en el juego de otros niños. En el colegio juega solo en el recreo, mientras que otros niños juegan a su alrededor.

Los padres de Salomón están separados desde febrero del 2013 pero mantienen una relación amistosa y continúan en comunicación permanente para coordinar sobre sus hijos. Salomón tomó la separación con calma, solo se ha vuelto más posesivo con su madre desde ahí pidiéndole que no salga en las noches. Los niños viven en casa de la madre y ella es quien pone las pautas de conducta. Si Salomón realiza una conducta inadecuada se habla con él y lo entiende y se le brinda un incentivo por las conductas adecuadas.

Por otro lado, presenta astigmatismo, usando lentes permanentes en la actualidad.

Salomón es un niño alegre, sociable y cariñoso. No obstante, en ocasiones es terco y resentido cuando se molesta o quiere algo, en estas ocasiones reacciona llorando. Es impulsivo, poco paciente e inquieto.

Salomón realiza Karate y natación dos veces por semana y asiste a talleres de acuturier desde los 4 años y de atención una vez por semana desde hace un año, estando a punto de ser dado de alta del primero.

En el 2014 fue diagnosticado con Trastorno por déficit de atención por Hugo Díaz.

En lo referente a enfermedades familiares, en la familia materna existe un pariente con autismo y en la paterna existen posibles antecedentes de TDAH (padre). 
Tabla 5. 1

Antecedentes relevantes

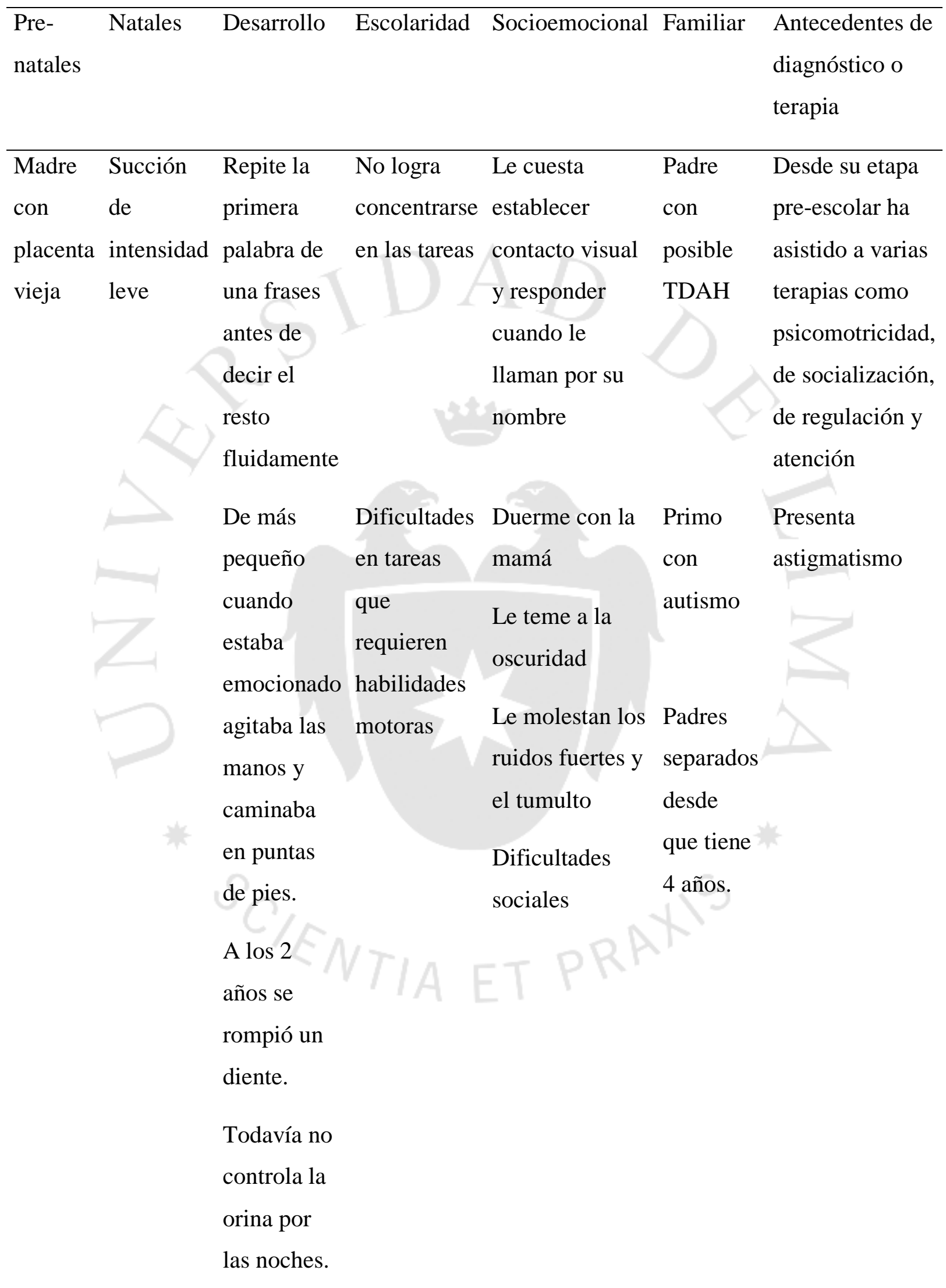


5.1.6 Historia familiar

\section{PADRES}

A. Padre

a. Datos de filiación:

- Nombre y apellidos: Raúl

- Sexo: Masculino

- $\quad$ Edad 44 años

- Lugar y fecha de nacimiento: Lima, 01 de junio de 1970

- Tiempo de residencia en Lima: toda su vida

- Estado civil: separado

- Grado de instrucción: universitaria completa

- Ocupación actual (centro de trabajo y cargo): abogado, Estudio de abogados

- Religión: Católica

b. Características personales: Es un padre muy preocupado por sus hijos, los visita constantemente y sale con ellos. Presenta tics motores en el cuello. Es una persona ansiosa, alegre y conversadora.

c. Relación del paciente con su padre: Buena. Se ven interdiario

B. Madre

a. Datos de filiación:

- Nombre y apellidos Marife

- Sexo: Femenino

- $\quad$ Edad: 36

- Lugar y fecha de nacimiento: Lima, 15 de diciembre de 1977

- Tiempo de residencia en Lima: toda su vida

- Estado civil: separada

- Grado de instrucción: universitaria completa

- Ocupación actual (centro de trabajo y cargo): Abogada, Estudio de abogados

- Religión: Católica

b. Características personales: Es una madre preocupada por sus hijos, se siente muy culpable por no atender a Salomón a causa de sus largas horas de trabajo. Es una persona cariñosa y paciente. 
c. Relación del paciente con su padre: Buena. Vive con ella

\subsection{Resultados de la evaluación}

PRIMERA FASE: 4años, 7 meses

\subsubsection{Factores Generales}

i. Proceso cognitivo global

\section{A. WPSSI-III}

a. Observación de conducta

Cuando fue evaluado en el área de cognitiva, se mostró inquieto, le costó esperar, distrayéndose fácilmente. Cantaba o hablaba de temas que no tenían relación con la tarea. Asimismo, se observó la presencia de rituales como levantar las manos a la altura de los hombros y agitarlas repetidamente mirándolas abriendo más los ojos, por periodos de 5 segundos. Se evidenció interés y esmero en lograr un buen trabajo, mostrando una actitud amable y colaboradora, respondiendo de inmediato cuando le interesaba la tarea. Presenta un amplio uso del lenguaje con algunas dificultades en la denominación de palabras, demorándose en encontrar las palabras adecuadas para expresar lo que deseaba.

b. Datos cuantitativos

Esta puntuación compuesta representa el funcionamiento intelectual en dominios específicos, en el caso de Salomón los hallazgos fueron los siguientes: 
Tabla 5.2

Resultados de CI, Puntuación compuesta

\begin{tabular}{llll}
\hline Escala & CI / PC & Rango PC & Categoría \\
\hline Verbal & 100 & 50 & Medio \\
Manipulativa & 114 & 83 & Medio alto \\
Velocidad de Procesamiento & 78 & 7 & Inferior \\
Total & 101 & 53 & Medio \\
Lenguaje General & 134 & 99 & Muy superior \\
\hline
\end{tabular}

Figura 5. 1

Perfil del WPSSI-III

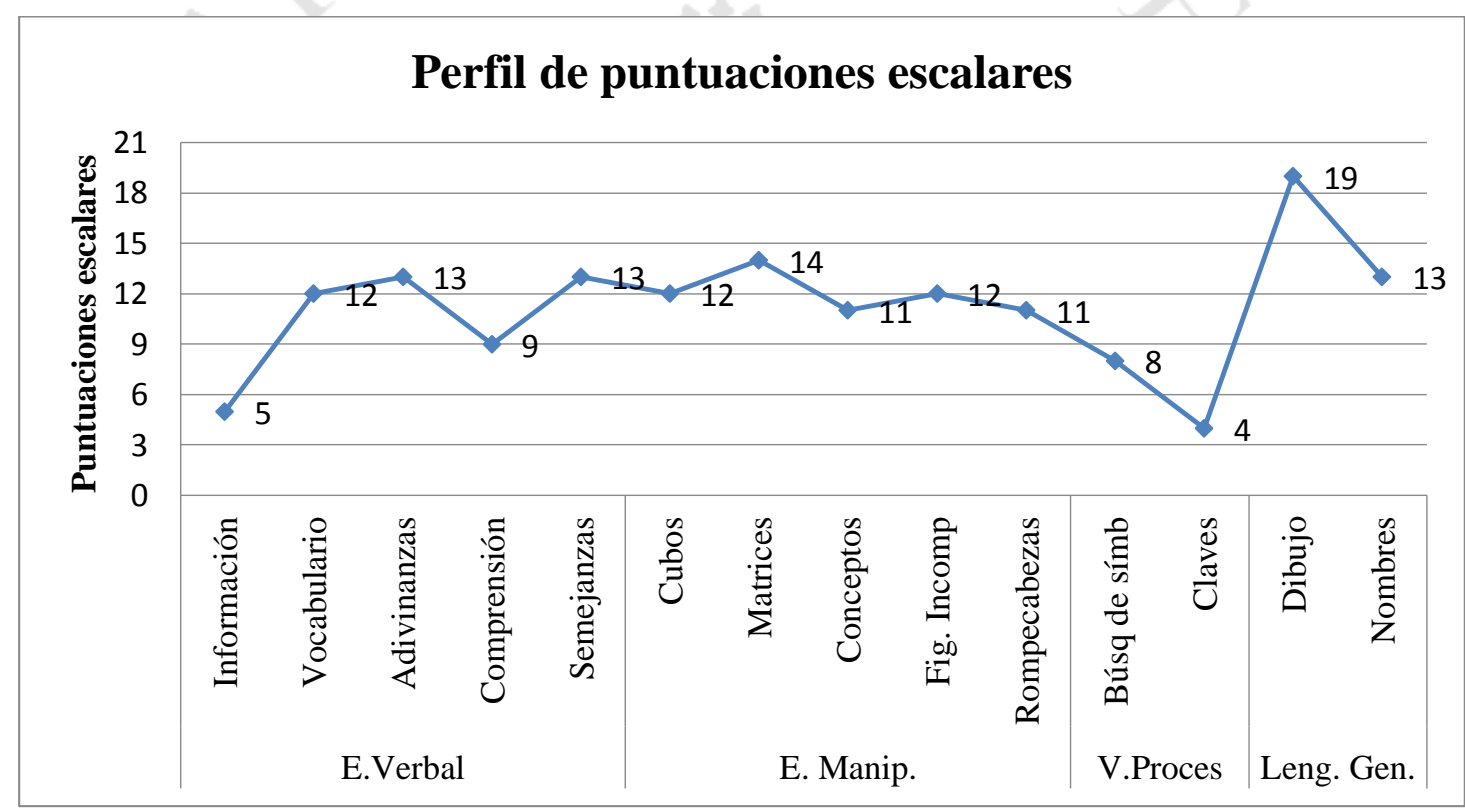

c. Datos cualitativos

En la evaluación cognitiva realizada encontramos que Salomón obtiene un CI Total de 101 (Medio) que indica que se encuentra en un adecuado punto de desarrollo en el momento de la evaluación de las áreas exploradas, comparándolo con los niños de su misma edad. Se observa un Coeficiente Verbal 100 (Medio) y un Coeficiente Manipulativo de 114 (Medio Alto). Por otro lado, en Velocidad de Procesamiento su performance es de 78 (Inferior). 
La Escala Verbal, se encuentra formada por diversas áreas donde mencionaremos a la Información Verbal, que es una medida de la capacidad del sujeto para interiorizar información de su entorno y retenerla para un uso posterior. La atención, la memoria a largo plazo, la comprensión y expresión verbal también forman parte de las habilidades requeridas en este test. Salomón se encuentra dentro de la nivel Promedio. Se observó una adecuada formación de conceptos y razonamiento verbal. Asimismo, se identificó que posee la capacidad de razonamiento analógico y general, así como habilidad para integrar y sintetizar distintos tipo de información, abstracción verbal, conocimiento general y capacidad de generar conceptos alternativos.

No obstante, presenta un pobre desempeño para adquirir, conservar y recuperar conocimientos referidos a hechos generales, los cuales se relacionan con la memoria a largo plazo y aptitud para recordar y recuperar información extraída de su entorno.

En la Escala Manipulativa, conformada por actividades de razonamiento perceptual, que requieren que el evaluado examine y piense acerca de diseños y dibujos y resuelva problemas sin usar palabras, Salomón logra un buen desempeño en la ejecución de tareas visuales y al realizar actividades de abstracción, análisis y síntesis perceptuales. Asimismo, se observa una alta capacidad para establecer relaciones lógicas entre un grupo de elementos y una performance acorde a su edad cronológica en las tareas de organización y percepción de detalles. En general, las habilidades de Salomón para resolver problemas no verbales de manera rápida y eficiente con información visual están en un nivel Medio Alto. Destaca su capacidad para formar y reconocer conceptos, hacer inferencias, comprender implicaciones, resolver problemas, generalizar y razonar.

En la Escala de Velocidad de Procesamiento, el cual mide la habilidad para procesar una información visual simple de forma rápida y eficaz y dar una respuesta, presentó un desempeño por debajo de lo esperado para su edad cronológica, lo cual se evidencia en su rendimiento en los diferentes subtests. Así tenemos que presenta limitaciones en tareas que requieran velocidad procesamiento y memoria a corto plazo, presentando dificultades en su capacidad de aprendizaje, percepción visual, coordinación viso-manual, flexibilidad cognitiva, atención y motivación. Esto ubica a Salomón dentro de un nivel Inferior al promedio, siendo su capacidad general para explorar, ordenar o discriminar información visual simple Normal Inferior. 
En lo referente a la Escala de Leguaje General, se evidencia fortalezas en su capacidad de comprender instrucciones verbales, discriminación auditiva y visual, memoria y procesamiento auditivo y su integración de la percepción visual con estímulos auditivos. Asimismo, se observa una alta capacidad de lenguaje expresivo, recuperación de palabras de la memoria a largo plazo y asociación de los estímulos visuales con el lenguaje. Esto ubica a Salomón dentro de esta área en un nivel Muy superior al promedio.

\section{B. CUMANIN}

a. Observación de conducta

Al realizar los ejercicios de esta sección, Salomón se mostró entusiasta y colaborador, realizando de forma rápida las tareas propuestas. No obstante, al momento de realizar las copias, presentó una actitud poco paciente y descuidada, presentando trazos poco precisos.

b. Datos cuantitativos

En sus Habilidades Cognitivas encontramos los siguientes resultados:

Tabla 5.3

Resultados de CUMANIN

\begin{tabular}{llll}
\hline ESCALAS & PD & PC & CATEGORIA \\
\hline Psicomotricidad & 5 & 10 & Inferior \\
Lenguaje Articulatorio & 12 & 50 & Promedio \\
Lenguaje Expresivo & $3 /$ & 60 & Promedio \\
Lenguaje Comprensivo & 7 & 90 & Superior \\
Estructura Espacial & 13 & 99 & Superior \\
Viso-percepción & 7 & 55 & Promedio \\
Memoria Icónica & 6 & 60 & Promedio \\
Ritmo & 2 & 45 & Promedio \\
Fluidez verbal & 20 & 80 & Superior \\
Atención & 4 & 10 & Inferior \\
\hline
\end{tabular}




\section{Continuación Tabla 5.3}

\begin{tabular}{lccl}
\hline Desarrollo Global & 55 & 65 & Promedio \\
Desarrollo Verbal & 22 & 70 & Superior \\
Desarrollo No verbal & 33 & 70 & Superior \\
\hline Cociente de Desarrollo & 104 & Promedio
\end{tabular}

Figura 5.2

Perfil Cumanin

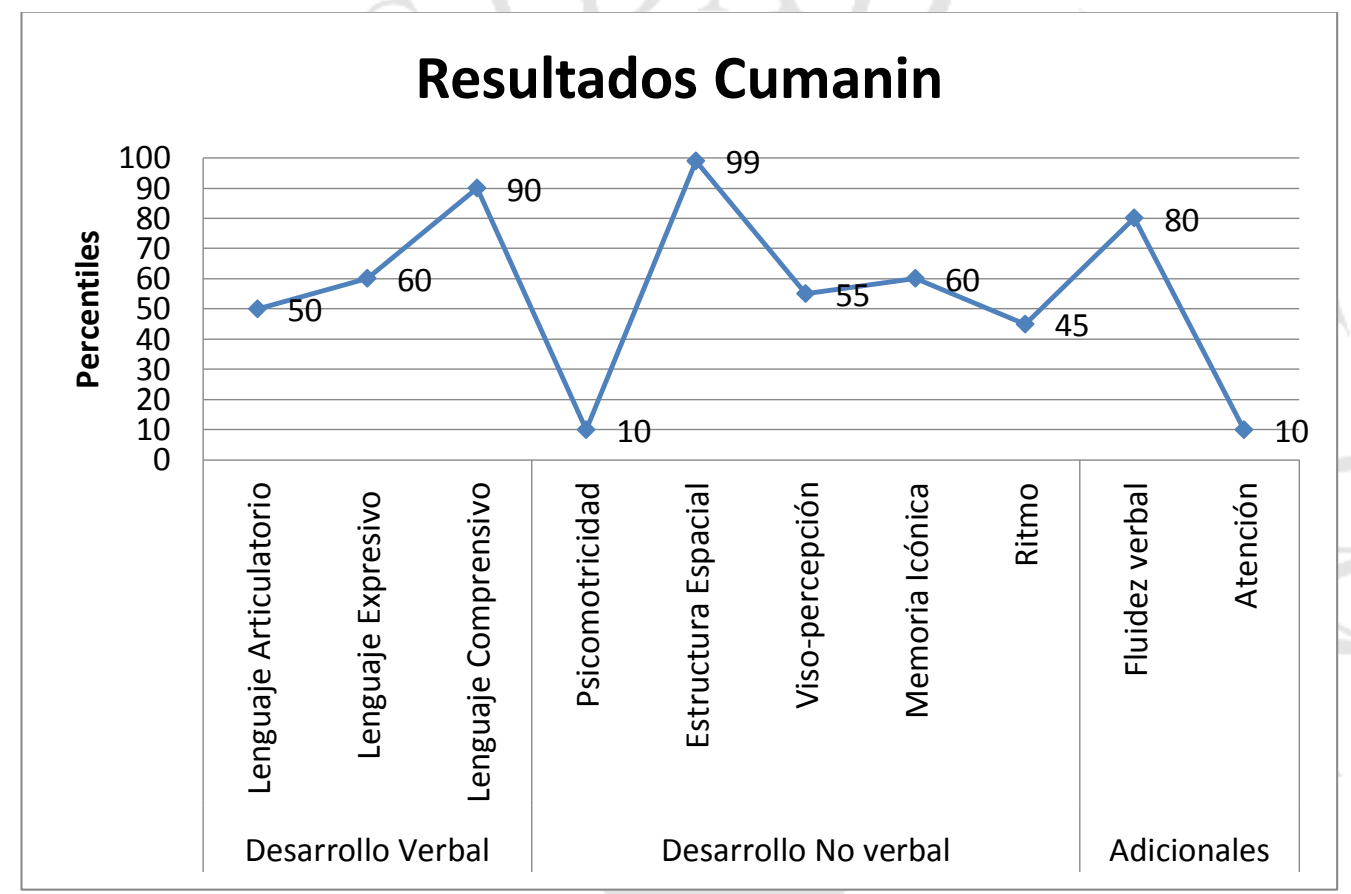

c. Datos cualitativos

Salomón posee un Cociente de Desarrollo de 104 (Promedio) en donde su Desarrollo Verbal alcanza un percentil de 70 (Superior), similar desempeño se encuentra en el Desarrollo No Verbal (PC 70) mientras que en el desarrollo global se ubica en una categoría promedio (PC 65). En cuanto a las áreas específicas, exhibe mejores recursos en Estructura Espacial (PC 99), Lenguaje Comprensivo (PC 90), seguida de fluidez verbal (PC 80), ubicándose en la categoría superior. Asimismo, se observa recursos de acuerdo a su edad en Lenguaje expresivo, Memoria Icónica (PC 60), vispercepción (PC 
55), lenguaje articulatorio (PC 50) y en ritmo (PC 45). Encontraste se localizan las áreas de psicomotricidad y atención (PC 10) por ubicarse en la categoría inferior.

En las escalas principales se encuentra un Desarrollo verbal heterogéneo, con mejores recursos en Lenguaje Comprensivo, donde logra seguir instrucciones simples y semicomplejas y responder debidamente preguntas con respecto a un texto presentado, ubicándose en una categoría superior. Por otro lado obtiene un desempeño promedio en Lenguaje Articulatorio y Lenguaje Expresivo, presentando dificultades en la repetición de palabras compuestas y largas. Además se observa el fenómeno de extensión del estímulo, costándole repetir oraciones de complejidad y extensión creciente.

Con respecto al Desarrollo no verbal, su desempeño también es heterogéneo, denotando mejores recursos en Estructura Espacial, observándose buena comprensión y utilización de las nociones espaciales, ubicándose en una performance general Superior al promedio.

En Viso-percepción logra convertir una matriz mental en un constructo concreto, encontramos que en las tareas de reproducción gráfica de modelos se ubica en el rango Promedio, debido a que todavía se observan fallas en el cierre, la configuración de ángulos y la integración de las figuras. Mismo desempeño obtuvo en Memoria icónica, donde logra reorganizar la información a través de procesos por los cuales: adquiere, registra, almacena, reproduce y consolida la información verbal. Aquí se puede observar que Salomón obtiene un nivel Promedio en la memoria visual. En Ritmo se encuentra que recuerda y reproduce secuencias cortas, presentando dificultades en la reproducción de estructuras rítmicas más extensas.

Por otro lado, en la escala de Psicomotricidad disminuye su rendimiento, dificultándosele andar en equilibrio, saltar en un pie y tocar con el pulgar todos los dedos de la mano, presentando un rendimiento inferior.

Con relación a las Escalas complementarias, Salomón en Fluidez verbal, obtiene un performance Superior, logrando formar frases a partir de una sola o dos palabraestímulo. No obstante, en Atención, su desempeño se ve disminuido logrando un performance Inferior, presentando dificultades para seleccionar una señal sensorial y convertirla en un percepto, además, todavía no cuenta con la capacidad de distribuir la actividad sobre un curso preciso y organizado. 


\subsubsection{Factor Personal}

A. Dibujo de la familia

a. Observación de conducta

Cuando fue evaluado en el área emocional se mostró una alta predisposición para el trabajo, escuchando las indicaciones y obedeciendo. Durante esta evaluación hubo momentos que se observaron movimientos estereotipados con las manos que iban desde sacudidas de ambas manos por periodos de 10 segundos, como colocar los miembros superiores doblados a la altura de los hombros y realizar aleteos por un tiempo de 5 segundos cuando está eufórico o contento. También presenta dificultades en la articulación de algunas palabras con /r/ y una débil prensión digital. Es inquieto, no maneja sus tiempos, ni espacio, es disperso, y se cansa cuando tiene que realizar redacciones o descripciones de figuras.

\section{b. Datos cualitativos}

Identifica al núcleo familiar, conformado por el padre, la madre, su hermana y él. Se sabe por referencia de los padres que ellos están separados, pero todavía el niño no procesa esta separación considerándolos una familia unida. Identifica como autoridad principal y modelo a la figura paterna Reconoce que ambos padres son sus protectores, pero describe a un padre juguetón y una madre amorosa. Tiene una adecuada relación con la hermana sin negar los celos propios entre hermanos.

Se muestra como un niño impulsivo, todavía mentalmente inmaduro, que evidencia necesidad de tranquilidad emocional y felicidad. Se presenta inseguro, con sentimientos de angustia, que comprometen su autoestima.

Existe una tendencia a la compulsión y falta de decisión, presentando continuos titubeos.

B. Inventario de conducta pre escolar- IDC-PRE 
a. Observación de conducta

Se entregó el cuestionario a la tutora para ser llenado

b. Datos cuantitativos

Tabla 5.4

Resultados IDC-PRE

\begin{tabular}{cccc}
\hline \multicolumn{2}{c}{$\begin{array}{c}\text { Control excesivo } \\
99.4\end{array}$} & \multicolumn{2}{c}{ Control insuficiente } \\
\hline Retraimiento social & Ansiedad & Actividad/ & Irritabilidad/ \\
& & impulsividad & hostilidad \\
99.4 & 99 & 99.4 & 87 \\
\hline
\end{tabular}

Figura 5. 3

Perfil IDC-PRE

\section{ICE PRE ESCOLAR}

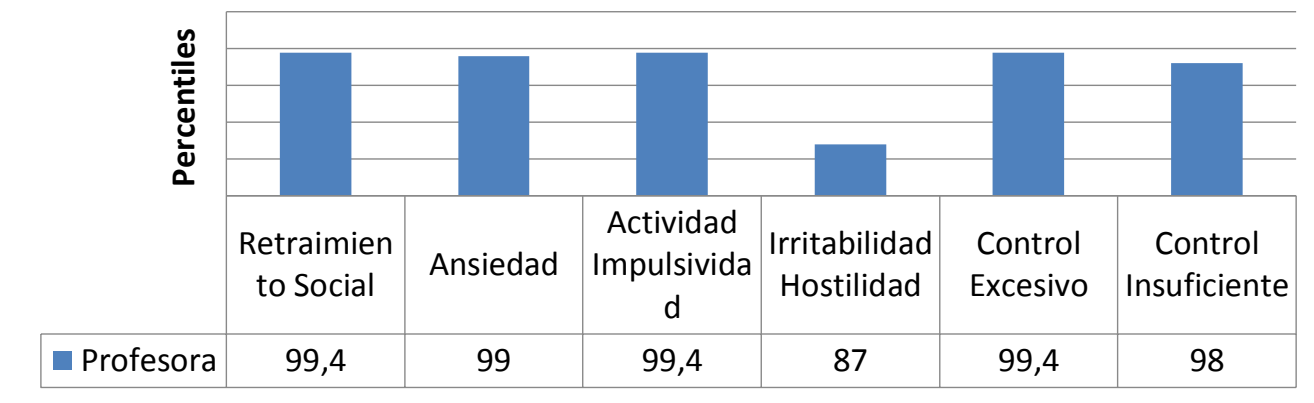

c. Datos cualitativos

Salomón posee puntajes elevados en Retraimiento social. Es decir, existe una propensión a estar solo, ensimismado, retraído, una falta de interés en participar de actividades recreativas o de diversión. 
Por otro lado, presenta también una alto índice de Ansiedad. Lo cual se observa a través de conducta de distracción, impulsividad, hiperactividad, y poco control de sí mismo. Es visto como un niño en constante actividad, impulsividad, distracción, con dificultad para: mantenerse sentado, sostener la atención. Con tendencia a interrumpir, contestar abruptamente, hablar excesivamente y cambiar de actividad sin haber terminado la anterior.

Presenta signo de irritabilidad, hostilidad, tendencia a perder la paciencia y a discutir.

Salomón todavía se encuentra en proceso de regular su conducta en ocasiones reaccionado de manera impulsiva y en otras de forma más controlada. Esto es esperable por la edad.

E. Escala Australiana para el Síndrome de Asperger (EASA) Padres

a. Observación de conducta

Se entregó el cuestionario a los padres para ser llenado

b. Datos cuantitativos

La media obtenida fue de 0.96 , es decir, dentro del nivel normal.

c. Datos cualitativos

Según los resultados de la encuesta a los padres, se obtuvo que Salomón carece de interés en participar de juegos, deportes o actividades competitivas, siendo indiferente a la presión de sus compañeros. Muestra apego hacia objetos como su mantita. Además posee una gran memoria a largo plazo de eventos y hechos, mostrándose sorprendentemente capaz para algunas cosas y sorprendentemente torpe para otras. Por otro lado, presenta tics motores y aleteo y torpeza motora. 
F. Escala Australiana para el Síndrome de Asperger (EASA)-Profesores

a. Observación de conducta

Se entregó el cuestionario a la tutora para ser llenado.

b. Datos cuantitativos

La media obtenida fue de 2.29 , es decir, visiblemente por encima del nivel normal.

c. Datos cualitativos

Según los resultados en la encuesta realizada por los profesores, se sabe que Salomón en el ambiente escolar presenta dificultades al interactuar con sus pares, no logrando entender las reglas del juego, tiene poco interés en participar en juegos, deportes o actividades competitivas, inclusive al ser presionado por sus compañeros. En ocasiones le falta empatía y en otras no y aunque desea ser sociable muchas veces falla en sus relaciones con sus pares. Además carece de un mejor amigo. Al interactuar mantiene menos contacto ocular del esperado. Desvía la mirada. Presenta poca capacidad para entender los niveles de expresión emocional de las otras personas. Al conversar si un tema es confuso para él, no pide aclaraciones. Presenta temor o angustia inusual a ser acariciado.

Por otro lado, posee una buena memoria a largo plazo para eventos y hechos. Es monotemático, y ha desarrollado rituales y rutinas específicas. Muestra pobre coordinación motriz y un modo peculiar de correr. Es torpe. Presenta movimientos involuntarios o tics, una expresión facial y postura notable.

En ocasiones presenta dificultades para realizar tareas diarias a causa de la repetición compulsiva de ciertas acciones o pensamientos. Le cuesta cambiar sus rutinas. En ocasiones muestra apego idiosincrático a objetos. Carece de sentido común y expresa sonidos involuntariamente. 


\subsubsection{Proceso Cognitivo Básico}

A. Conners Comprehensive Behavior Rating Scales-Parents/ Conners Comprehensive Behavior Rating Scales-Teachers

a. Observación de conducta

Se entregó tanto a padres como a la tutora para ser llenado.

b. Datos cuantitativos

Tabla 5.5

Categorías según puntajes

\begin{tabular}{llllll}
\hline PT & PC & Categoría & PT & PC & Categoría \\
\hline $71-$ & $98+$ & Marcadamente atípico & $56-$ & $74-85$ & Levemente atípico \\
98 & & 60 & & \\
$66-$ & $95-98$ & Moderadamente atípico & $0-55$ & $27-73$ & Nivel Promedio-Sin \\
70 & & & & interferencia \\
$61-$ & $86-94$ & Medianamente atípico & & \\
65 & & & & \\
\end{tabular}


Figura 5. 4

Perfil Conners

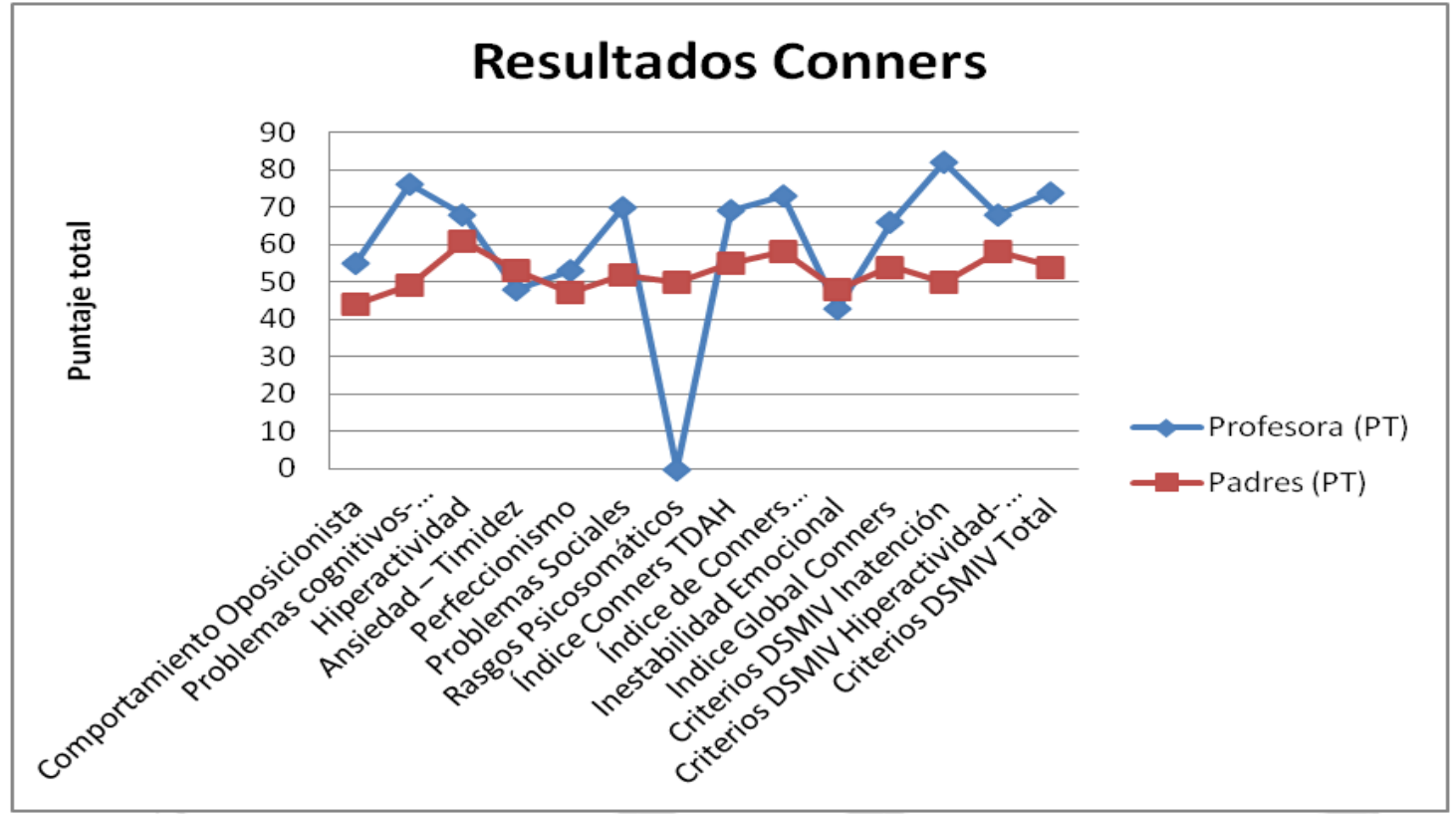

Tabla 5. 6

Resultados Conners

CONDUCTAS

Profesora (PT) Padres (PT)

Comportamiento Oposicionista

55

44

Problemas cognitivos- desatención

76

49

Hiperactividad

68

61

Ansiedad - Timidez

48

53

Perfeccionismo

53

47

Problemas Sociales

70

52

Rasgos Psicosomáticos

Índice Conners TDAH

69

55

Índice de Conners Inquietud/Impulsividad

73

58

Inestabilidad Emocional

43

48

Índice Global Conners

66

54

Criterios DSMIV Inatención

82

50

Criterios DSMIV Hiperactividad-Impulsividad

68

58

Criterios DSMIV Total

74

54 
c. Datos cualitativos

Por las características detalladas por los maestros referentes a la capacidad atencional, sus niveles de inquietud, vimos por conveniente hacer una evaluación de descarte del TDAH - Trastorno por Déficit de Atención con Hiperactividad con pruebas psicológicas idóneas al caso. Es así que usamos dos pruebas obteniendo los siguientes resultados:

- Maestros:

○ Altamente significativo PT 71+

- Problemas cognitivos- desatención

- Criterios DSM IV Inatención

- Criterios del DSM IV Total

- Índice Conners Inquietud/impulsividad

- Moderadamente significativo, PT 66- 70

- Hiperactividad

- Problemas sociales, dificultades para entablar amistades, muchas veces sintiéndose distante de los demás ocasionando los problemas sociales de rechazo.

- Criterios DSMIV de hiperactividad/impulsividad

- Padres:

- Medianamente significativo, PT $61-65$

- Hiperactividad

SEGUNDA FASE: 5 años 8 meses

\subsubsection{Factor Cognitivo Global}


A. Evalúa-0

a. Observación de conducta

En la evaluación de aprendizaje, Salomón se mostró dispuesto para el trabajo, sin embargo, se rendía rápido cuando un ejercicio no le salía bien, sobre todo en los que requerían el uso de motricidad fina.

b. Datos cuantitativos

Tabla 5.7

Resultados factor cognitivo global Evalúa-0

\begin{tabular}{llcl}
\hline ESCALAS & SUBTEST & CENTILES & CATEGORÍA \\
\hline Capacidades & Clasificación & 60 & Medio alto \\
Cognitivas & Series & 20 & Bajo \\
& Números y letras & 70 & Medio alto \\
& Organización & 15 & Bajo \\
& perceptiva & & \\
& Total & 42 & Medio \\
\hline
\end{tabular}


Figura 5. 5

Perfil Evalúa-0

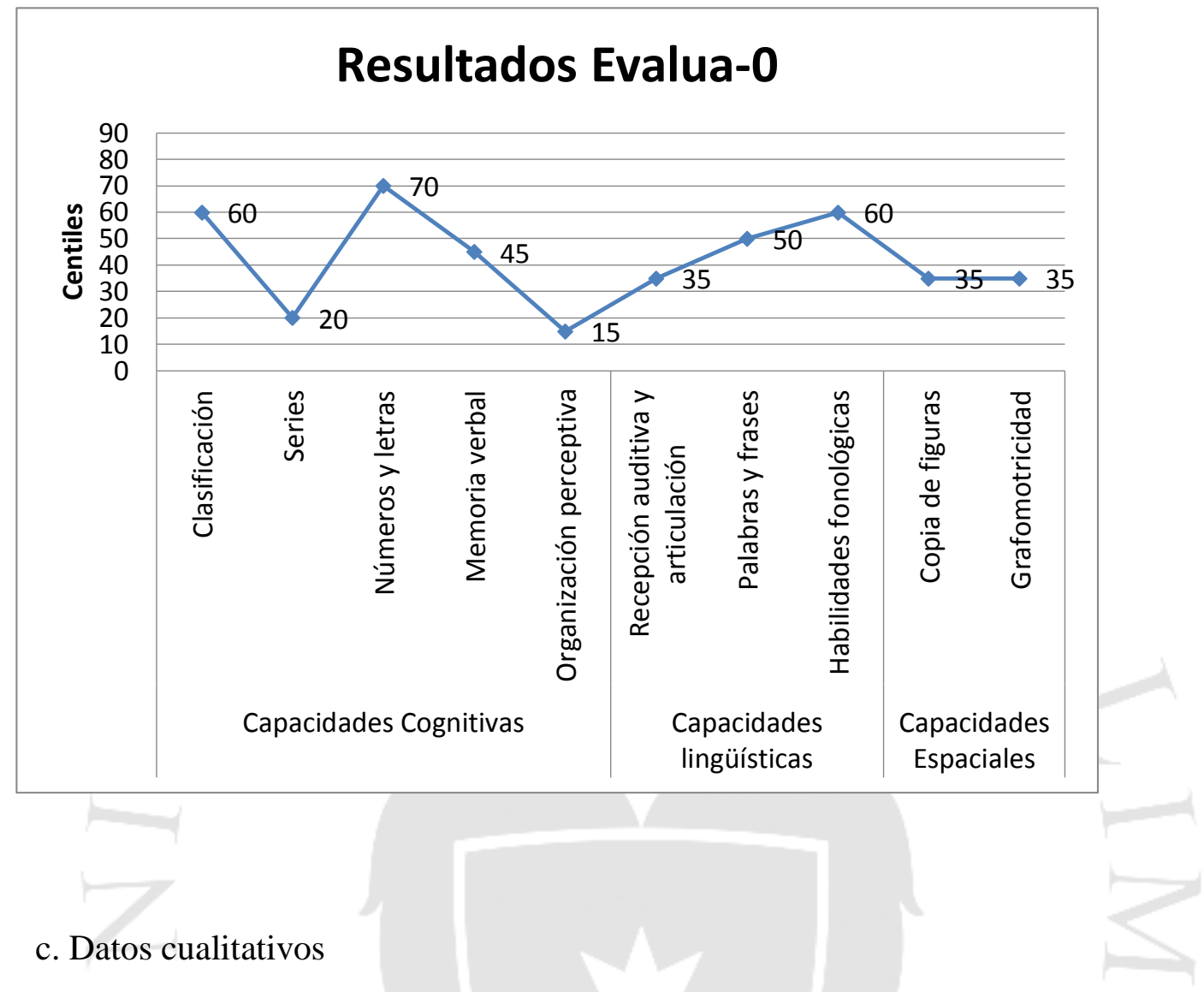

A nivel global, Salomón se ubica en una categoría acorde a su grupo de edad (Promedio). No obstante, se observa gran heterogeneidad dentro de su Desempeño General.

Dentro de sus Capacidades cognitivas, se aprecia un desempeño heterogéneo, con mejores recursos en números y letras y clasificación, ubicándose en la categoría medio alto. En el área de la clasificación logra identificar las figuras geométricas, diferenciando los tamaños y colores. No obstante, todavía presenta dificultades con los estímulos visuales abstractos, costándole eliminar el que no pertenece al grupo. Esto lo ubica en un PC (60). Es capaz de identificar en el subtest de Números y letras todos los números y las letras presentados. Sin embargo, se distrae y no logra encontrar todos los elementos cuando estos se repiten. Esto lo ubica en un PC (70) medio alto.

Disminuye su performance en el subtest de Series, Salomón logra ordenar conjuntos de elementos a partir de sus características específicas. No obstante, se le dificulta diferenciar los tamaños, cantidades grandes, mayor-menor y alturas dentro de 
un grupo. Debido a todos estos aspectos por trabajar se ubica en un PC (20) bajo para su edad.

En la subprueba de Organización perceptiva se le dificulta armar los rompecabezas simples, debido a que no logra ubicar las piezas en el lugar indicado. Esto la ubica en un PC (15) bajo para su edad, derivando en una pobre organización perceptiva.

\subsubsection{Factor Cognitivo Básico}

A. Evalúa-0

a. Datos cuantitativos

Tabla 5.8

Resultados factor cognitivo básico Evalúa-0

\begin{tabular}{llcc}
\hline ESCALAS & SUBTEST & CENTILES & CATEGORÍA \\
\hline Capacidades & Memoria verbal & 45 & Medio \\
Cognitivas & & \\
\hline
\end{tabular}

b. Datos cualitativos

Logró recordar en el subtest de Memoria verbal la mayor parte de una lista de palabras. No obstante, al pedirle que recuerde detalles de una pequeña historia presenta dificultades, costándole traer a la memoria aspectos importantes del cuento. Esto lo ubica en un PC (45) medio para su edad.

\subsubsection{Factor Instrumental}


A. Evalúa-0

a. Datos cuantitativos

Tabla 5.9

Resultados factor instrumental Evalúa-0

\begin{tabular}{llcl}
\hline ESCALAS & SUBTEST & CENTILES & CATEGORÍA \\
\hline Capacidades & Recepción auditiva y & 35 & Medio bajo \\
lingüísticas & articulación & & \\
& Palabras y frases & 50 & Medio \\
& Habilidades & 60 & Medio alto \\
& fonológicas & & \\
& Total & 48 & Medio \\
Capacidades & Copia de figuras & 35 & Medio bajo \\
Espaciales & Grafomotricidad & 35 & Medio bajo \\
& Total & 35 & Medio bajo \\
\hline DESEMPEÑO & & 42 & Medio \\
GENERAL & & & \\
\hline
\end{tabular}

b. Datos cualitativos

Con respecto a sus Capacidades lingüísticas, su desempeño también es heterogéneo, denotando mejores recursos en Habilidades fonológicas, en conciencia silábica logra agrupar las silabas para formar una palabra e identificar el dibujo que le corresponde. Asimismo, es capaz de descomponer las palabras en silabas. En cuanto a conciencia fonética, logra realizar síntesis fonémicas y realizar un análisis fonémico, identificando que, al quitarle un fonema a una palabra se forma otra distinta. Logra hacerlo mejor con ayuda de imágenes visuales sencillas. Esto lo ubica dentro de un PC (60) medio alto para el promedio de edad. 
Similar desempeño se encuentra en palabras o frases, donde logra completar y detectar los errores en las frases. Es capaz de establecer relaciones causales, identificar antónimos y nombrar categorías. Sin embargo, le cuesta construir frases largas con palabras sugeridas y encontrar sinónimos. Esto lo ubica dentro de un PC (50) medio para lo esperado para su edad.

Menor desempeño se encuentra en Recepción auditiva y articulación, presentando una buena articulación. A diferencias de las dificultades encontradas en la discriminación auditiva, costándole identificar las diferencias cuando se le presentan palabras similares. Asimismo, al momento de nombrar imágenes, muchas veces confunde los nombres de estas, cambiándolas por palabras que se encuentran dentro de la categoría pero que no denominan con precisión la imagen presentada. Esto lo ubica en un PC (35) medio bajo para lo esperado para su edad.

En relación a las Capacidades espaciales se aprecia un rendimiento homogéneo en ambas áreas evaluadas. En la Grafomotricidad evidencia mejor dominio frente a línea verticales, como parcialmente angulares, a diferencia de los trazos circulares, obteniendo un PC 35 correspondiente a la categoría medio bajo. En similar desempeño se obtiene en Copia de figuras, presentado habilidades en tamaño y la orientación en figura simple, mientras que en figuras complejas se observa mejor desempeño en ubicación, a diferencia de la forma y tamaño.

\subsubsection{Factor Personal}

A. Evalúa-0

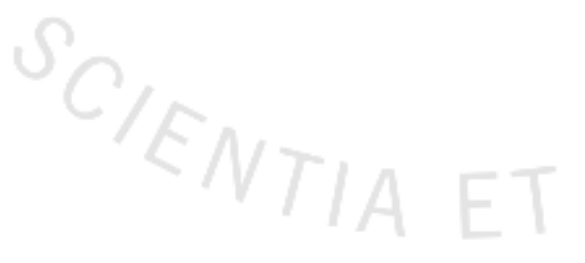

a. Datos cualitativos

Con respecto a Niveles de adaptación, se puede observar Salomón es un niño comunicativo y espontáneo en sus manifestaciones vitales. Actúa libremente sin estar pendiente de las normas sociales. Es imaginativo y con frecuencia tiende a refugiarse en un mundo idealista donde no existen problemas. Asimismo, es inquieto y fácilmente atemorizable. Muestra mucha energía en sus acciones con una alta sensibilidad de 
espíritu. No obstante, le cuesta relacionarse con los otros niños debido a que no logra comprender las reglas de los juegos o le aburren. Su docilidad y sumisión le hacen fácilmente adaptable a las influencias de los demás, ya sea niños o mayores.

Por otro lado, le cuesta organizarse dentro de su espacio, presentando fatiga cuando realiza a actividades que requiere de un periodo prolongado de atención y concentración y perseverancia.

B. Bender

a. Observación de conducta

Durante la evaluación el niño se mostró impulsivo, realizando las copias de forma rápida, observaba una vez y luego copiaba. No obstante, mostro buena disposición para el trabajo.

\section{b. Datos cuantitativos}

Salomón obtuvo 4 errores significativos y 1 no significativo. Además dentro de la parte gráfica presentó un orden confuso, repaso del trazo y segunda tentativa.

c. Datos cualitativos

El nivel de ejecución está por encima de esperado para su edad en las habilidades Visomotoras, ya que alcanza una edad maduracional de 7 años 6 meses a 7 años 11 meses. El evaluado tiene la capacidad desarrollada de integrar las imágenes recibidas a través de la vista y luego poder transformar lo observado en conductas motoras manifestadas a través de un dibujo. Por otro lado, hay indicadores emocionales de ansiedad, impulsividad e incapacidad para manejar el material. 


\subsection{Informe psicológico integral}

\subsubsection{Observación de conducta}

Cuando fue evaluado mostró una alta predisposición para el trabajo, escuchando las indicaciones y obedeciendo. No obstante, se encontraba inquieto, costándole maneja sus tiempos y espacio y esperar tranquilo. Cantaba o hablaba de temas que no tenían relación con la tarea. Además, se rendía rápido cuando un ejercicio no le salía bien, sobre todo en los que requerían el uso de motricidad fina. Durante esta evaluación hubo momentos que se observaron movimientos estereotipados con las manos que iban desde sacudidas de ambas manos por periodos de 10 segundos, como colocar los miembros superiores doblados a la altura de los hombros y realizar aleteos por un tiempo de 5 segundos cuando está eufórico o contento.

También presenta inadecuada articulación de algunas palabras con /r/, inadecuada prensión digital. Es inquieto, no maneja sus tiempos, ni espacio, disperso, y se cansa cuando tiene que realizar redacciones o descripciones de figuras.

Cuando fue evaluado en el área cognitiva, se mostró inquieto, le cuesta esperar, se distrae fácilmente, canta o habla de temas que no tienen relación con la tarea. Presenta un adecuado uso del lenguaje con algunas dificultades en la denominación de palabras, costándole encontrar las palabras adecuadas para expresar lo que desea.

\subsubsection{Interpretación global}

\section{FASE I}

Salomón posee una inteligencia promedio que le permite funcionar de manera sobresaliente en actividades manipulativas, que requieran el uso del razonamiento abstracto. Lo mismo sucede con su capacidad de leguaje comprensivo y expresivo, disminuyendo ligeramente su desempeño en actividades de razonamiento verbal. Sin embargo, al requerir el uso de velocidad de procesamiento, su performance se encuentra por debajo de lo esperado para su edad. 
Es por este desempeño heterogéneo en las distintas áreas que, al realizar tareas que requieren el uso de la inteligencia verbal en combinación con la manipulativa, su rendimiento decae, mostrando dificultades a nivel verbal. Sucede lo mismo en las tareas que combinan velocidad de procesamiento tanto con la habilidad verbal como con la manipulativa, decayendo enormemente su desempeño. Esto se debe a que Salomón presenta dificultades de atención, concentración y coordinación visomotora.

Por otro lado, al utilizar la atención visual y la coordinación viso manual en una misma tarea, Salomón presenta dificultades, disminuyendo su concentración y velocidad de trabajo, le cuesta realizar tareas en la que se requiera una atención sostenida.

Salmón posee fortalezas en las tareas que requieran la capacidad de establecer relaciones lógicas entre los elementos para dar con la respuesta correcta. Estos procesos son parte de la inteligencia fluida y están en la base de la capacidad para el aprendizaje.

Por otro lado, el evaluado muestra debilidades en las actividades que requieren capacidad para adquirir, conservar y recuperar conocimientos referidos a hechos generales, lo que denominamos Inteligencia Cristalizada. Supone, que no logra interiorizar efectivamente la información de su entorno y retenerla para un uso posterior. Asimismo, se le dificultan las tareas que exigen atención sostenida, memoria a corto plazo, percepción visual, flexibilidad cognitiva y motivación. Además de presentar limitaciones en su psicomotricidad.

Dentro de sus Capacidades cognitivas, se aprecia un desempeño heterogéneo, logrando identificar categorías, números y letras. No obstante, todavía presenta dificultades con respecto a los estímulos visuales abstractos, costándole eliminar el que no pertenece al grupo. Disminuye su performance cuando requiere del uso de la seriación. Salomón logra ordenar conjuntos de elementos a partir de sus características específicas. No obstante, se le dificulta diferenciar los tamaños, cantidades grandes, mayor-menor y alturas dentro de un grupo.

A nivel emocional Salomón es un niño inquieto e impulsivo. Evidencia necesidad de tranquilidad emocional, equilibrio, armonía y orden. Presenta indicadores de inseguridad, además de sentimientos de angustia, que comprometen su autoestima. Asimismo, existe una tendencia a la compulsión y falta de decisión, presentando continuos titubeos. 
Por otro lado, presenta también una alto índice de ansiedad. Lo cual se observa a través de conducta de distracción, hiperactividad, y poco control de sí mismo.

A nivel conductual es un niño en constante actividad, con dificultad para mantenerse sentado y sostener la atención. Muestra tendencia a interrumpir, contestar abruptamente, hablar excesivamente y cambiar de actividad sin haber terminado la anterior. Además, presenta signos de irritabilidad, tendencia a perder la paciencia y a discutir. Salomón todavía se encuentra en proceso de regular su conducta, en ocasiones reaccionado de manera impulsiva y en otras de forma más controlada. Tiende a agotarse fácilmente y ante las dificultades perder la confianza en sí mismo.

Con respecto a sus habilidades sociales, le cuesta relacionarse con los otros niños debido a que no logra comprender las reglas de los juegos o le aburren. Tiene poco interés en participar en juegos, deportes o actividades competitivas, inclusive al ser presionado por sus compañeros. Su docilidad y sumisión le hacen fácilmente adaptable a las influencias de los demás, ya sea niños o mayores. Existe una propensión a estar solo, ensimismado, retraído, una falta de interés en participar de actividades recreativas o de diversión.

En ocasiones le falta empatía y aunque desea ser sociable muchas veces falla en sus relaciones con sus pares. Además carece de un mejor amigo. Al interactuar mantiene menos contacto ocular del esperado. Desvía la mirada. Presenta poca capacidad para entender los niveles de expresión emocional de las otras personas.

A nivel familiar, identifica al núcleo familiar, conformado por el padre, la madre, su hermana y él. No obstante, todavía no procesa la separación de sus padres, considerándolos una familia unida. Identifica como autoridad principal y modelo seguir a la figura paterna. Reconoce que ambos padres son sus protectores, pero describe a un padre juguetón y una madre amorosa. Tiene una buena relación con la hermana sin negar los celos propios entre hermanos. Se siente aceptado e incluido dentro de la dinámica familiar. No obstante, busca ser el centro de atención dentro de la familia, buscando la aceptación y el afecto de los demás miembros.

Muestra pobre coordinación motriz y un modo peculiar de correr. Tiene movimientos torpes motoramente. 


\section{FASE II}

Con respecto a sus Capacidades lingüísticas, su desempeño también es heterogéneo, denotando mejor performance en actividades que requieran del uso de sus habilidades fonológicas, es decir en conciencia silábica y conciencia fonética. Similar desempeño se encuentra en actividades donde debe establecer relaciones causales, identificar antónimos y nombrar categorías. Sin embargo, le cuesta construir frases largas con palabras sugeridas y encontrar sinónimos.

Por otro lado, presenta una buena articulación. No obstante, muestra dificultades en la discriminación auditiva, costándole identificar las diferencias cuando se le presentan palabras similares. Asimismo, al momento de nombrar imágenes, muchas veces confunde los nombres de estas, cambiándolas por palabras que se encuentran dentro de la categoría pero que no denominan con precisión la imagen presentada.

En relación a las capacidades espaciales, se aprecian dificultades en su grafomotricidad, un mejor dominio frente a líneas verticales, como parcialmente angulares, a diferencia de los trazos circulares. En copia de figuras, presenta habilidades en tamaño y la orientación en figura simple, mientras que en figuras complejas se observa mejor desempeño en ubicación, a diferencia de la forma y tamaño.

En lo referente a su atención, Salomón se distrae fácilmente y no logra cumplir adecuadamente con las tareas propuestas. Existe una tendencia a la dispersión y falta de concentración en tareas escolares. Además, presenta una defectuosa distribución de tiempo para realizar sus actividades. Le cuesta organizarse dentro de su espacio, presentando fatiga cuando realiza a actividades que requiere de un periodo prolongado de atención y concentración y perseverancia.

A nivel de personalidad Salomón es un niño comunicativo y espontáneo en sus manifestaciones vitales. Muestra mucha energía en sus acciones con una alta sensibilidad de espíritu. Actúa libremente sin estar pendiente de las normas sociales. Es imaginativo y con frecuencia tiende a refugiarse en un mundo idealista donde no existen problemas. Muestra interés por integrarse al grupo y agradar a los demás, estando pendiente su entorno. Sin embargo, todavía le cuesta esperar su turno o respetar el espacio del otro, siendo en ocasiones rechazado por sus pares. 
Por otro lado, en lo que respecta a su memoria, posee una buena memoria icónica y memoria a largo plazo para eventos y hechos. Sin embargo, su memoria auditiva es menos precisa, costándole recordar detalles importantes de relatos extensos.

A nivel de percepción, posee una pobre organización perceptiva y una limitada velocidad de procesamiento.

\subsubsection{Presunción diagnóstica}

Salomón muestra indicadores tempranos del TDAH de tipo combinado con hiperactividad, impulsividad e inatención asociado a dificultades en las habilidades sociales, a la velocidad de procesamiento y a la psicomotricidad. Impactando en su desenvolvimiento social, escolar y emocional, derivando en una baja tolerancia a la frustración.

\subsubsection{Pronóstico}

Debido a que se realizó un diagnóstico temprano, derivando en un tratamiento e intervención multidisciplinaria, esto contribuye a un pronóstico más favorable. Además, según investigaciones de Miranda y colaboradores (2002), los niños como Salomón, que reúnen las siguientes características; no presentan problemas de conducta, tienen un coeficiente intelectual promedio, viven en un hogar con padres preocupados y cuentan con profesores preparados; tienen mayores posibilidades de obtener beneficios de la terapia y una mejor respuesta al tratamiento. Asimismo, al orientar a los profesores en técnicas cognitivas y conductuales, estos podrán optimizar la instrucción y manejar el comportamiento de Salomón en el aula. Si Salomón continúa con sus terapias de atención concentración, psicomotricidad y habilidades sociales mejorará en su desempeño ante las exigencias académicas y sociales.

Con respecto a sus habilidades, estarán más enfocadas a nivel de lenguaje por lo que el aprendizaje de la lectura será un hábito sencillo para él y el razonamiento abstracto. 
A nivel de velocidad de procesamiento presenta dificultades que impactan en la precisión y la velocidad de la ejecución de sus tareas. Las dificultades psicomotrices reflejan dificultades en la escritura relacionado con la grafía.

En relación a sus habilidades sociales se hace necesario un trabajo sostenido para desarrollar una mayor empatía y juicio social, lo que lo ayudará a relacionarse mejor con sus compañeros. Además la terapia de atención concentración le permitirá trabajar en su autocontrol, esperar turnos y comprender mejor las reglas del juego. Además, según estudios, a medida que vaya madurando sus niveles de hiperactividad y baja tolerancia disminuirán e ira adaptándose mejor a las demandas del medio.

\subsubsection{Recomendaciones}

Niño:

- Iniciar Terapia de Rehabilitación multidisciplinaria con énfasis en las áreas afectadas: Velocidad de procesamiento, impulsividad, atención, habilidades sociales y psicomotricidad.

Aplicar estrategias cognitivo conductuales para desarrollar su autocontrol.

- Trabajar estrategias metacognitivas para ayudarlo a reflexionar sobre su conducta y las consecuencias de ésta.

- Desarrollar estrategias de habilidades sociales fomentando la asistencia a actividades extracurriculares donde pueda relacionarse con otros niños.

- Realizar una reevaluación neurológica para determinar si el TDAH coexiste con otros trastornos.

Entorno:

- Colegio

- Entrenamiento de los docentes en intervención en el TDAH en el aula

- Realizar un seguimiento en equipo multidisciplinario periódicamente para registrar la evolución del caso. 
- Conocer el perfil individual de fortalezas y debilidades del niño para fomentar la autonomía y el autocontrol en el niño.

- Aplicar estrategias de autocontrol en el aula y en el recreo como:

- Utilizar pictogramas y cuadros conductuales para ayudarlo a recordar las reglas.

- Brindar instrucciones sencillas, asegurándose que repita la indicación para confirmar su comprensión.

- Sentarlo en primera fila.

- Alejarlo de las ventanas para evitar distractores

- Establecer contacto visual para asegurar que está atendiendo.

- Casa

- Conocer sobre las características del diagnóstico de TDAH.

○ Participar en equipo en el seguimiento del trabajo interdisciplinario.

○ Conocer el perfil individual de fortalezas y debilidades de su hijo.

- Fomentar estrategias de autocontrol, resolución de problemas y autocontrol que impacten en su autonomía.

- Establecer pautas claras de conducta y reforzar el cumplimiento de estas.

- Instaurar rutinas en casa para desarrollar autocontrol y mejorar su atención.

- Garantizar un compromiso familiar coadyuve al mejoramiento de su autocontrol.

Tarea

- Contar con un espacio libre de distractores.

- Graduar el nivel de dificultad de las tareas.

- Contar con un planificador para determinar las tareas inmediatas y mediatas.

- Incluir el uso de post-it y recordatorios visuales para ayudarlo a recordar el cumplimiento de actividades. 


\subsubsection{Plan de intervención}

Factores a trabajar:

- Factor personal: tolerancia a la frustración e impulsividad

- Factor cognitivo básico: atención-concentración, velocidad de procesamiento

Objetivo general: Brindarle estrategias para manejar sus dificultades emocionales y atencionales

Objetivo específico: Identificarse con el TDAH

Tabla 5. 10

Sesión 1: Aprender sobre el TDAH

\begin{tabular}{|c|c|c|c|c|c|}
\hline & Actividad & Descripción & Objetivo & Materiales & Tiempo \\
\hline 1 & $\begin{array}{l}\text { Juego de } \\
\text { entrada }\end{array}$ & $\begin{array}{l}\text { Se realiza el saludo y se } \\
\text { le brinda distintas } \\
\text { opciones de juegos de } \\
\text { mesa para que elija. }\end{array}$ & $\begin{array}{l}\text { Fortalecer el } \\
\text { vínculo con el } \\
\text { niño y que este } \\
\text { logre liberar la } \\
\text { ansiedad y } \\
\text { tensión } \\
\text { acumulada. }\end{array}$ & $\begin{array}{l}\text { Diversos } \\
\text { juegos de } \\
\text { mesa: } \\
\text { "Uno", } \\
\text { "Jenga", } \\
\text { "Guacamole } \\
\text { ", } \\
\text { "Pictureca", } \\
\text { "Cranium", } \\
\text { etc. }\end{array}$ & $10 \mathrm{~min}$. \\
\hline 2 & $\begin{array}{l}\text { Conversar } \\
\text { sobre su } \\
\text { semana }\end{array}$ & $\begin{array}{l}\text { Se le pregunta qué tal le } \\
\text { fue en su semana y se } \\
\text { conversa y trata de } \\
\text { encontrar soluciones } \\
\text { juntos, si es que ocurrió } \\
\text { algún incidente. Se } \\
\text { dibuja la situación y las } \\
\text { posibles opciones para } \\
\text { lograr un mejor } \\
\text { entendimiento. }\end{array}$ & $\begin{array}{l}\text { Ayudarlo a } \\
\text { buscar } \\
\text { soluciones } \\
\text { para } \\
\text { situaciones de } \\
\text { la vida diaria. }\end{array}$ & $\begin{array}{l}\text { Hojas bond } \\
\text { Lápiz } \\
\text { Colores } \\
\text { Plumones }\end{array}$ & $7 \mathrm{~min}$. \\
\hline 3 & $\begin{array}{l}\text { Video de } \\
\text { Pablito (1) }\end{array}$ & $\begin{array}{l}\text { Se le muestra un video } \\
\text { de un niño con TDAH }\end{array}$ & $\begin{array}{l}\text { Aprender } \\
\text { sobre el TDAH }\end{array}$ & $\begin{array}{l}\text { Tablet } \\
\text { Internet }\end{array}$ & $3 \mathrm{~min}$ \\
\hline
\end{tabular}




\begin{tabular}{|c|c|c|c|c|c|}
\hline 4 & $\begin{array}{l}\text { Conversar } \\
\text { sobre el video }\end{array}$ & $\begin{array}{l}\text { Se conversa sobre el } \\
\text { video, se le pregunta } \\
\text { cuál era el problema del } \\
\text { niño y si él se parece en } \\
\text { algo al niño del video, } \\
\text { cómo solucionó su } \\
\text { problema el niño. }\end{array}$ & $\begin{array}{l}\text { Identificar } \\
\text { algunas } \\
\text { características } \\
\text { del TDAH en } \\
\text { él y qué trucos } \\
\text { lo pueden } \\
\text { ayudar. }\end{array}$ & Ninguno & $10 \mathrm{~min}$ \\
\hline 5 & $\begin{array}{l}\text { Juego de } \\
\text { atención }\end{array}$ & $\begin{array}{l}\text { Se le presenta el juego } \\
\text { de "memoria", donde } \\
\text { debe encontrar los pares } \\
\text { de imágenes iguales, } \\
\text { volteando las tarjetas } \\
\text { por turnos. }\end{array}$ & $\begin{array}{l}\text { Reforzar su } \\
\text { atención }\end{array}$ & $\begin{array}{l}\text { Juego de } \\
\text { "memoria" }\end{array}$ & $10 \mathrm{~min}$ \\
\hline 6 & $\begin{array}{l}\text { Cómo } \\
\text { sintió }\end{array}$ & $\begin{array}{l}\text { Se le explica que } \\
\text { existen diversas } \\
\text { emociones que } \\
\text { sentimos cuando nos } \\
\text { suceden cosas, las } \\
\text { principales son: } \\
\text { felicidad, tristeza, } \\
\text { miedo y molestia. Se le } \\
\text { dice que dibuje cómo se } \\
\text { sitió al jugar "memoria" } \\
\text { cuando no encontraba } \\
\text { los pares de imágenes. }\end{array}$ & $\begin{array}{l}\text { Reconocer e } \\
\text { identificar las } \\
\text { emociones } \\
\text { básicas }\end{array}$ & $\begin{array}{l}\text { Hoja bond } \\
\text { Colores } \\
\text { Lápiz }\end{array}$ & $5 \mathrm{~min}$. \\
\hline
\end{tabular}

Tabla 5. 11

Sesión 2: Ayudarlo a identificar el TDAH en él

\begin{tabular}{|c|c|c|c|c|c|}
\hline & Actividad & Descripción & Objetivo & Materiales & Tiempo \\
\hline 1 & $\begin{array}{l}\text { Juego de } \\
\text { entrada }\end{array}$ & $\begin{array}{l}\text { Se realiza el saludo y se } \\
\text { le brinda distintas } \\
\text { opciones de juegos de } \\
\text { mesa para que elija. }\end{array}$ & $\begin{array}{l}\text { Fortalecer el } \\
\text { vínculo con el } \\
\text { niño y que este } \\
\text { logre liberar la } \\
\text { ansiedad y } \\
\text { tensión } \\
\text { acumulada. }\end{array}$ & $\begin{array}{l}\text { Diversos } \\
\text { juegos de } \\
\text { mesa: } \\
\text { "Uno", } \\
\text { "Jenga", } \\
\text { "Guacamole } \\
\text { ", } \\
\text { "Pictureca", } \\
\text { "Cranium", } \\
\text { etc. }\end{array}$ & $10 \mathrm{~min}$. \\
\hline
\end{tabular}




\begin{tabular}{|c|c|c|c|c|c|}
\hline 2 & $\begin{array}{l}\text { Conversar } \\
\text { sobre su } \\
\text { semana }\end{array}$ & $\begin{array}{l}\text { Se le pregunta qué tal le } \\
\text { fue en su semana y se } \\
\text { conversa y trata de } \\
\text { encontrar soluciones } \\
\text { juntos, si es que ocurrió } \\
\text { algún incidente. Se } \\
\text { dibuja la situación y las } \\
\text { posibles opciones para } \\
\text { lograr un mejor } \\
\text { entendimiento. }\end{array}$ & $\begin{array}{l}\text { Ayudarlo a } \\
\text { buscar } \\
\text { soluciones } \\
\text { para } \\
\text { situaciones de } \\
\text { la vida diaria. }\end{array}$ & $\begin{array}{l}\text { Hojas bond } \\
\text { Lápiz } \\
\text { Colores } \\
\text { Plumones }\end{array}$ & $7 \mathrm{~min}$. \\
\hline 3 & $\begin{array}{l}\text { Video de } \\
\text { Pablito (2) }\end{array}$ & $\begin{array}{l}\text { Se le muestra un video } \\
\text { de un niño con TDAH }\end{array}$ & $\begin{array}{l}\text { Aprender } \\
\text { sobre el TDAH }\end{array}$ & $\begin{array}{l}\text { Tablet } \\
\text { Internet }\end{array}$ & $3 \mathrm{~min}$ \\
\hline 4 & $\begin{array}{l}\text { Conversar } \\
\text { sobre el video }\end{array}$ & $\begin{array}{l}\text { Se conversa sobre el } \\
\text { video, se le pregunta } \\
\text { cuál era el problema del } \\
\text { niño y si él se parece en } \\
\text { algo al niño del video, } \\
\text { cómo solucionó su } \\
\text { problema el niño. }\end{array}$ & $\begin{array}{l}\text { Identificar } \\
\text { algunas } \\
\text { características } \\
\text { del TDAH en } \\
\text { él y qué trucos } \\
\text { lo pueden } \\
\text { ayudar. }\end{array}$ & & $10 \mathrm{~min}$ \\
\hline 5 & $\begin{array}{l}\text { Juego de } \\
\text { atención }\end{array}$ & $\begin{array}{l}\text { Se le presenta el juego } \\
\text { de "memoria", donde } \\
\text { debe encontrar los pares } \\
\text { de imágenes iguales, } \\
\text { volteando las tarjetas } \\
\text { por turnos. }\end{array}$ & $\begin{array}{l}\text { Reforzar su } \\
\text { atención }\end{array}$ & $\begin{array}{l}\text { Juego de } \\
\text { "memoria" }\end{array}$ & $10 \mathrm{~min}$ \\
\hline 6 & $\begin{array}{l}\text { Cómo se } \\
\text { sintió }\end{array}$ & $\begin{array}{l}\text { Se le explica que } \\
\text { existen diversas } \\
\text { emociones que } \\
\text { sentimos cuando nos } \\
\text { suceden cosas, las } \\
\text { principales son: } \\
\text { felicidad, tristeza, } \\
\text { miedo y molestia. Se le } \\
\text { dice que dibuje cómo se } \\
\text { sitió al jugar "memoria" } \\
\text { cuando no encontraba } \\
\text { los pares de imágenes. }\end{array}$ & $\begin{array}{l}\text { Reconocer e } \\
\text { identificar las } \\
\text { emociones } \\
\text { básicas }\end{array}$ & $\begin{array}{l}\text { Hoja bond } \\
\text { Colores } \\
\text { Lápiz }\end{array}$ & $5 \mathrm{~min}$. \\
\hline
\end{tabular}

Objetivo específico: Aprender a organizarse solo 
Tabla 5. 12

Sesión 3: Aprender los pasos para realizar una tarea

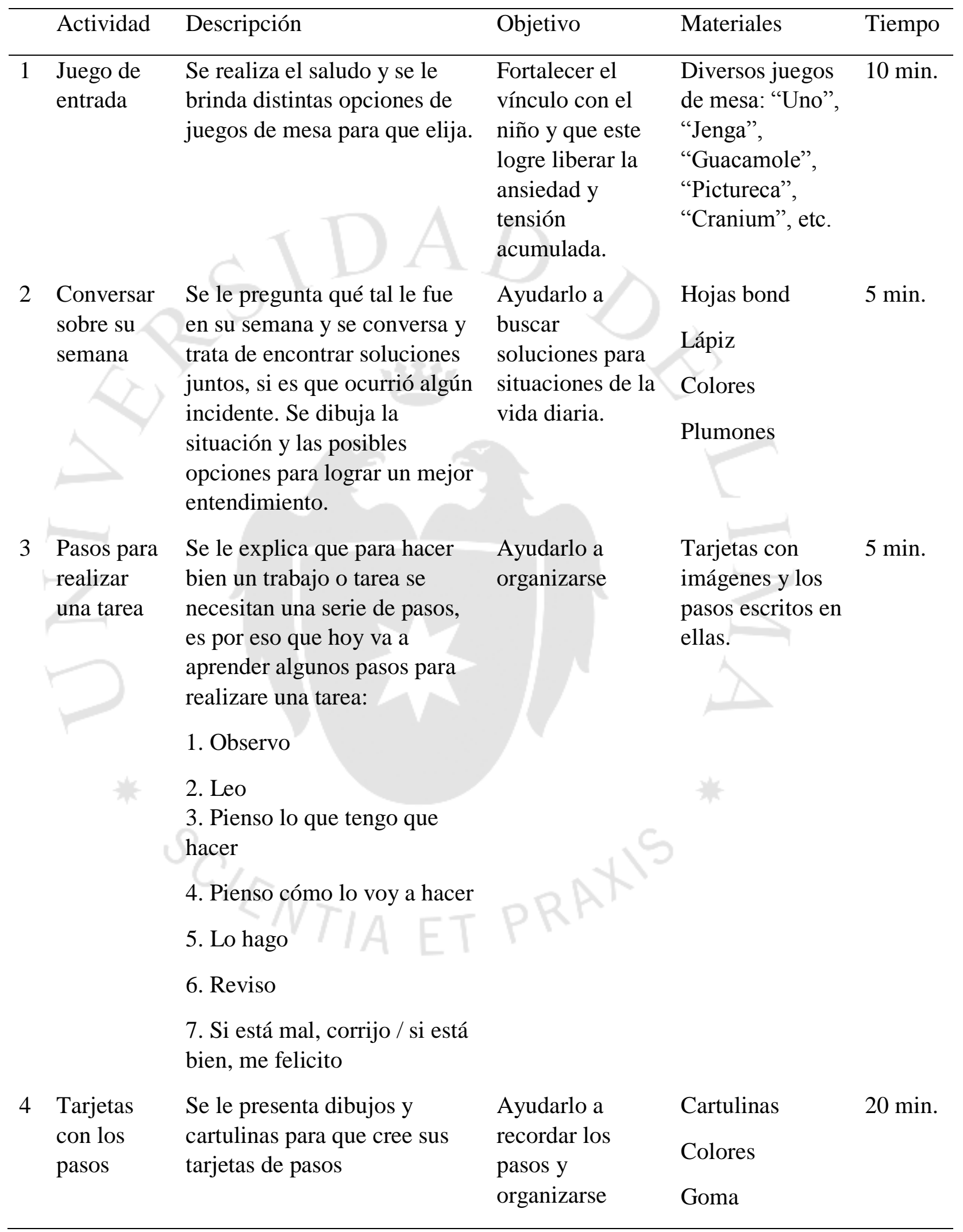


Tijeras

5 Ordenar Se le indica que ordene las Ayudarlo a Tarjetas de $5 \min$ las tarjetas tarjetas de memoria, luego se organizarse pasos revisa y cuando lo haya hecho correctamente se le dice que les ponga número detrás.

Tabla 5. 13

Sesión 4: Recordar y ejecutar los pasos para realizar una tarea

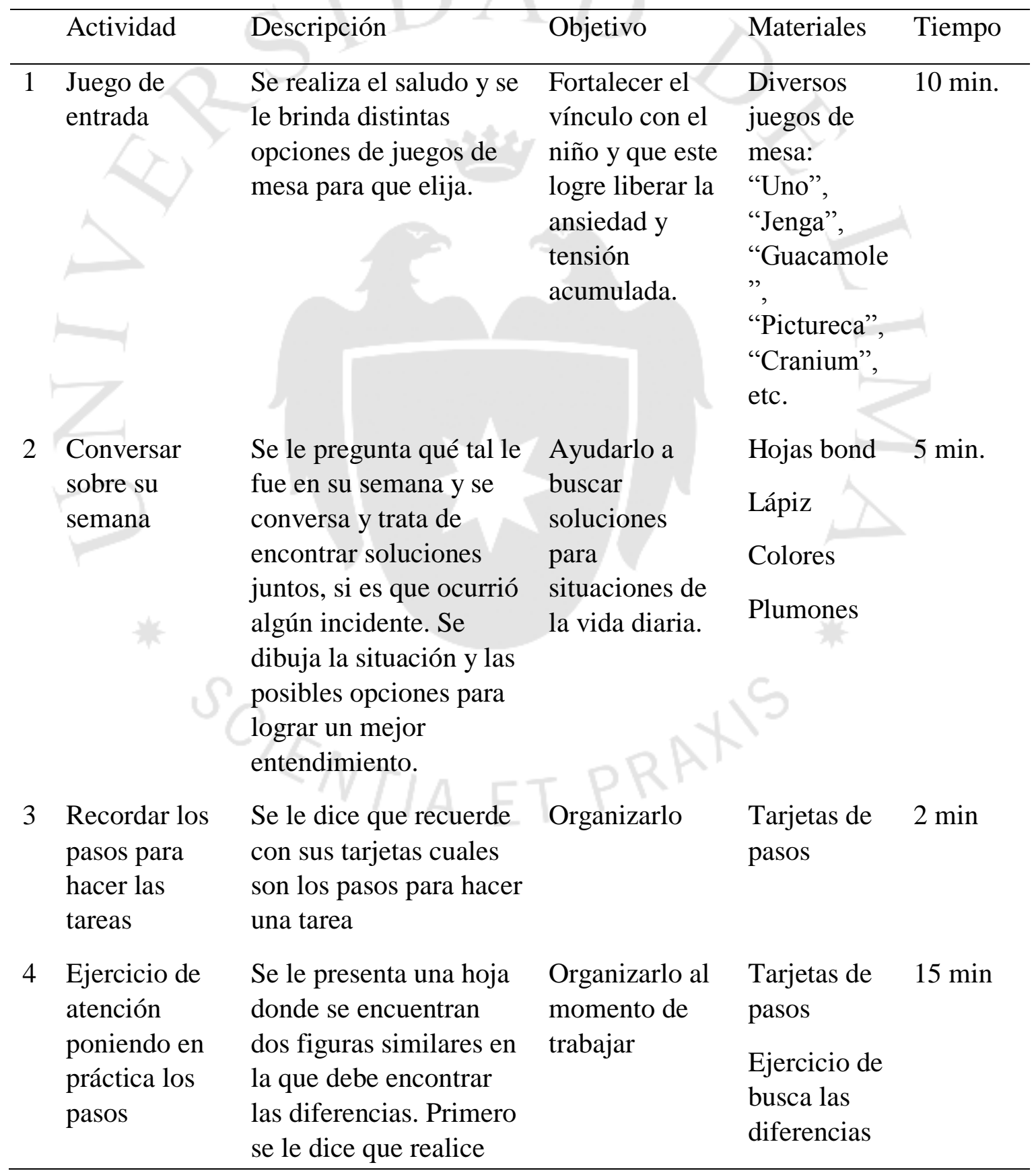




\begin{tabular}{|c|c|c|c|c|c|}
\hline & & $\begin{array}{l}\text { los pasos previos a } \\
\text { realizar una tarea, } \\
\text { utilizando sus tarjetas. }\end{array}$ & & & \\
\hline 5 & $\begin{array}{l}\text { Juego de } \\
\text { atención }\end{array}$ & $\begin{array}{l}\text { Se le presenta el juego } \\
\text { de "blanco y negro", } \\
\text { donde en un tablero } \\
\text { debe ir volteando las } \\
\text { fichas de su color que } \\
\text { estén a los extremos de } \\
\text { las fichas contrarias } \\
\text { para convertirlas a su } \\
\text { color y ganar todas las } \\
\text { que pueda. }\end{array}$ & $\begin{array}{l}\text { Focalizar su } \\
\text { atención }\end{array}$ & $\begin{array}{l}\text { Juego de } \\
\text { "blanco y } \\
\text { negro" }\end{array}$ & $10 \mathrm{~min}$ \\
\hline 6 & $\begin{array}{l}\text { Cómo se } \\
\text { sintió }\end{array}$ & $\begin{array}{l}\text { Se le dice que señale } \\
\text { dentro de una lámina } \\
\text { con caritas cómo se } \\
\text { sitió. }\end{array}$ & $\begin{array}{l}\text { Reconocer e } \\
\text { identificar las } \\
\text { emociones } \\
\text { básicas }\end{array}$ & $\begin{array}{l}\text { Lámina con } \\
\text { caritas }\end{array}$ & $3 \mathrm{~min}$. \\
\hline
\end{tabular}

Objetivo específico: Rehabilitar las funciones ejecutivas

Tabla 5. 14

Sesión 5: Reforzar la selección y ejecución de pasos

\begin{tabular}{|c|c|c|c|c|c|}
\hline & Actividad & Descripción & Objetivo & Materiales & Tiempo \\
\hline 1 & $\begin{array}{l}\text { Juego de } \\
\text { entrada }\end{array}$ & $\begin{array}{l}\text { Se realiza el saludo y se } \\
\text { le brinda distintas } \\
\text { opciones de juegos de } \\
\text { mesa para que elija. }\end{array}$ & $\begin{array}{l}\text { Fortalecer el } \\
\text { vínculo con el } \\
\text { niño y que este } \\
\text { logre liberar la } \\
\text { ansiedad y } \\
\text { tensión } \\
\text { acumulada. }\end{array}$ & $\begin{array}{l}\text { Diversos } \\
\text { juegos de } \\
\text { mesa: } \\
\text { "Uno", } \\
\text { "Jenga", } \\
\text { "Guacamole } \\
\text { ", } \\
\text { "Pictureca", } \\
\text { "Cranium", } \\
\text { etc. }\end{array}$ & $10 \mathrm{~min}$. \\
\hline 2 & $\begin{array}{l}\text { Conversar } \\
\text { sobre su } \\
\text { semana }\end{array}$ & $\begin{array}{l}\text { Se le pregunta qué tal le } \\
\text { fue en su semana y se } \\
\text { conversa y trata de } \\
\text { encontrar soluciones } \\
\text { juntos, si es que ocurrió } \\
\text { algún incidente. Se }\end{array}$ & $\begin{array}{l}\text { Ayudarlo a } \\
\text { buscar } \\
\text { soluciones } \\
\text { para }\end{array}$ & $\begin{array}{l}\text { Hojas bond } \\
\text { Lápiz } \\
\text { Colores } \\
\text { Plumones }\end{array}$ & $5 \mathrm{~min}$. \\
\hline
\end{tabular}




\begin{tabular}{|c|c|c|c|c|c|}
\hline & & $\begin{array}{l}\text { dibuja la situación y las } \\
\text { posibles opciones para } \\
\text { lograr un mejor } \\
\text { entendimiento. }\end{array}$ & $\begin{array}{l}\text { situaciones de } \\
\text { la vida diaria. }\end{array}$ & & \\
\hline 3 & $\begin{array}{l}\text { Selección y } \\
\text { ejecución de } \\
\text { planes } \\
\text { cognitivos }\end{array}$ & $\begin{array}{l}\text { Se dice al niño que se le } \\
\text { va a decir actividades } \\
\text { de la vida diaria para } \\
\text { que me explique qué es } \\
\text { lo que hace para } \\
\text { llevarlas a cabo y cómo } \\
\text { resuelves los problemas } \\
\text { que puedan surgir. Por } \\
\text { ejemplo, ¿qué haces } \\
\text { para preparar un } \\
\text { sándwich mixto?, } \\
\text { ¿Cuáles son los pasos } \\
\text { para lavarte los } \\
\text { dientes?". }\end{array}$ & $\begin{array}{l}\text { Conocimiento } \\
\text { de los pasos } \\
\text { requeridos } \\
\text { para una } \\
\text { actividad } \\
\text { compleja }\end{array}$ & $\begin{array}{l}\text { Una lámina } \\
\text { en la que } \\
\text { aparecen } \\
\text { actividades } \\
\text { de la vida } \\
\text { cotidiana de } \\
\text { diferente } \\
\text { complejidad } \\
\text { Una hoja } \\
\text { bond y lápiz }\end{array}$ & $10 \mathrm{~min}$ \\
\hline 4 & $\begin{array}{l}\text { Situaciones } \\
\text { sociales }\end{array}$ & $\begin{array}{l}\text { Se dice al niño que se le } \\
\text { va a decir una serie de } \\
\text { situaciones y debe } \\
\text { contestar algunas } \\
\text { preguntas con respecto } \\
\text { a ellas. Por ejemplo, } \\
\text { ¿qué deberías hacer si } \\
\text { se te avería el coche en } \\
\text { la autopista? [...] ¿Por } \\
\text { qué crees que la gente } \\
\text { se tapa la boca cuando } \\
\text { estornuda? ¿Qué } \\
\text { sucedería si te pasas un } \\
\text { semáforo en rojo? }\end{array}$ & $\begin{array}{l}\text { Fomentar su } \\
\text { razonamiento } \\
\text { social }\end{array}$ & $\begin{array}{l}\text { Una lámina } \\
\text { en la que } \\
\text { aparecen } \\
\text { diferentes } \\
\text { situaciones } \\
\text { cuya } \\
\text { resolución } \\
\text { implica } \\
\text { diferente } \\
\text { grado de } \\
\text { razonamient } \\
\text { o social. } \\
\text { Ca }\end{array}$ & $10 \mathrm{~min}$ \\
\hline 5 & $\begin{array}{l}\text { Juego de } \\
\text { atención }\end{array}$ & $\begin{array}{l}\text { Se le presenta el juego } \\
\text { de "rompecabezas" } \\
\text { donde debe orientarse } \\
\text { espacialmente y } \\
\text { focalizar su atención } \\
\text { para armar la figura. }\end{array}$ & $\begin{array}{l}\text { Focalizar su } \\
\text { atención y } \\
\text { orientación } \\
\text { espacial }\end{array}$ & $\begin{array}{l}\text { Juego de } \\
\text { "rompecabe } \\
\text { zas" }\end{array}$ & $10 \mathrm{~min}$ \\
\hline 6 & $\begin{array}{l}\text { Cómo se } \\
\text { sintió }\end{array}$ & $\begin{array}{l}\text { Se le dice que señale } \\
\text { dentro de una lámina } \\
\text { con caritas cómo se } \\
\text { sintió al jugar y } \\
\text { explique el porqué. }\end{array}$ & $\begin{array}{l}\text { Reconocer e } \\
\text { identificar las } \\
\text { emociones } \\
\text { básicas }\end{array}$ & $\begin{array}{l}\text { Lámina con } \\
\text { caritas }\end{array}$ & $3 \mathrm{~min}$. \\
\hline
\end{tabular}


Tabla 5. 15

Sesión 6: Reforzar el pensamiento inferencial y la capacidad de categorización

\begin{tabular}{|c|c|c|c|c|c|}
\hline & Actividad & Descripción & Objetivo & Materiales & Tiempo \\
\hline 1 & $\begin{array}{l}\text { Juego de } \\
\text { entrada }\end{array}$ & $\begin{array}{l}\text { Se realiza el saludo y se } \\
\text { le brinda distintas } \\
\text { opciones de juegos de } \\
\text { mesa para que elija. }\end{array}$ & $\begin{array}{l}\text { Fortalecer el } \\
\text { vínculo con el } \\
\text { niño y que este } \\
\text { logre liberar la } \\
\text { ansiedad y } \\
\text { tensión } \\
\text { acumulada. }\end{array}$ & $\begin{array}{l}\text { Diversos } \\
\text { juegos de } \\
\text { mesa: } \\
\text { "Uno", } \\
\text { "Jenga", } \\
\text { "Guacamole } \\
\text { ", } \\
\text { "Pictureca", } \\
\text { "Cranium", } \\
\text { etc. }\end{array}$ & $10 \mathrm{~min}$. \\
\hline 2 & $\begin{array}{l}\text { Conversar } \\
\text { sobre su } \\
\text { semana }\end{array}$ & $\begin{array}{l}\text { Se le pregunta qué tal le } \\
\text { fue en su semana y se } \\
\text { conversa y trata de } \\
\text { encontrar soluciones } \\
\text { juntos, si es que ocurrió } \\
\text { algún incidente. Se } \\
\text { dibuja la situación y las } \\
\text { posibles opciones para } \\
\text { lograr un mejor } \\
\text { entendimiento. }\end{array}$ & $\begin{array}{l}\text { Ayudarlo a } \\
\text { buscar } \\
\text { soluciones } \\
\text { para } \\
\text { situaciones de } \\
\text { la vida diaria. }\end{array}$ & $\begin{array}{l}\text { Hojas bond } \\
\text { Lápiz } \\
\text { Colores } \\
\text { Plumones }\end{array}$ & 5 min. \\
\hline 3 & $\begin{array}{l}\text { Pensamiento } \\
\text { inferencial }\end{array}$ & $\begin{array}{l}\text { Te voy a hacer unas } \\
\text { preguntas que debes } \\
\text { contestar. La pelota se } \\
\text { metió en el hoyo, ¿A } \\
\text { qué deporte jugaba? } \\
\text { Es un día maravilloso } \\
\text { para ir de picnic. ¿Qué } \\
\text { tiempo hace? } \\
\text { Coge cacahuetes con la } \\
\text { trompa. ¿De qué animal } \\
\text { se trata? }\end{array}$ & $\begin{array}{l}\text { Fomentar el } \\
\text { pensamiento } \\
\text { inferencial }\end{array}$ & $\begin{array}{l}\text { Lámina con } \\
\text { preguntas } \\
\text { inferenciale } \\
\text { s de } \\
\text { diferente } \\
\text { complejidad }\end{array}$ & $10 \mathrm{~min}$ \\
\hline
\end{tabular}




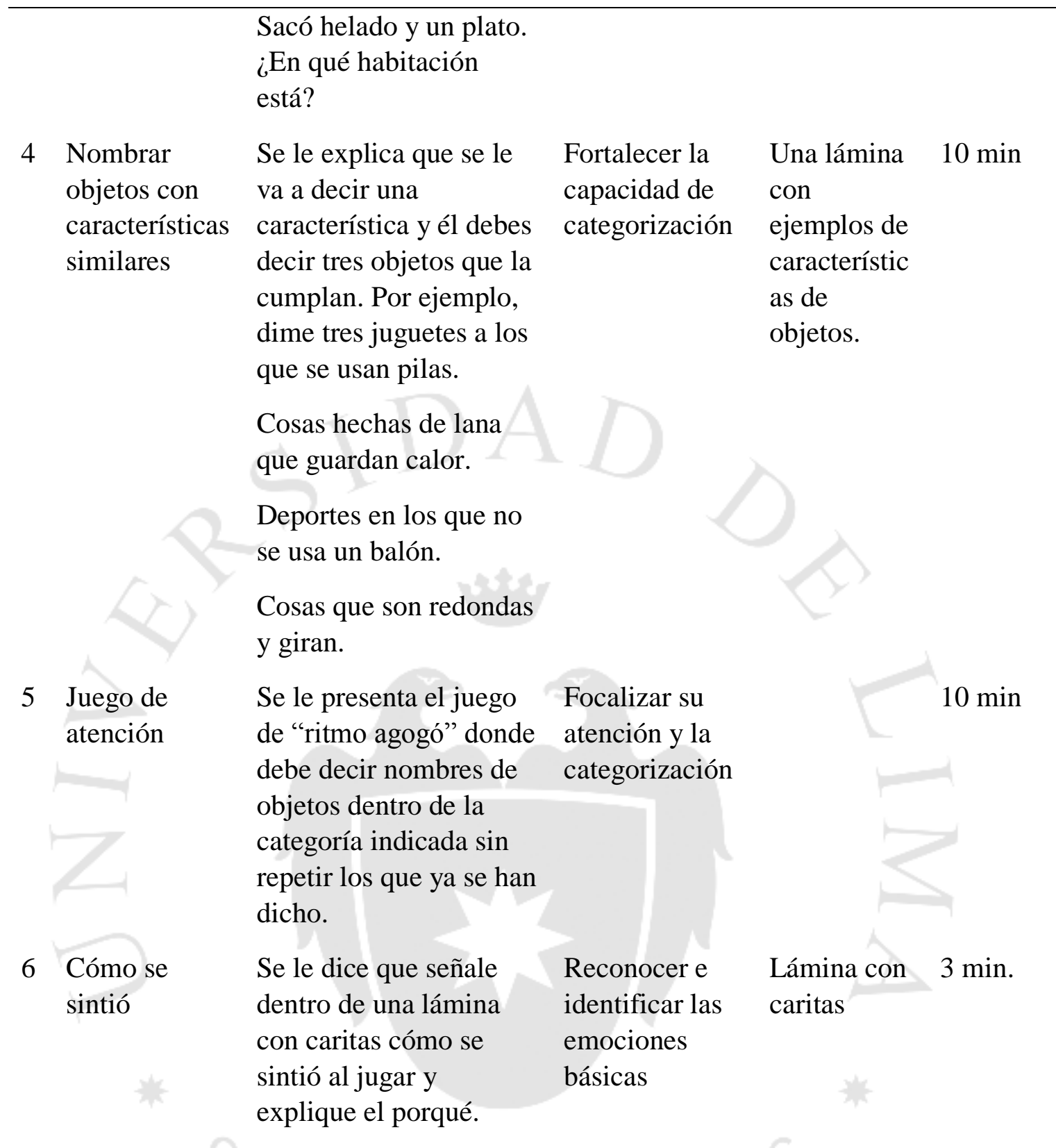

Tabla 5. 16

Sesión 7: Reforzar la solución de problemas inferenciales y manejo de información independiente

\begin{tabular}{|c|c|c|c|c|c|}
\hline & Actividad & Descripción & Objetivo & Materiales & Tiempo \\
\hline 1 & $\begin{array}{l}\text { Juego de } \\
\text { entrada }\end{array}$ & $\begin{array}{l}\text { Se realiza el saludo y se } \\
\text { le brinda distintas }\end{array}$ & $\begin{array}{l}\text { Fortalecer el } \\
\text { vínculo con el } \\
\text { niño y que este } \\
\text { logre liberar la }\end{array}$ & $\begin{array}{l}\text { Diversos } \\
\text { juegos de } \\
\text { mesa: } \\
\text { "Uno", }\end{array}$ & $10 \mathrm{~min}$. \\
\hline
\end{tabular}




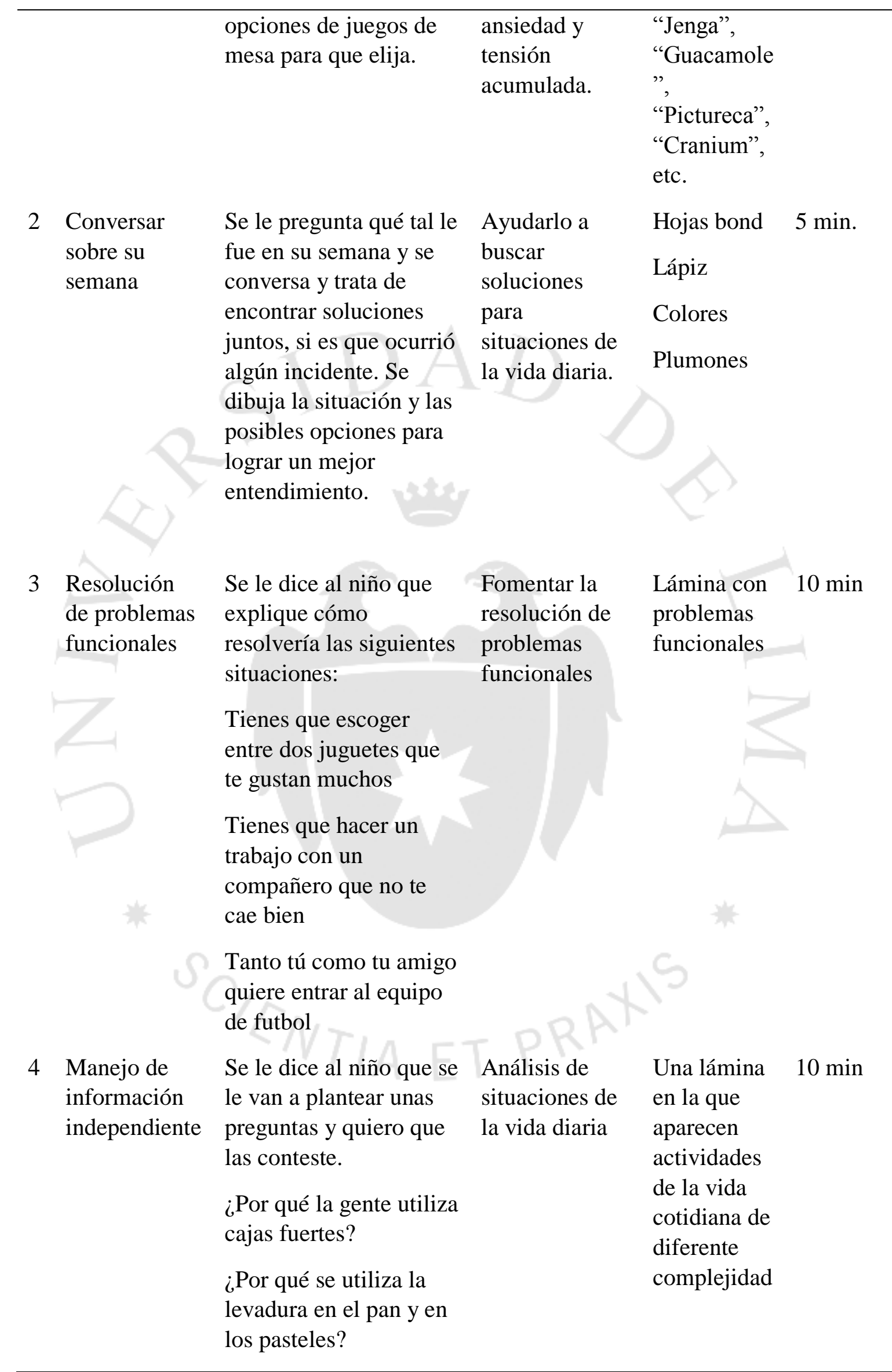




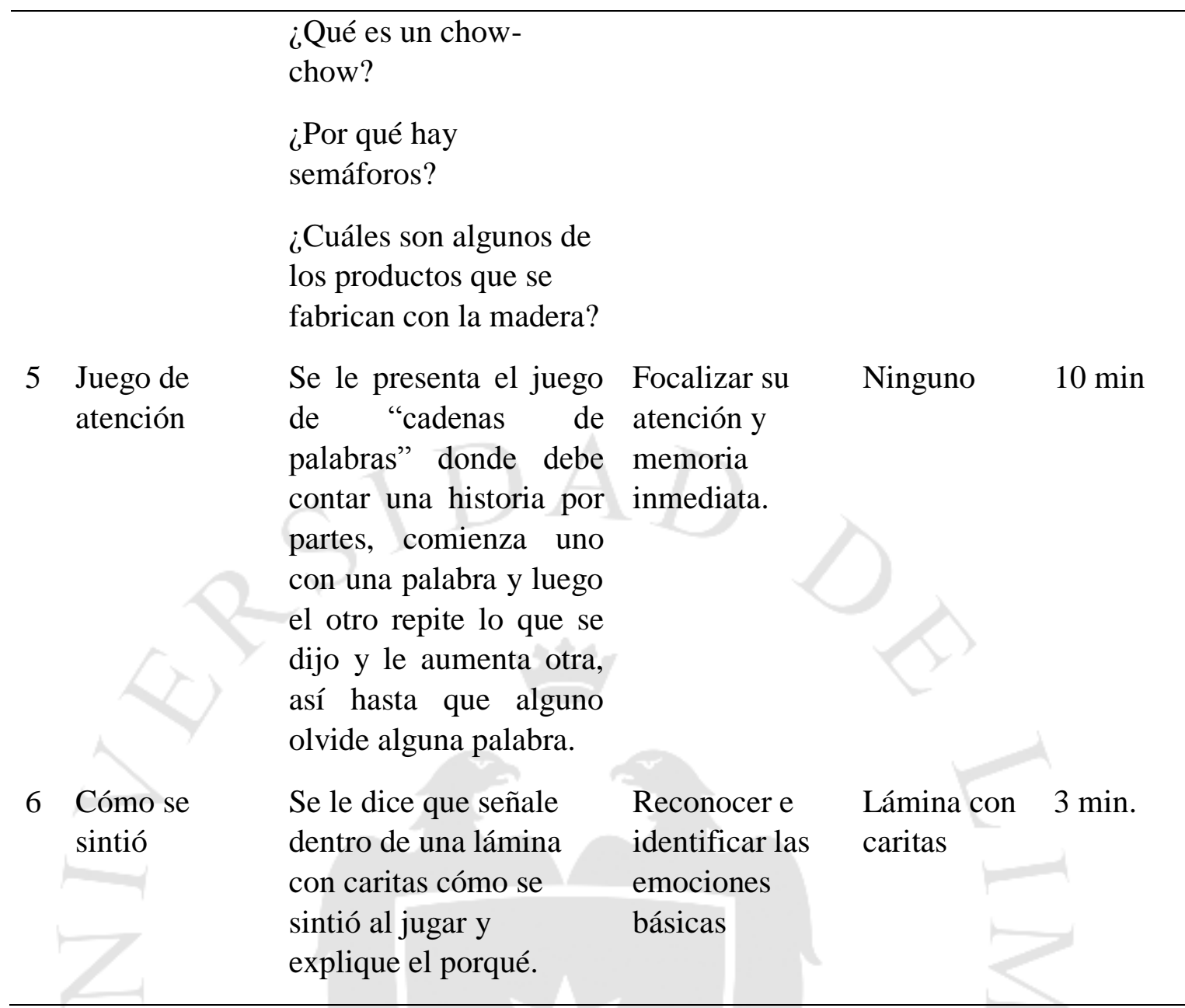

Objetivo específico: Aumentar la flexibilidad cognitiva

Tabla 5. 17

Sesión 8: Trabajar en la flexibilidad cognitiva

\begin{tabular}{|c|c|c|c|c|c|}
\hline & Actividad & Descripción & Objetivo & Materiales & Tiempo \\
\hline 1 & $\begin{array}{l}\text { Juego de } \\
\text { entrada }\end{array}$ & $\begin{array}{l}\text { Se realiza el saludo y se } \\
\text { le brinda distintas } \\
\text { opciones de juegos de } \\
\text { mesa para que elija. }\end{array}$ & $\begin{array}{l}\text { Lograr liberar } \\
\text { la ansiedad y } \\
\text { tensión } \\
\text { acumulada. }\end{array}$ & $\begin{array}{l}\text { Diversos } \\
\text { juegos de } \\
\text { mesa: } \\
\text { "Uno", } \\
\text { "Jenga", } \\
\text { "Guacamole } \\
\text { ", } \\
\text { "Pictureca", }\end{array}$ & $10 \min$. \\
\hline
\end{tabular}




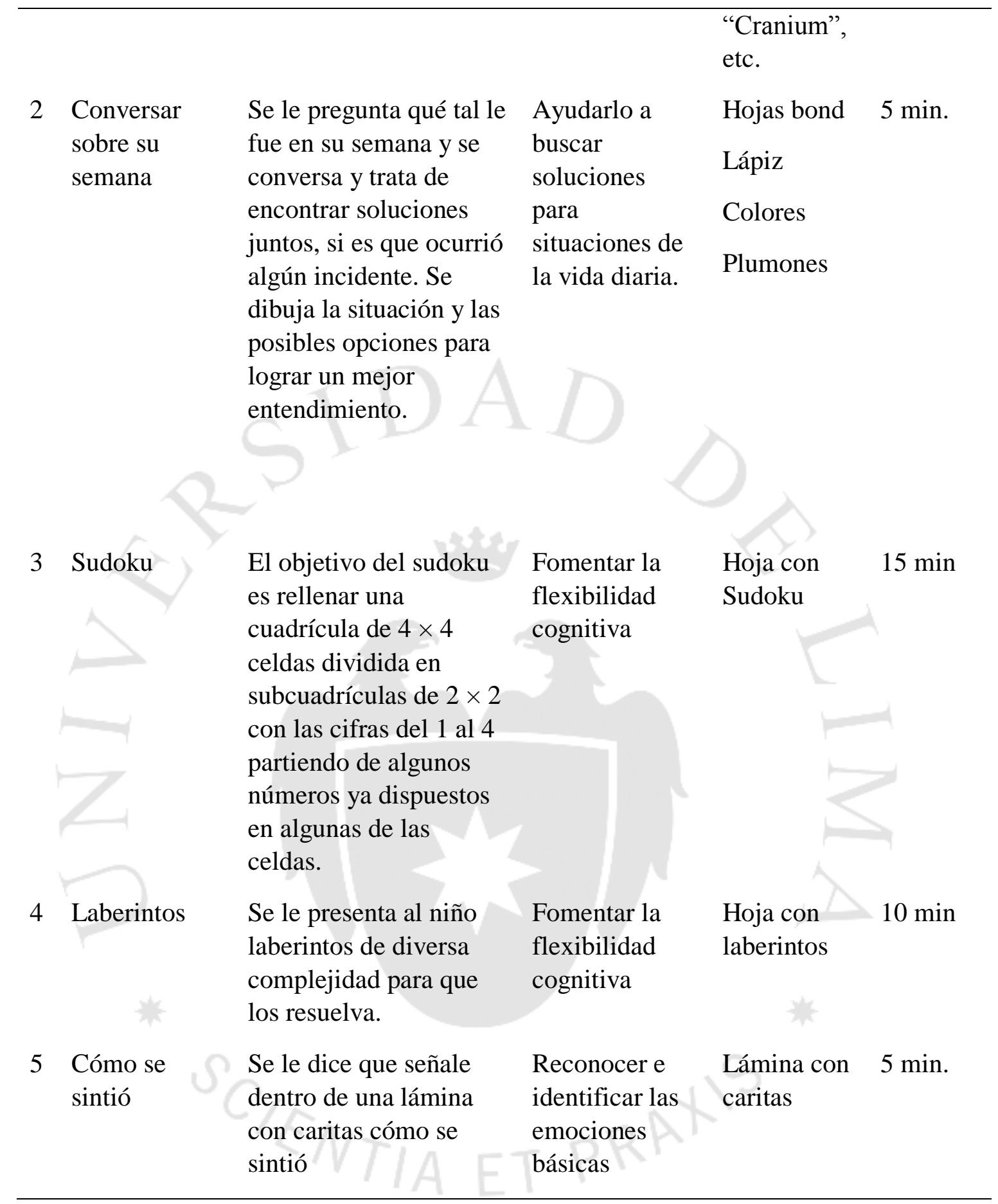

Tabla 5. 18

Sesión 9: Reforzar flexibilidad cognitiva

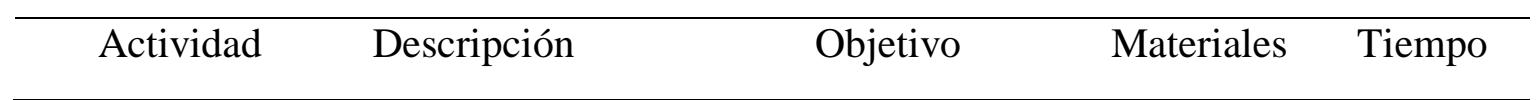




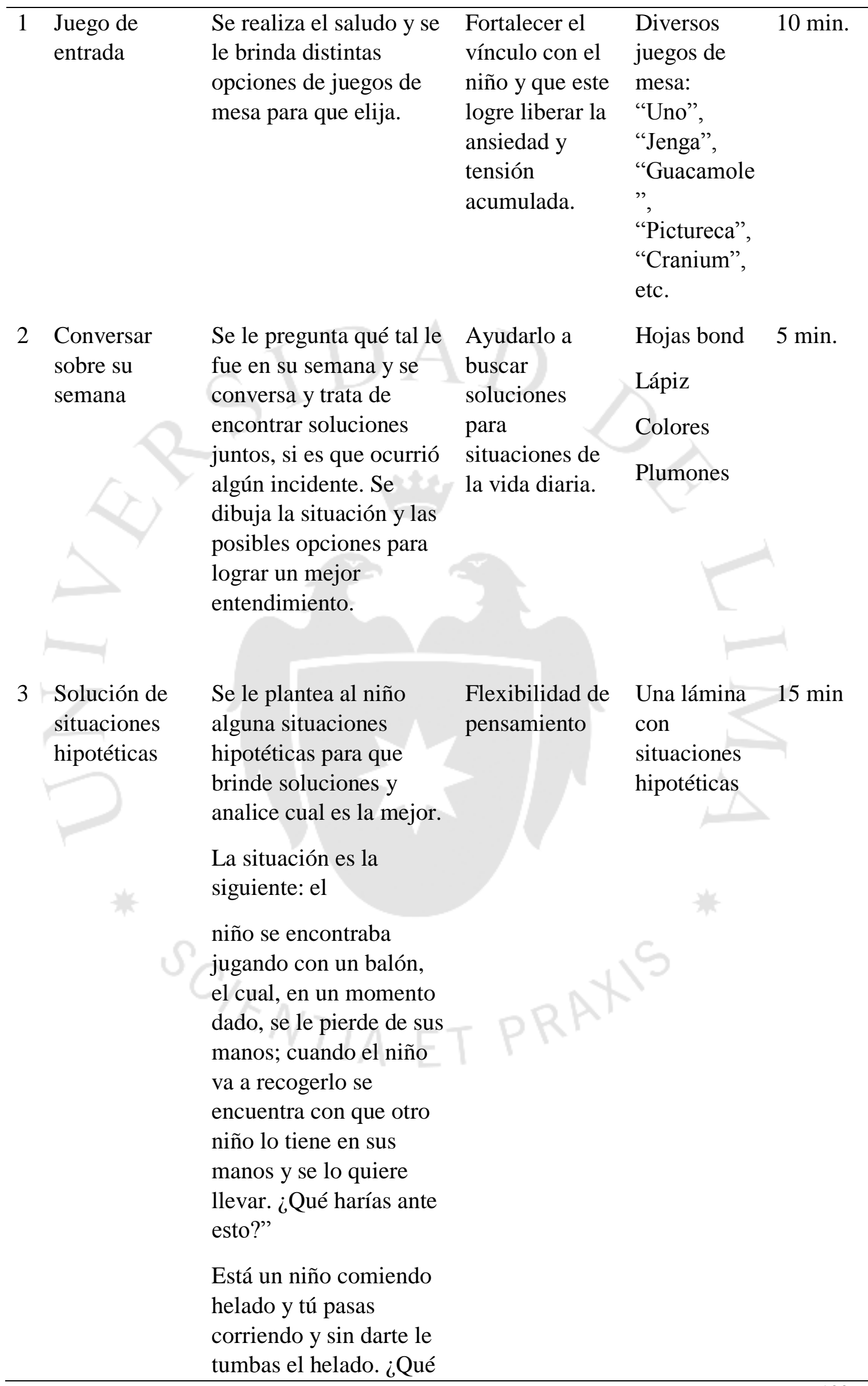




\begin{tabular}{|c|c|c|c|c|c|}
\hline & & $\begin{array}{l}\text { piensas tú, que haría el } \\
\text { otro niño?" }\end{array}$ & & & \\
\hline 4 & $\begin{array}{l}\text { Rompecabeza } \\
\text { s }\end{array}$ & $\begin{array}{l}\text { Se le entrega un } \\
\text { rompecabezas para que } \\
\text { lo arme }\end{array}$ & $\begin{array}{l}\text { Flexibilidad de } \\
\text { pensamiento }\end{array}$ & $\begin{array}{l}\text { Rompecabe } \\
\text { zas }\end{array}$ & $10 \mathrm{~min}$ \\
\hline 5 & $\begin{array}{l}\text { Cómo se } \\
\text { sintió }\end{array}$ & $\begin{array}{l}\text { Se le dice que señale } \\
\text { dentro de una lámina } \\
\text { con caritas cómo se } \\
\text { sintió al jugar y } \\
\text { explique el porqué. }\end{array}$ & $\begin{array}{l}\text { Reconocer e } \\
\text { identificar las } \\
\text { emociones } \\
\text { básicas }\end{array}$ & $\begin{array}{l}\text { Lámina con } \\
\text { caritas }\end{array}$ & $5 \mathrm{~min}$. \\
\hline
\end{tabular}

Tabla 5. 19

Sesión 10: Entrenamiento en solución de problemas

\begin{tabular}{|c|c|c|c|c|c|}
\hline & Actividad & Descripción & Objetivo & Materiales & Tiempo \\
\hline 1 & $\begin{array}{l}\text { Juego de } \\
\text { entrada }\end{array}$ & $\begin{array}{l}\text { Se realiza el saludo y se } \\
\text { le brinda distintas } \\
\text { opciones de juegos de } \\
\text { mesa para que elija. }\end{array}$ & $\begin{array}{l}\text { Fortalecer el } \\
\text { vínculo con el } \\
\text { niño y que este } \\
\text { logre liberar la } \\
\text { ansiedad y } \\
\text { tensión } \\
\text { acumulada. }\end{array}$ & $\begin{array}{l}\text { Diversos } \\
\text { juegos de } \\
\text { mesa: } \\
\text { "Uno", } \\
\text { "Jenga", } \\
\text { "Guacamole } \\
\text { ", } \\
\text { "Pictureca", } \\
\text { "Cranium", } \\
\text { etc. }\end{array}$ & $10 \mathrm{~min}$. \\
\hline 2 & $\begin{array}{l}\text { Conversar } \\
\text { sobre su } \\
\text { semana }\end{array}$ & $\begin{array}{l}\text { Se le pregunta qué tal le } \\
\text { fue en su semana y se } \\
\text { conversa y trata de } \\
\text { encontrar soluciones } \\
\text { juntos, si es que ocurrió } \\
\text { algún incidente. Se } \\
\text { dibuja la situación y las } \\
\text { posibles opciones para } \\
\text { lograr un mejor } \\
\text { entendimiento. }\end{array}$ & $\begin{array}{l}\text { Ayudarlo a } \\
\text { buscar } \\
\text { soluciones } \\
\text { para } \\
\text { situaciones de } \\
\text { la vida diaria. }\end{array}$ & $\begin{array}{l}\text { Hojas bond } \\
\text { Lápiz } \\
\text { Colores } \\
\text { Plumones }\end{array}$ & $5 \mathrm{~min}$. \\
\hline
\end{tabular}




\begin{tabular}{|c|c|c|c|c|c|}
\hline 3 & $\begin{array}{l}\text { Video de un } \\
\text { conflicto }\end{array}$ & $\begin{array}{l}\text { Se le muestra el video } \\
\text { de unos animales } \\
\text { tratando de cruzar un } \\
\text { puente que es solo para } \\
\text { uno. }\end{array}$ & $\begin{array}{l}\text { Búsqueda de } \\
\text { soluciones }\end{array}$ & $\begin{array}{l}\text { Video "el } \\
\text { puente" }\end{array}$ & $5 \mathrm{~min}$ \\
\hline 4 & $\begin{array}{l}\text { Discusión del } \\
\text { video }\end{array}$ & $\begin{array}{l}\text { Se conversa sobre lo } \\
\text { que observó en el } \\
\text { video, cuál era el } \\
\text { conflicto, como lo } \\
\text { resolvieron, que otras } \\
\text { opciones tenían. }\end{array}$ & $\begin{array}{l}\text { Flexibilidad de } \\
\text { pensamiento }\end{array}$ & Ninguno & $10 \mathrm{~min}$ \\
\hline 5 & Dibujo & $\begin{array}{l}\text { Se le pide que dibuje la } \\
\text { parte que más le gustó } \\
\text { del video }\end{array}$ & $\begin{array}{l}\text { Interiorizar la } \\
\text { información }\end{array}$ & $\begin{array}{l}\text { Hoja bond } \\
\text { Lápiz }\end{array}$ & $10 \mathrm{~min}$ \\
\hline 6 & $\begin{array}{l}\text { Cómo se } \\
\text { sintió }\end{array}$ & $\begin{array}{l}\text { Se le dice que señale } \\
\text { dentro de una lámina } \\
\text { con caritas cómo se } \\
\text { sintió al ver el video y } \\
\text { explique el porqué. }\end{array}$ & $\begin{array}{l}\text { Reconocer e } \\
\text { identificar las } \\
\text { emociones } \\
\text { básicas }\end{array}$ & $\begin{array}{l}\text { Lámina con } \\
\text { caritas }\end{array}$ & $5 \mathrm{~min}$. \\
\hline
\end{tabular}

Tabla 5. 20

Sesión 11: Entrenamiento en resolución de problemas

\begin{tabular}{|c|c|c|c|c|c|}
\hline & Actividad & Descripción & Objetivo & Materiales & Tiempo \\
\hline 1 & $\begin{array}{l}\text { Juego de } \\
\text { entrada }\end{array}$ & $\begin{array}{l}\text { Se realiza el saludo y se } \\
\text { le brinda distintas } \\
\text { opciones de juegos de } \\
\text { mesa para que elija. }\end{array}$ & $\begin{array}{l}\text { Fortalecer el } \\
\text { vínculo con el } \\
\text { niño y que este } \\
\text { logre liberar la } \\
\text { ansiedad y } \\
\text { tensión } \\
\text { acumulada. }\end{array}$ & $\begin{array}{l}\text { Diversos } \\
\text { juegos de } \\
\text { mesa: } \\
\text { "Uno", } \\
\text { "Jenga", } \\
\text { "Guacamole } \\
\text { ", } \\
\text { "Pictureca", } \\
\text { "Cranium", } \\
\text { etc. }\end{array}$ & $8 \mathrm{~min}$. \\
\hline
\end{tabular}




\begin{tabular}{|c|c|c|c|c|c|}
\hline 2 & $\begin{array}{l}\text { Conversar } \\
\text { sobre su } \\
\text { semana }\end{array}$ & $\begin{array}{l}\text { Se le pregunta qué tal le } \\
\text { fue en su semana y se } \\
\text { conversa y trata de } \\
\text { encontrar soluciones } \\
\text { juntos, si es que ocurrió } \\
\text { algún incidente. Se } \\
\text { dibuja la situación y las } \\
\text { posibles opciones para } \\
\text { lograr un mejor } \\
\text { entendimiento. }\end{array}$ & $\begin{array}{l}\text { Ayudarlo a } \\
\text { buscar } \\
\text { soluciones } \\
\text { para } \\
\text { situaciones de } \\
\text { la vida diaria. }\end{array}$ & $\begin{array}{l}\text { Hojas bond } \\
\text { Lápiz } \\
\text { Colores } \\
\text { Plumones }\end{array}$ & 5 min. \\
\hline 3 & $\begin{array}{l}\text { Cuento de "la } \\
\text { tortuga y la } \\
\text { liebre" }\end{array}$ & $\begin{array}{l}\text { Se le cuenta el cuento } \\
\text { de "la tortuga y la } \\
\text { liebre" }\end{array}$ & $\begin{array}{l}\text { Búsqueda de } \\
\text { soluciones }\end{array}$ & $\begin{array}{l}\text { Cuento de } \\
\text { "la tortuga y } \\
\text { la liebre" }\end{array}$ & $10 \mathrm{~min}$ \\
\hline 4 & $\begin{array}{l}\text { Discusión del } \\
\text { cuento }\end{array}$ & $\begin{array}{l}\text { Se conversa sobre lo } \\
\text { que recuerda del } \\
\text { cuento, cuál era el } \\
\text { conflicto, como lo } \\
\text { resolvieron, que otras } \\
\text { opciones tenían, cuáles } \\
\text { fueron las } \\
\text { consecuencias para } \\
\text { cada uno de los } \\
\text { personajes. }\end{array}$ & $\begin{array}{l}\text { Flexibilidad de } \\
\text { pensamiento }\end{array}$ & Ninguno & $10 \mathrm{~min}$ \\
\hline 5 & Dibujo & $\begin{array}{l}\text { Se le pide que dibuje la } \\
\text { parte que más le gustó } \\
\text { del cuento }\end{array}$ & $\begin{array}{l}\text { Interiorizar la } \\
\text { información }\end{array}$ & $\begin{array}{l}\text { Hoja bond } \\
\text { Lápiz } \\
\text { Colores }\end{array}$ & $10 \mathrm{~min}$ \\
\hline 6 & $\begin{array}{l}\text { Cómo se } \\
\text { sintió }\end{array}$ & $\begin{array}{l}\text { Se le dice que señale } \\
\text { dentro de una lámina } \\
\text { con caritas cómo se } \\
\text { sintió al escuchar el } \\
\text { cuento y explique el } \\
\text { porqué. }\end{array}$ & $\begin{array}{l}\text { Reconocer e } \\
\text { identificar las } \\
\text { emociones } \\
\text { básicas }\end{array}$ & $\begin{array}{l}\text { Lámina con } \\
\text { caritas }\end{array}$ & $3 \mathrm{~min}$. \\
\hline
\end{tabular}


Tabla 5. 21

Sesión 12: Reforzar la flexibilidad cognitiva

\begin{tabular}{|c|c|c|c|c|c|}
\hline & Actividad & Descripción & Objetivo & Materiales & Tiempo \\
\hline 1 & $\begin{array}{l}\text { Juego de } \\
\text { entrada }\end{array}$ & $\begin{array}{l}\text { Se realiza el saludo y se } \\
\text { le brinda distintas } \\
\text { opciones de juegos de } \\
\text { mesa para que elija. }\end{array}$ & $\begin{array}{l}\text { Fortalecer el } \\
\text { vínculo con el } \\
\text { niño y que este } \\
\text { logre liberar la } \\
\text { ansiedad y } \\
\text { tensión } \\
\text { acumulada. }\end{array}$ & $\begin{array}{l}\text { Diversos } \\
\text { juegos de } \\
\text { mesa: } \\
\text { "Uno", } \\
\text { "Jenga", } \\
\text { "Guacamol } \\
\text { ", } \\
\text { "Pictureca" } \\
\text { "Cranium", } \\
\text { etc. }\end{array}$ & $10 \mathrm{~min}$. \\
\hline 2 & $\begin{array}{l}\text { Conversar } \\
\text { sobre su } \\
\text { semana }\end{array}$ & $\begin{array}{l}\text { Se le pregunta qué tal le } \\
\text { fue en su semana y se } \\
\text { conversa y trata de } \\
\text { encontrar soluciones } \\
\text { juntos, si es que ocurrió } \\
\text { algún incidente. Se } \\
\text { dibuja la situación y las } \\
\text { posibles opciones para } \\
\text { lograr un mejor } \\
\text { entendimiento. }\end{array}$ & $\begin{array}{l}\text { Ayudarlo a } \\
\text { buscar } \\
\text { soluciones } \\
\text { para } \\
\text { situaciones de } \\
\text { la vida diaria. }\end{array}$ & $\begin{array}{l}\text { Hojas bond } \\
\text { Lápiz } \\
\text { Colores } \\
\text { Plumones }\end{array}$ & $5 \mathrm{~min}$. \\
\hline
\end{tabular}

3 Tarjetas de Se le entrega unas Flexibilidad de Tarjetas de $10 \mathrm{~min}$ situaciones

tarjetas en la que se una pensamiento situaciones secuencia de figura que deben ser ordenas para contar una historia. El niño debe ordenarlas y luego crear una historia con ellas y contar sobre lo que paso antes $\mathrm{y}$ después.

4 Diferente $\quad$ Se le dice al niño que le Flexibilidad de Tarjetas de $10 \mathrm{~min}$ orden de la brinde un final pensamiento situaciones historia y un alternativo a su historia y luego cambie el orden 


\begin{tabular}{lllll}
\hline \multicolumn{2}{l}{$\begin{array}{l}\text { final } \\
\text { alternativo }\end{array}$} & $\begin{array}{l}\text { de las tarjetas para crear } \\
\text { otra historia corta. }\end{array}$ & & \\
Cómo se & $\begin{array}{l}\text { Se le dice que señale } \\
\text { sintió }\end{array}$ & $\begin{array}{l}\text { Reconocer e } \\
\text { con caritas cómo se } \\
\text { sintió al jugar y } \\
\text { explique el porqué. }\end{array}$ & $\begin{array}{l}\text { Lámina con } \\
\text { emociones } \\
\text { básicas }\end{array}$ & 5 min. \\
& & & \\
& & & \\
\end{tabular}

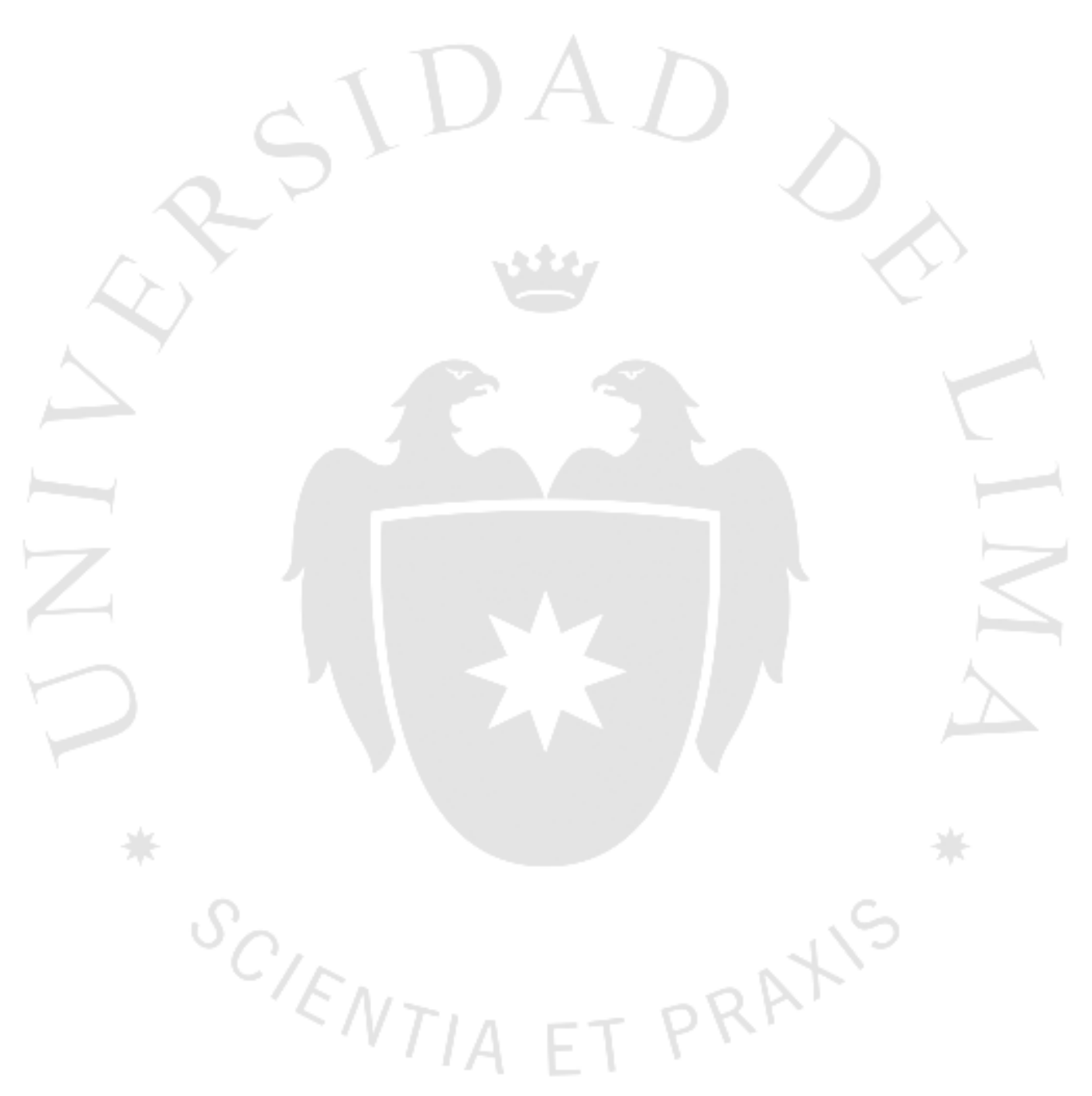




\section{DISCUSIÓN}

Se sabe que el TDAH es un trastorno que impacta en la vida diaria del que lo padece, por eso es importante una detección e intervención temprana. Un diagnóstico correcto y a tiempo es el primer paso para un buen tratamiento del trastorno y para la prevención de sus complicaciones así como para poder descartar otras patologías. Generalmente los padres, profesores, orientadores, pedagogos, o pediatras son los primeros en sospechar un posible caso de TDA-C (Soutullo y Díez, 2007.)

El proceso de evaluación del TDAH en etapas pre-escolares, debería guiarse tanto por la información brindada por las personas significativas que se encuentran en el entorno del niño, como en la valoración de las pruebas neuropsicológicas. No obstante, la observación no deja de jugar un papel importante en la diferenciación de niños disruptivos de aquellos que no lo son, evaluando la intensidad de las conductas en distintos entornos. (Casas, Gil-Llario y Jarque, 2003)

Diversas investigaciones evidencian la eficacia de un tratamiento en etapas tempranas para evitar problemas a largo plazo. A partir de este tipo de intervenciones se pueden prevenir diversos problemas escolares, sociales y emocionales que acarrea este trastorno (Presentación y Siegenthaler, 2005).

Se sabe que cada niño con TDAH es diferente y requiere de un tratamiento acorde a sus demandas y capacidades. Es por esto que es necesaria una evaluación integral desde que nace la sospecha para ir trabajando en equipo junto con la familia y profesores para brindarles las mejores oportunidades de mejora a estos niños. Mientras más pronto se trabaje tanto con los profesores como con los padres brindándoles pautas y herramientas 
específicas para el trabajo con cada niño según sus necesidades, mejor será el desenvolvimiento del niño y su pronóstico (Orjales, 2012).

Gran variedad de estudios indican que la población con TDAH presenta alteraciones en distintos componentes de funciones ejecutivas, como la inhibición de respuesta, la vigilancia, la memoria de trabajo y la planificación (Barkley, 2008). Brown identifica que dos aspectos importantes dentro de las capacidades cognitivas afectadas en el TDAH, son la motivación y la regulación de las emociones, siendo estas capacidades la base cognitiva del trastorno (Soutullo, 2007).

En cuanto al factor instrumental, Salomón presenta dificultades en su capacidad espacial, razonamiento visual para ordenar series, organización perceptiva, recepción auditiva y en la pre escritura (grafomotricidad).

"Aproximadamente la mitad de los niños con TDAH tienen problemas de aprendizaje específicos, como dislexia, trastorno de cálculo y / o trastornos de lenguaje. Estos trastornos no son provocados por el déficit, sino que están asociados a él" (Green, 2005).

Diversas investigaciones han demostrado que las funciones ejecutivas se incrementan paulatinamente a partir de los años preescolares y el mayor avance en el desarrollo se produce entre los 7 y 10 años (Pistoia et. Al, 2004), es por esto que es la mejor etapa para ayudar a los niños a desarrollar hábitos y estrategias que les sirvan para un mejor desempeño académico y social. Los aportes de la neuropsicología nos permiten reconocer la importancia de la flexibilidad cognitiva y la capacidad de moldeamiento de los niños pequeños para prevenir mayores repercusiones a largo plazo.

Según los resultados obtenidos en el proceso cognitivo básico, se observan dificultades en el área cognitiva-desatención, asociado a indicadores altos de inquietud e impulsividad. Impactando en sus relaciones sociales y en su adaptación al entorno escolar.

Se sabe que de los niños que no reciben tratamiento, un gran porcentaje termina en fracaso escolar o adicciones en la adolescencia, y divorcios o robos en la adultez. Se debe trabajar con ellos antes que presenten dificultades a nivel conductual que los marginen de la sociedad, su autoestima y autoeficacia se ven influidas, además de otras áreas de su vida (Piñedo y Benito, 2011). 
El desarrollo normal de las funciones ejecutivas es esencial para el adecuado funcionamiento cognitivo y para el desarrollo socioafectivo del niño. A medida que maduramos, vamos desarrollando la capacidad para hacer frente a situaciones nuevas y adaptarnos a los cambios de manera flexible. Las alteraciones tempranas en el desarrollo de las funciones ejecutivas limitan estas capacidades y originan una serie de consecuencias a corto, medio y largo plazo (Amador y Krieger, 2013).

Un diagnóstico e intervención temprana, derivan en un tratamiento e intervención multidisciplinaria que contribuye a un pronóstico más favorable. Es por esto que en el caso de niños como Salomón, que reúnen las siguientes características; no presentan problemas de conducta, tienen un coeficiente intelectual promedio, viven en un hogar con padres preocupados y cuentan con profesores preparados; tienen mayores posibilidades de obtener beneficios de la terapia y una mejor respuesta al tratamiento. Asimismo, al orientar a los profesores en técnicas cognitivas y conductuales, estos podrán optimizar la instrucción y desarrollar herramientas que ayuden a niños con TDAH a obtener una mejor ventaja del aprendizaje que se da en clase. Las terapias de atención concentración, habilidades sociales y psicomotricidad serán de gran ayuda para mejorar el desempeño de estos niños ante las exigencias académicas y sociales de su entorno.

De acuerdo a las investigaciones se ha demostrado que el entrenamiento de los profesores en técnicas cognitivas y conductuales, es indispensable para optimizar la instrucción y manejar el comportamiento de los niños con TDAH en el entorno escolar ya que constituye un componente esencial en la planificación de intervenciones con una alta probabilidad de éxito (Miranda y colaboradores, 2002).

Es importante que los adultos que están en el entorno del niño se encuentren informados sobre la problemática, asuman responsabilidades y se sientan comprometidos para así ayudar al niño a compensar sus dificultades y aprovechar sus talentos (Korzeniowski \& Ison, 2008).

Algunas limitaciones que se pueden encontrar al implementar estos programas es la falta de información sobre el trastorno de parte de las personas que rodean a estos niños. Muchas veces los problemas de atención o hiperactividad se confunden con engreimiento, problemas de conducta o problemas de aprendizaje y no se abordan de manera adecuada, lo que afecta el auto concepto del niño y la manera en que lo ven las personas que lo rodean. 
En el caso de Salomón, se establece el diagnostico neurológico de TDAH-C exhibiendo el mismo patrón cognitivo típico de este trastorno en la evaluación psicológica, presentando disminución significativa en la atención, déficit de la velocidad de procesamiento, baja capacidad para adquirir, conservar y recuperar conocimientos, interiorizar información de su entorno y retenerla para su uso posterior, siendo actualmente un factor de riesgo para el desarrollo de sus nuevos aprendizajes tanto sociales como académicos.

Asimismo presenta dificultades en la psicomotricidad y torpeza motriz que también se observa en la literatura (Vidarte, Ezquerro y Giráldez, 2009) pero no en tan alta medida como en el presente caso. Según este autor, se sabe que los niños con TDAH presentan una capacidad motora menor que otros niños sin el trastorno, pero dentro del promedio. De acuerdo a su perfil individual, Salomón presenta una capacidad psicomotora muy inferior al promedio, lo que afecta sus procesos de aprendizaje de preescritura, además de alteraciones espaciales, invirtiendo números y letras. Sin embargo, como dice la literatura ésta ha mejorado comparando ambas fases de evaluación.

Asimismo, a nivel personal como se pronostica en investigaciones previas (Parellada, 2009), Salomón evidencia alteraciones sociales, afectivas y de comportamiento en la escuela debido a su impulsividad, falta de perseverancia, baja tolerancia a la frustración, dificultad en el manejo del tiempo, desorganización e inmadurez emocional. Esto impacta en la percepción de sus compañeros y maestros, dando la impresión de desobediente u oposicionista al no realizar las actividades que se le indican o al imponer sus reglas y orden de juego.

El TDAH y el síndrome de asperger, son dos condiciones distintas e independientes que, sin embargo, presentan coincidencias en algunos de sus síntomas, lo que en ocasiones pueden generan confusiones entre padres y educadores e incluso errores en el diagnóstico. Estas dificultades para diferenciar ambos diagnósticos se dan durante los primeros años de vida dada la similitud de las síntomas: dificultad para interpretar y entender los sentimientos de los demás, problemas de atención, conductas hiperactivas y, en ocasiones, también compulsivas y dificultades de autocontrol y autorregulación de la conducta. (Universidad Internacional de Valencia, 2015)

Al inicio de la evaluación sus niveles de atención e interés social eran tan bajos que se sospechó de un trastorno del desarrollo, se encontraba inmerso en su propio mundo 
y le costaba socializar con otras personas si es que éstas no llamaban su atención y presentaba movimientos estereotipados. Mediante una evaluación neurológica y un diagnóstico diferencial, se descartó esta sospecha y se atribuyó estas dificultades a sus bajos niveles de atención e impulsividad. Actualmente, comparando ambas fases de evaluación y teniendo en cuenta el trabajo terapéutico interdisciplinario realizado en etapas tempranas previo a la segunda fase, se han visto han mejoras a nivel social, logrando interactuar y conectarse con otras personas de su entorno de manera voluntaria, inclusive buscando la aceptación social. Es capaz de leer señales sociales y expresiones faciales sin dificultad. Asimismo, sus conductas estereotipadas han disminuido notablemente y se muestra más flexible al cambio. Lo que confirma que el problema central en Salomón es su déficit de atención con hiperactividad.

Es por esto que se propone la aplicación de programas preventivos en casos de niños con TDAH, en los que se busque trabajar en equipo interdisciplinario para reforzar las habilidades cognitivas, emocionales y sociales del niño y ayudarlo a fortalecer sus recursos personales e interpersonales, para que se sienta acogido y validado dentro de su entorno. Para esto se debe partir de la identificación del perfil de dificultades y fortalezas, seleccionando las competencias a trabajar a través de la aplicación de estrategias innovadoras como la rehabilitación de las funciones ejecutivas, neuropsicológica y ejercicios de flexibilidad cognitiva.

Al momento de evaluar se debe utilizar técnicas conductuales como refuerzos al finalizar las tareas, descansos y premios para motivar y centrar la atención del niño con TDAH evitando que se agote y que los resultados de la evaluación se invaliden. De esta forma se tendrá una presunción diagnóstica más acertada y acorde al caso, sin sobre estimar las capacidades del niño.

Es importante contar con instrumentos validados en nuestra realidad siendo pertinentes la Escala Conners, el inventario de conducta pre escolar y escolar, para descartar un posible TDAH.

Además, es importante derivar al niño a una interconsulta neurológica para confirmar el diagnóstico y considerar que tanto está afectando su déficit a nivel académico y si necesitaría de la ayuda de la medicación. Asimismo, este ayudará a descartar otros diagnósticos comórbidos, lo que decidirá la dirección que toma el tratamiento. 
Un diagnostico acertado y a tiempo brindó estrategia tanto a los padres de Salomón como a los maestros que lo ayudaron a mejorar a nivel académico, trabajando su psicomotricidad, atención-concentración, control de impulsos y habilidades sociales. Actualmente sus tiempos de atención son más largos y se mantiene enfocado en tareas cortas hasta finalizarlas. Asimismo, ha logrado establecer relaciones significativas con otros y participar de los juegos grupales sin necesidad de un adulto mediador.

Este trabajo interdisciplinario, adaptando estrategias y capacitando a las personas involucradas en la crianza, ha ayudado a prevenir futuros problemas de académicos como repitencia, sociales y de autoestima en él, resultando en un niño más conectado con su entorno y con mayor autoeficacia. 


\section{CONCLUSIONES}

- Es importante una detección temprana del TDAH para prevenir futuras complicaciones o repercusiones en la vida diaria del que padece este trastorno, realizando un diagnóstico diferencial; padres, profesores, orientadores, pedagogos o pediatras son los primeros en sospechar un posible caso de TDA-C.

- Cada caso de TDAH es único y por lo tanto, requiere de un tratamiento acorde a sus demandas y capacidades, para ello es necesaria una evaluación integral en la que se trabaje junto a la familia y profesores brindándoles pautas y herramientas específicas según el perfil del caso y su entorno.

- Es importante que la escuela y la familia se encuentren informados sobre el trastorno para que asuman responsabilidades y se sientan comprometidos, y así ayudar al niño a compensar sus dificultades y aprovechar sus talentos.

- Por lo tanto, para mejorar el abordaje de los niños con TDAH es necesario el entrenamiento de los profesores en técnicas cognitivas-conductuales.

- Dada la importancia de la prevención en la intervención con niños con TDAH, se debe trabajar las funciones ejecutivas disminuidas ya que a la edad de 7 a 10 años, esta es la mejor etapa para desarrollar hábitos y estrategias que le sirvan a los niños para lograr un mejor desempeño académico y social.

- Si no se trabaja en equipo y de forma preventiva, se observa que un gran porcentaje de estos niños presentan fracaso escolar o adicciones en la adolescencia, y divorcios o robos en la adultez.

- El presente caso es típico de un TDAH-C que se muestra en la literatura, con una disminución significativa la velocidad de procesamiento, atención, impulsividad e inquietud, asociado a baja capacidad espacial, recepción auditiva, organización perceptiva y grafomotricidad.

- Tal como se ve en el presente caso, los niños con TDAH a nivel personal denotan alteraciones sociales, afectivas y de comportamiento en la escuela debido a su impulsividad, falta de perseverancia, baja tolerancia a la frustración, dificultad en el manejo del tiempo y desorganización; sin embargo, gracias al trabajo terapéutico interdisciplinario se puede lograr una mejora en la interacción y conexión con otras personas de su entorno, incluso buscando la aceptación social. 
- Para estos casos se propone la aplicación de programas preventivos identificando el perfil de dificultades y fortalezas, seleccionando las competencias a trabajar a través de la aplicación de estrategias como la rehabilitación de las funciones ejecutivas, la neuropsicología y ejercicios de flexibilidad cognitiva.

- Se debe utilizar técnicas cognitivo-conductuales como refuerzos para motivar y enfocar la atención del niño así como una interconsulta multidisciplinaria para confirmar el diagnóstico y validar el uso de medicación como ayuda.

- Es importante la validación de pruebas en el ámbito nacional para contar con estándares acordes a nuestra realidad. 


\section{RECOMENDACIONES}

A continuación detallaremos las recomendaciones:

- Realizar un diagnóstico temprano de forma multidisciplinaria en casos de TDAH.

- Contar con instrumentos validados en nuestra realidad siendo pertinentes la Escala Conners, el inventario de conducta pre escolar y escolar, entre otros.

- Realizar un seguimiento cada 6 meses de los avances del niño para ir modificando el tratamiento.

- Instruir periódicamente a padres y maestros en el manejo de las estrategias de intervención del TDAH

- Planificar pequeños objetivos, que sean claros y secuenciados.

- Aplicar estrategias cognitivo conductuales para desarrollar su autocontrol, como autoinstrucciones para cada tarea.

- Trabajar estrategias metacognitivas para ayudarlo a reflexionar sobre su conducta y las consecuencias de esta.

- Dar órdenes claras, cortas y concretas.

- Desarrollar estrategias de habilidades sociales fomentando espacios de interacción con otros niños al asistir a actividades extracurriculares o al aire libre.

- Brindar incentivos, utilizar sistema de puntos, siempre ha de haber consecuencias inmediatas.

- Contar con planificadores para determinar las tareas inmediatas y mediatas. 


\section{REFERENCIAS}

Alcalde, B. (2004). Psicoterapia psicoanalítica y TDAH. Artículo publicado en el boletín electrónico $\mathrm{n}^{\mathrm{o}} 5$ del APDA. Recuperado el 25 de Febrero del 2015 de http://deficitdeatencionperu.com/psicoterapia-psicoanalitica-y-tdah.html

American PsychiatricAssociation. (2014). Guía de consulta de los criterios diagnósticos del DSM-5. American psychiatricpublishing. Washington, DC. 438 p.

Anónimo (2011). Comorbilidad en niños 2011. IntitutoHermilioValdizan. Recuperado el 11 de febrero del 2014 de http://www.hhv.gob.pe/servicios/dptoninos.html

Barbudo, T. (2012). Comparación de dos escalas para evaluar TDAH por profesores. Tesis elaborada para obtener el grado de Maestra en Investigación Educativa, Yucatán. Recuperado el 27 de enero del 2015 de http://posgradofeuady.org.mx/wpcontent/uploads/2013/04/Barbudo-Tania-MIE-2012.pdf

Bauermeister, J.J. y Matos, M. (2011). El TDAH en preescolares: validez, diagnóstico, prevención y tratamiento. Apuntes de Psicología, 29, 205-225. Recuperado el 2 de diciembre $\quad$ del $2014 \quad$ de http://www.apuntesdepsicologia.es/index.php/revista/article/view/195

Casas, M., Gil Llario, M., Jarque, S. (2003). Evaluación e intervención en niños preescolares con manifestaciones de trastorno por déficit de atención con hiperactividad y conducta disruptiva. Revista de neurología, ISSN 0210-0010, Vol. 36, $\mathrm{N}^{\mathrm{o}}$ Extra 1, pág. 85. Recuperado el 28 de mayo del 2015 de http://dialnet.unirioja.es/servlet/articulo?codigo $=4658319$.

Children and AdultswithAttention-Deficit/HyperactivityDisorder (CHADD). (2004). Tratamiento conductual para los niños y adolescentes con TDA/H (WWK 7 versión corta). Recuperado el 09 de Setiembre del 2014 de http://help4adhd.org/es/treatment/behavioral/WWK7S

Conner's, K. (2004). Conners`Rating Scales- Revised. Technical Manual. MHS. Canadá. 220 pág. 
De la Peña, F. (Agosto, 2009). El Trastorno por Déficit de Atención con Hiperactividad (TDAH) en México y Latinoamérica: Avances y retos para el diagnóstico, tratamiento y la investigación.

Delgado, I. y colaboradores. (2012). Intervención Multimodal del TDAH: El papel coterapéutico de la familia. Revista Argentina de Clínica y psicología. Vol. XXI.

Filomeno, A. (Febrero, 2009). El niño con déficit de atención o hiperactividad, cómo pasar del fracaso al éxito. Universidad Cayetano Heredia, Segunda Edición, 204 p. Lima.

Fundación CADAH. Intervención psicológica en el TDAH. Recuperado el 29 de abril del 2014 de http://www.fundacioncadah.org/web/articulo/intervencion-psicologicae-el-tdah.html

Fundación CADAH. Diferencias y similitudes entre TDAH y Síndrome de Asperger. Recuperado el 15 de setiembre del 2015 de http://www.fundacioncadah.org/web/articulo/diferencias-y-similitudes-entre-tdahy-sindrome-de-asperger.html

Gómez, M. (2006). Papel del pediatra de atención primaria en la atención integral al niño y adolescente con trastorno por déficit de atención e hiperactividad (TDAH). Foro pediátrico. Recuperado el 20 de junio del 2014 de http://www.spapex.es/pdf/tdah.pdf

Green, C. (2001). El niño muy movido o despistado. Entender el trastorno por déficit de atención con hiperactividad (TDAH). Ediciones Medici. Barcelona. 369 pg.

Hammil, D., Pearson, N. y Voress, J. (1966). DTVP-2 Método de evaluación de la percepción visual de Frostig. Editorial El Manual Moderno, S.A. México, D.F. 66 pág.

Herranz, J.L. y Argumoza. A. (2000). Trastorno con déficit de atención e hiperactividad. Boletín Pediátrico 40:88-92.

Instituto Peruano de lenguaje y aprendizaje. (Octubre, 2012). TDAH en población infantil peruana es del 5\%. Recuperado el 9 de abril del 2014 de http://www.imlaperu.com/noticias_contenido.php?idPagina $=285$ 
Lavinge, R. y Romero, J. (2012). El TDAH, ¿Qué es?, ¿Qué lo causa?, ¿Cómo evaluarlo y tratarlo? Ediciones Pirámide. Madrid. 259 pg.

Martínez Carazo, M (Mayo, 2006). El método de estudio de caso: Estrategia metodológica de la investigación científica. Pensamiento \& gestión, 20. Universidad del Norte, 165-193. Recuperado el 29 de abril del 2014 de http://ciruelo.uninorte.edu.co/pdf/pensamiento_gestion/20/5_El_metodo_de_estudi o_de_caso.pdf

Mayes, S. D., \& Calhoun, S. L. (2007). Learning, Attention, Writing, and Processing Speed in Typical Children and Children with ADHD, Autism, Anxiety, Depression, and Oppositional-Defiant Disorder. Child Neuropsychology, 13(6), 469-493.

Miller, C. (2014). Terapia Conductual para Niños con TDAH Cómo ayudar a los niños a organizarse y a controlar los comportamientos problemáticos. Recuperado el 09 de setiembre del 2014 de http://www.childmind.org/en/posts/articles/2014-3-27terapia-conductual-ninos-tdah.

Miranda A., García R., Presentación M.J. (2002). Factores moduladores de la eficacia de una intervención psicosocial en niños con trastorno por déficit de atención con hiperactividad. REV NEUROL; 34 (Supl 1): S91-S97. Recuperado el 28 de mayo de 2015

de http://www.jmunozy.org/files/9/Necesidades_Educativas_Especificas/hiperactivostdah/documentos/Intervencion_psicosocial_en_ninos_con_TDAH_Ana_Miranda_ Casas.pdf

Montiel-Nava, C. y colaboradores (2002). Estimaciones de la prevalencia del trastorno por déficit de atención-hiperactividad en niños marabinos. Revista Neurológica. Recuperado el 8 de Abril del 2014 de

http://neurologiavenezuela.org/i/imagenes/descargables/articulos\%20medicos/2012 /prevalencia1.pdf

Montiel-Nava, C., Peña, J.A., Montiel-Barbero, I (2003). Datos epidemiológicos del trastorno por déficit de atención con hiperactividad en una muestra de niños marabinos. Revista Neurológica. Recuperado el 8 de abril del 2014 de http://tdahlatinoamerica.org/documentos/articulosnuevos/prevalencia2.pdf 
Mulas, F. (2012). TDAH PREESCOLAR: Diagnóstico e intervención terapéutica Ponencia presentada XIV Curso Internacional de Neuropediatría y Neuropsicología Infantil. Valencia. Recuperado el 2 de diciembre del 2014 de http://www.invanep.com/tdah-preescolar-diagnostico-e-intervencionterapeutica.html.

Orjales, I. (2012). TDHA: origen y desarrollo. Instituto Tomás Pascual para la nutrición y salud. Madrid. Pág. 99.

Orjales, I. y Polaino-Lorente, A. (2001), Programas de Intervención Cognitivoconductual para niños con Déficit de Atención con Hiperactividad. CEPE.

Palacio, J. y colaboradores. (Agosto, 2009). Algoritmo de Tratamiento Multimodal para Preescolares Latinoamericanos con Trastorno por Déficit de Atención con Hiperactividad (TDAH). Salud Mental. Vol. 32, Supl. 1. Medellín, Colombia. Recuperado el $01 \quad$ de diciembre del 2014 de http://www.medigraphic.com/pdfs/salmen/sam-2009/sams091b.pdf

Parellada, M.J. y colaboradores. (2009). TDAH. Trastorno por déficit de atención e hiperactividad. De la infancia a la edad adulta. Madrid, Alianza Editorial, 422 pp.

Papapzian, O. Alfonso, I. y Araguez, N. (2009). Entrenamiento de la función ejecutiva en preescolares con trastorno por déficit de atención/hiperactividad combinado: estudio prospectivo, controlado y aleatorizado. Revista de Neurología; 48 SUPL. 2 Pág. 119-122. Recuperado el 01 de diciembre del 2014 de http://europa.sim.ucm.es/compludoc/AA?articuloId=708137

Piñeiro, B., Benito, R. (2011). El Trastorno por Déficit de Atención e Hiperactividad. Evolución a lo largo/de la vida y sus comorbilidades. Draft Editores, S.L. Recuperado el 09 de setiembre del 2014 de http://www.psiquiatria.com/medikinet/docs/libro_curso_TDAHadulto.pdf

Pliszka, S., (Junio, 2006). El TDAH y sus trastornos comórbidos, Steven Pliszka, M.D. Boletín electrónico $\mathrm{n}^{\mathrm{o}} 12$ del APDA. Recuperado el 9 de abril del 2014 de http://deficitdeatencionperu.com/el-tdah-y-sus-trastornos-comorbidos.html

Presentación, M.J., Siegenthaler, R., Jara, P. y Miranda, A. (2010). Seguimiento de los efectos de una intervención psicosocial sobre la adaptación académica, emocional y 
social de niños con TDAH. Psicothema 2010. Vol. 22, nº 4, pp. 778-783. Recuperado el 17 de abril del 2015 de http://www.psicothema.com/pdf/3801.pdf

Puentes, P., y colaboradores. (2014). Déficit en habilidades sociales en niños con Trastorno por Déficit de Atención-Hiperactividad, evaluados con la escala BASC. Revista Colombiana de Psicología, 23(1), 95-106. Recuperado el 16 de abril del $2015 \mathrm{de}$ http://www.redalyc.org/articulo.oa?id=80431219005

Querol, S. y Chavez, M. (2005). Test de la persona bajo la lluvia: Adaptación y aplicación. Lugar editorial. Buenos Aires. Recuperado el 20 de junio del 2014 de http://mmhaler.files.wordpress.com/2013/04/la-persona-bajo-la-lluvia-test.pdf

Quintanar, L. Gómez, R. Solovieva, Y. Bonilla, M. (2011). Características neuropsicológicas de niños preescolares con trastorno por déficit de atención con hiperactividad. Revista CES Psicología ISSN 2011-3080 Volumen 4 Número 1. Pág. 16-31. Recuperado el 01 de diciembre del 2014 de http://revistas.ces.edu.co/index.php/psicologia/article/view/1356

Ramos, J. (2005). Trastorno por déficit de atención e hiperactividad (TDAH). $\begin{array}{lllllll}\text { Recuperado el de } & 24 & \text { enero } & \text { del } & 2015 & \text { de }\end{array}$ http://www.neuroclassics.org/TDAH/TDAH.htm\#SÍNTOMAS_PRINCIPALES.

Reynolds, C.R. y Kampaus, R.W. (1998). Sistemas de evaluación de la conducta de niños y adolescentes (c). Recuperado el 20 de enero del 2015 de http://www.libreriaimagina.com/tests/basc-juego-completo.

Rigau, E. García C. Artigas J. (2006). Tratamiento del trastorno oposicionista desafiante. Rev neurológica, 42 (Supl 2). Recuperado el 20 de junio del 2014 de http://www.psicodiagnosis.es/areaclinica/trastornosdeconducta/trastornonegativista desafianteporoposicion/index.php

Rodríguez, L. y colaboradores (Junio, 2009). Estudio psicométrico-clínico de prevalencia y comorbilidad del trastorno por déficit de atención con hiperactividad en Castilla y León (España). Revista Pediatría Atención Primaria v.11 n.42. Recuperado el 11 de febrero del 2014 de http://scielo.isciii.es/scielo.php?pid=S1139$\underline{76322009000200006 \& \text { script }=\text { sci_arttext }}$ 
Servera-Barceló, M. (2005). Modelo de autorregulación de Barkley aplicado al trastorno por déficit de atención con hiperactividad: una revisión. Rev. Neurológica; 40(6):358-368

Shanahan, M. A., Pennington, B. F., Yerys, B. E., Scott, A., Boada, R., Willcutt, E. G., DeFries, J. C. (2006). Processing Speed Deficits in Attention Deficit/Hyperactivity Disorder and Reading Disability. Journal of Abnormal Child Psychology, 34(5), 584-601.

Solovieva, Y. Lázaro, E. Quintanar, L. (2008). Mecanismos de los lóbulos frontales en niños preescolares con déficit de atención y niños normales. Acta Neurológica. Colombia. Pág. 64-75. Recuperado el 01 de Diciembre del 2014 de http://www.acnweb.org/acta/2008_24_S2_64.pdf.

Tannock, R., Martinussen, R., \& Frijters, J. (2000). Naming Speed Performance and Stimulant Effects Indicate Effortful, Semantic Processing Deficits in AttentionDeficit/Hyperactivity Disorder. Journal of Abnormal Child Psychology, 28(3), 237252.

Tirapu J. (2007). La evaluación neuropsicológica. Intervención Psicosocial v.16 n.2 Madrid. Recuperado el 26 de enero del 2015 de http://scielo.isciii.es/scielo.php?script=sci_arttext\&pid=S1132$\underline{05592007000200005}$

Universidad Internacional de Valencia. 2015. Similitudes y diferencias entre los síntomas de TDAH y síndrome de Asperger. Recuperado el 14 de setiembre del 2015 de http://www.viu.es/blog/similitudes-y-diferencias-entre-los-sintomas-de-tdah-ysindrome-de-asperger/

Vidarte, J.A., Ezquerro, M., Giráldez, M.A. (2009). Perfil psicomotor de niños de 5 a 12 años diagnosticados clínicamente de trastorno por déficit de atención/hiperactividad en Colombia. REV NEUROL; 49: 69-75 Recuperado el 16 de abril del 2015 de http://www.neurologia.com/pdf/web/4902/bc020069.pdf.

Weiler, M. D., Bernstein, J. H., Bellinger, D. C., \& Waber, D. P. (2000). Processing Speed in Children With Attention Deficit/Hyperactivity Disorder, Inattentive Type. Child Neuropsychology, 6(3), 218-234. 
ANEXOS

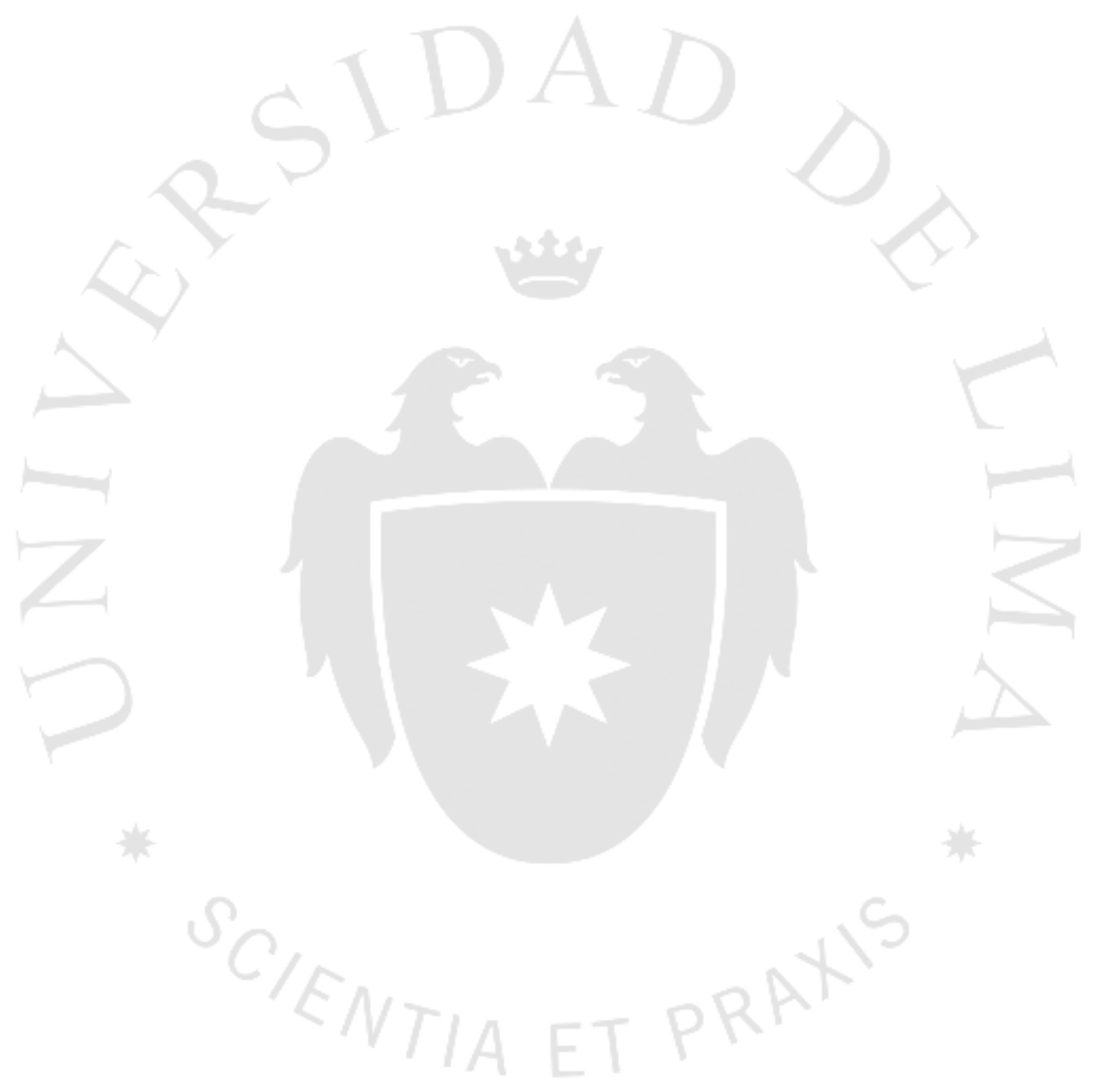

